\title{
WestVirginiaUniversity
}

THE RESEARCH REPOSITORY @ WVU

Graduate Theses, Dissertations, and Problem Reports

2019

\section{Three Essays on the Economics of Public Libraries}

Amir Borges Ferreira Neto

West Virginia University, amneto@mix.wvu.edu

Follow this and additional works at: https://researchrepository.wvu.edu/etd

Part of the Labor Economics Commons, Other Economics Commons, Public Economics Commons, and the Regional Economics Commons

\section{Recommended Citation}

Ferreira Neto, Amir Borges, "Three Essays on the Economics of Public Libraries" (2019). Graduate Theses, Dissertations, and Problem Reports. 3924.

https://researchrepository.wvu.edu/etd/3924

This Dissertation is protected by copyright and/or related rights. It has been brought to you by the The Research Repository @ WVU with permission from the rights-holder(s). You are free to use this Dissertation in any way that is permitted by the copyright and related rights legislation that applies to your use. For other uses you must obtain permission from the rights-holder(s) directly, unless additional rights are indicated by a Creative Commons license in the record and/ or on the work itself. This Dissertation has been accepted for inclusion in WVU Graduate Theses, Dissertations, and Problem Reports collection by an authorized administrator of The Research Repository @ WVU.

For more information, please contact researchrepository@mail.wvu.edu. 


\title{
Three Essays on the Economics of Public Libraries
}

\author{
Amir Borges Ferreira Neto \\ Dissertation submitted to the \\ College of Business and Economics \\ at West Virginia University \\ in partial fulfillment of the requirements \\ for the degree of \\ Doctor of Philosophy \\ in \\ Economics \\ Joshua C. Hall, Ph.D., Chair \\ Brad R. Humphreys, Ph.D. \\ Adam D. Nowak, Ph.D. \\ Peter V. Schaeffer, Ph.D. \\ Department of Economics \\ Morgantown, West Virginia \\ 2019
}

Keywords: Public Libraries, Government, Donation, Local Labor Market, Efficiency

Copyright 2019 Amir Borges Ferreira Neto 


\begin{abstract}
Three Essays on the Economics of Public Libraries
\end{abstract}

\title{
Amir Borges Ferreira Neto
}

This dissertation explores empirical issues concerning public libraries in the United States. In particular, it analyzes the direct and indirect effects to and from public libraries, on different issues such as charitable donations, labor market outcomes, institutions and technical efficiency. Chapter 1 discusses the economics of public libraries and its relevance. In addition, it provides an outline of the dissertation and its main contribution to the literature. Chapter 2, analyzes the determinants of donations to public libraries testing the crowding effect from government funding of public libraries. I find suggestive results of a crowd in effect with an inverted $U$ shape in all levels of government. In other words, additional government dollars increase private donations to public libraries at a decreasing rate. Chapter 3 investigates the effect of public library programs and participation on unemployment and labor force participation in Appalachia. Using an instrumental variable approach, I show that neither adult nor children's programs and participation affect local labor market outcomes. These results are robust across different specifications. Chapter 4 explores the institutional determinants of public library technical efficiency in West Virginia. The analysis is carried out in two steps. First, I document considerable cross-district variation in library efficiency. Then, I estimate the effect of institutional characteristics on the technical efficiency measures. I find consistent evidence that urban libraries are more inefficient than county and multi-jurisdictional libraries. In addition, I find revenue from local sources is associated with reduced efficiency, contrary to what would be predicted by local public goods producer theory. Chapter 5 concludes the dissertation by summarizing its main findings and discussing possible implications. 


\section{Acknowledgements}

I would like to thank the people who have been influential on my development over the last five years at West Virginia University. To my advisor, Dr. Joshua Hall, to whom I owe so much, thank you for all the opportunities, mentoring, guidance and advice at all times; most importantly, thanks for believing in me. You are a big part of my development as a scholar.

To Dr. Randall Jackson, I would like to thank for all the opportunities and guidance. My time at the RRI under your supervision has been crucial to development as researcher and scholar. Also, I would like to thank the RRI, especially Doris and Caigan, who have been like family since my arrival at WVU. I could not have asked for a better environment to pursue my goals.

I am also grateful to have had great faculty who shared their love for economics, and provided me with so much support; in particular, Dr. Brad Humphreys, Dr. Adam Nowak, Dr. Amanda Ross and Dr. Peter Schaeffer. I would not have considered pursuing my PhD if not for the encouragement of Dr. Fernando Perobelli, Dr. Ricardo Freguglia, Dr. Suzana Quinet, Dr. Eduardo Haddad and Dr. Rodrigo Zeidan.

To the friends WVU has given me, thank you for the support during this process. Your friendship made my PhD journey a lighter one. In particular, I would like acknowledge Juliana, João, Caleb, Elham, Patrick, Franny, Pyun, Yang, Alex, Riss, Eddie, Tiff, Iuri and Jamie. Thank you!

To my parents, Amir and Valéria, and my siblings, Daniel and Raquel, thank you for the love, motivation, patience and help. I would not be here today if not for you.

Finally, this journey and its outcome would not have been as special and important if not for my wife, Izabella. You have embraced my dream, and provided me with unwavering support, patience, love and the utmost encouragement. There is no one else I would like by my side right now. I dedicate this dissertation to you. I love you! 


\section{Contents}

$\begin{array}{ll}\text { Acknowledgements } & \text { iii }\end{array}$

List of Figures $\quad$ vi

List of Tables $\quad$ vii

1 Introduction 1

1.1 The Economics of Public Libraries _. . . . . . . . . . . . . . . . 1

1.1.1 Public Library in the US . . . . . . . . . . . . . . . . . 1

1.1.2 Previous Studies on Public Library . . . . . . . . . . . . . . . 3

1.2 Contributions and Outline . . . . . . . . . . . . . . 4

2 Charity and Public Libraries: Does Government Funding Crowd Out Do$\begin{array}{ll}\text { nations? } & 7\end{array}$

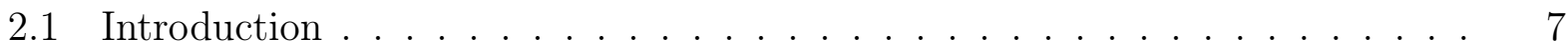

2.2 Methodological Approach _.. . . . . . . . . . . . . . . . . . . . . 10

2.3 Data . . . . . . . . . . . . . . . . . . . . . . 13

2.4 Results . . . . . . . . . . . . . . . . . . . . . . . . . . . . 15

2.4 .1 Robustness Check . . . . . . . . . . . . . . . . . . . . 17

2.5 Conclusion and Implications $\ldots \ldots \ldots \ldots$

3 Do Public Libraries Impact Local Labor Markets? Evidence from Appalachia 26

3.1 Introduction . . . . . . . . . . . . . . . . . 26

3.2 Background . . . . . . . . . . . . . . . . . . . . . . 31

3.2 .1 Public Library in the US . . . . . . . . . . . . . . . . . . . . 31

3.2 .2 Active Labor Market Programs . . . . . . . . . . . . . . . . . . 32

3.3 Data . . . . . . . . . . . . . . . . . . . . . . . . . . 33

3.3.1 Labor Market Outcomes . . . . . . . . . . . . . . . . . . . . 33

3.3 .2 The Public Library Survey . . . . . . . . . . . . . . . . . . . . 34

3.3.3 Demographic and Industry Characteristics . . . . . . . . . . . . . 35

3.4 Empirical Strategy . . . . . . . . . . . . . . . . . . . . . . . 36

3.4 .1 Instrument Validity . . . . . . . . . . . . . . . . . . . . . 38

3.5 Results . . . . . . . . . . . . . . . . . . . . . . . . . . . 40

3.5.1 Robustness Checks . . . . . . . . . . . . . . . . . . . . . 41 
3.5.2 Spatial Spillovers . . . . . . . . . . . . . . . . . 44

3.6 Conclusion and Policy Implication . . . . . . . . . . . . . . . . . . . 47

4 Economies of Scale and Governance of Library Systems: Evidence from West Virginia

64

4.1 Introduction . . . . . . . . . . . . . . . . . . . . . . . 64

4.2 Empirical Strategy . . . . . . . . . . . . . . . . . . . . . . 67

4.2.1 The Public Library Survey . . . . . . . . . . . . . . . . . . . . . . . . . . . . . . 67

4.2.2 Measuring Technical Efficiency . . . . . . . . . . . . . 67

4.2.3 Technical Efficiency Results for West Virginia Libraries . . . . . . . . 69

4.3 Explaining Technical Efficiency . . . . . . . . . . . . . . . . . 70

4.4 Discussion and Implications . . . . . . . . . . . . . . . . . . 73

5 Concluding Remarks $\quad 82$

6 Appendices $\quad 84$

6.1 Appendices to Chapter 2 . . . . . . . . . . . . . . . 85

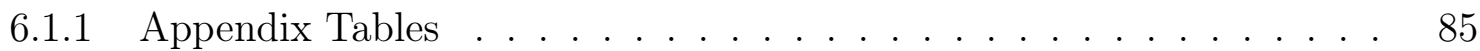

6.1.2 Instrumental Variable Approach . . . . . . . . . . . . . . . . . 86

6.2 Appendix to Chapter $4 \ldots \ldots \ldots$. . . . . . . . . . . . . . 90 


\section{List of Figures}

2.1 Scatterplot of Donations and Government Revenues with and without outliers 25

3.1 The Appalachia Region . . . . . . . . . . . . . . . . . . . . 58

3.2 Number of Libraries per County for the US . . . . . . . . . . . . . . . . . 59

3.3 Number of Adults and Children Program in 2006 . . . . . . . . . . . . . 60

3.4 Number of Adults and Children Program in 2015 . . . . . . . . . . . . . . . 61

3.5 Quantile Regression Results using OLS . . . . . . . . . . . . . . . . 62

3.6 Quantile Regression Results using Predicted Values . . . . . . . . . . . . 63

4.1 Scale Efficiency by Inputs . . . . . . . . . . . . . . . . . . . . . . . . 81 


\section{List of Tables}

2.1 Descriptive Statistics . . . . . . . . . . . . . . . . . . . 21

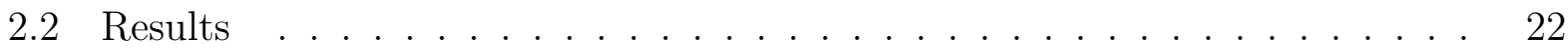

2.3 Results in per capita values . . . . . . . . . . . . . . . . . . 23

2.4 Outliers Results . . . . . . . . . . . . . . . . . . . 24

3.1 Summary Statistics for Local Labor Market Outcome Variables . . . . . . . 49

3.2 Descriptive Statistics . . . . . . . . . . . . . . . . . . . 50

3.3 Exclusion Restriction for Books and Masters . . . . . . . . . . . . . . 51

3.4 First Stage Results for Adults and children's programs . . . . . . . . . . . . 52

3.5 Results for Library Programs and Participation on Unemployment Rate and Labor Force Participation Rate . . . . . . . . . . . . . . . . . . . . . . 53

3.6 Exogenous Shock Results for Library Programs and Participation on Unemployment Rate and Labor Force Participation Rate . . . . . . . . . . . . . . 54

3.7 Comparison of Means Between Groups . . . . . . . . . . . . . . . . . . . 55

3.8 Propensity Matching Results for Library Programs and Participation on Unemployment Rate and Labor Force Participation Rate . . . . . . . . . . . . . 56

3.9 Spatial Dependence and Spillovers of Library Program and Participation . . 57

4.1 Descriptive Statistics by Governance . . . . . . . . . . . . . . . . . . . 75

4.2 Inputs and Outputs for DEA . . . . . . . . . . . . . . . . . 76

4.3 Descriptive Statistics for Technical Efficiency . . . . . . . . . . . . . . . 77

4.4 Control Variables . . . . . . . . . . . . . . . . . . . . . . 78

4.5 Least Square Results . . . . . . . . . . . . . . . . . . . . . . . . . . 79

4.6 Fractional Logit Results . . . . . . . . . . . . . . . . . . 80

6.1 Variables description ....................... . . 85

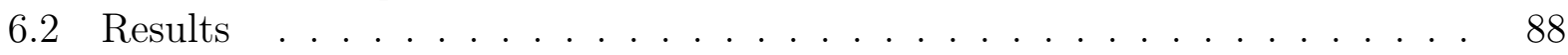

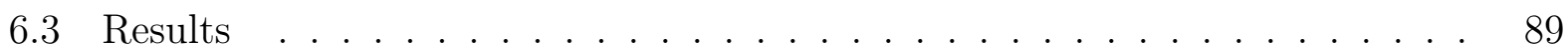

6.4 Average TE by Library . . . . . . . . . . . . . . . . . . . . . . . . . . 90 


\section{Chapter 1}

\section{Introduction}

\subsection{The Economics of Public Libraries}

\subsubsection{Public Library in the US}

Public libraries in the US started as privately financed institutions that offered booklending services. The first of these institutions was the Philadelphia Library Company founded in 1731 with the help of Benjamin Franklin. Even though these libraries were privately funded, the government would still support them occasionally. By 1850, there were almost 700 out of these type of public libraries in the country. The Boston Public Library, founded in 1852, is the first to be part of the local government budget. The expansion of public libraries was facilitated by donations of Andrew Carnegie, who helped fund the construction of over 1,500 public libraries in the US alone, which represents around $15 \%$ of current public libraries in the country. However, the funds provided by Mr. Carnegie were to support the construction only, and not to be used in the endowment of these libraries. This feature of Mr. Carnegie support led local governments into the public libraries business (Getz, 1980; Wiegand, 2015).

Public libraries have been, and still are valued by its patrons ${ }^{1}$ (Wiegand, 2015). This is especially true for black and hispanic patrons, as well as students, job seekers and those without internet access at home (Pew Research Center, 2013b, 2014). However, a study

\footnotetext{
${ }^{1}$ Walker (2017) and Mourdoukoutas (2018) show evidence of current (passionate) discussion on the subject.
} 
by the Pew Research Center (2014) shows that educated and high income people are more likely to use public library services. This is also true for parents, especially mothers (Pew Research Center, 2013c, 2014). Nevertheless, there is a lack of knowledge of the services public libraries offer (Pew Research Center, 2013b,a; Rainie, 2016).

According to the Pew Research Center (2013b; 2013a, Horrigan 2015) library users want public libraries to: support local education, coordinate [programs] with local schools, provide free literacy program for young children, help local business and job seekers, embrace new technologies and help patrons to learn new high technologies gadgetry, among others. Currently, over $92 \%$ of public libraries offer employment support programs such as job database, assistance to job applications, and help with employment materials like resumé creation; $44 \%$ offer some formal technology training, while $83 \%$ offer informal training (Bertot et al., 2012). Further, Rainie (2016) reports other programs such as general education development (GED) preparation and high school equivalence programs, starting new business programs, online programs of certification of mastering new skill, among others. However, little investigation on the effectiveness of such programs exists.

Some recent figures on public libraries show that, in 2014, public libraries had a total of 1.4 billion in-person visits (4.6 visits per capita) a decrease of $2.4 \%$ from 2013. In terms of finance, public libraries received a total of $\$ 12.6$ billion ( $\$ 39.34$ per capita) in operating revenues, from which $85.2 \%$ are from local governments, $7.0 \%$ from state government, $0.4 \%$ from federal government and $7.4 \%$ from other sources like fees, grants and donations. The operating expenditures totaled $\$ 11.9$ billion ( $\$ 36.96$ per capita). Further, in terms of locale, $23.3 \%$ of libraries are considered rural libraries; from the urban libraries, most of them are in the suburbs (30.3\%), followed by city $(27.0 \%)$ and town (19.5\%). Lastly, the share of resources in 2014 (2005) were, $66.1 \%$ (90.0\%) of print materials, $9.6 \%$ (4.6\%) of audio, $4.4 \%$ (5.8\%) of video, and $18.4 \%$ (1.0\%) of e-books. (The Institute of Museum and Libraries Services, 2016) 


\subsubsection{Previous Studies on Public Library}

Public libraries $^{2}$ are understudied in the economics field. This is not an economics issue alone. For instance, Knight and Nourse (1969) commission's report asked for further studies on public libraries instead of providing recommendations per se. Even though there are numerous journals specialized on libraries, this topic seems to be scarce among other disciplines. The first study on public libraries by economists is attributed to Tiebout and Willis (1965) discussing the public nature of public libraries. The authors argue that public libraries are a public good that generates positive externalities, and thus have an underestimated demand. This implies an under support to public libraries.

The discussion of public libraries in economics was followed by studies applying an economics perspective to the library industry. The idea was simple, libraries are firms providing services to individuals and communities. However, in light of local public finance, the provision of its services should be efficient. Thus, the focus laid on estimation of demand, unit-costs analysis, technical efficiency and cost-benefit analysis (Pfister and Milliman, 1970; Goddard, 1970; Feldstein, 1976; Stratton, 1976; Getz, 1980). It is interesting that the same arguments in favor and against studies focusing on public libraries are similar to current ones, such as: budget pressures, technology advancement, demand for its services, among others.

This trend continued in the field and most studies that followed had a similar focus. Jackson (1974) applied an erosion analysis to public libraries, showing that an increase in population can lead to a decrease in output from the resources used in the production of services. Bookstein (1981), in turn, provided a microeconomic model of public library activity, and argued that due to the intangibility of the service provided, public libraries could be underfunded. DeBoer (1992) estimated a cost function to Indiana public libraries, finding evidence of economies of scale up to a certain threshold of output which is measured by circulation. Hammond (1999) also estimated a cost function, but the author considered a multi product output in the UK library systems and found evidence of increasing returns

\footnotetext{
${ }^{2}$ Baumol and Matityahu (1973) make a thorough analysis of academic libraries in the US, and Reichmann and Sommersguter-Reichmann $(2006,2010)$ investigate the efficiency of academic libraries in several countries like Australia, Austria, Canada, Germany, Switzerland and the United States.
} 
to scale as well, but diseconomies of scope.

Several papers analyze the technical efficiency of public libraries using different approaches such as Data Envelopment Analysis and Stochastic Frontier, focusing on different countries such as Australia (Worthington, 1999), Belgium (Witte and Geys, 2011), United Kindgom (Hammond, 2002, 2009), and the United States (Hemmeter, 2006). In the US, in particular, Sharma et al. (1999) focus on Hawaii, Vitaliano (1997) and Vitaliano (1998) on New York State, and Ferreira Neto and Hall (2018) on West Virginia. In terms of demand for public libraries: Young (1973) analyzed the determinants of public library demand in the UK and Wales; Aabø (2005) applied a contingent valuation to determine the willingness to pay for library services in Norway; and Locher (2005) focused on the effects of library fees in Germany.

On the other hand, there are no studies that analyze the impact of library on different outcomes. The closest is Bhatt (2010). Using an instrumental variable approach, she found that an increase in library use increases time spent reading, decreases time spent watching TV and for children at schools, it increases homework completion rates. Fujiwara et al. (2017) used a survey of users and non-users of public libraries in the UK showing a positive association between public library use and self-reported happiness and health status. Conversely, Ferreira Neto (2018) studied the impact of government funding on private donations to public libraries in the US, and find suggestive results of a crowd-in effect.

Stine (2008) looked at how volunteer workers impact the demand of labor from public libraries. He found a complementary relationship between volunteer work and library staff. Further, although not focused on library use per se, Betts (1995) and Farber and Gibbons (1996) use information on library card holding to proxy for unobservable ability in a Mincerian wage regression.

\subsection{Contributions and Outline}

This dissertation includes three chapters on the economics of public libraries. Differently from previous dissertations that focused on the public library industry by examining its demand, cost structure, efficiency, among other features as previous dissertations (Pfister and 
Milliman, 1970; Goddard, 1970; Feldstein, 1976; Stratton, 1976; Getz, 1980), this dissertation has an applied perspective, analyzing direct and indirect effects to and from public libraries, on different issues such as charitable donations, labor market outcomes, institutions and technical efficiency.

In light of the pressure to reduce public budgets, Chapter 2, focuses on sources of revenue to public libraries since over $90 \%$ of public libraries revenue comes from government sources, either local, state or federal. In particular, Chapter 2 aims at evaluating the donations to public libraries at an institutional level and testing the hypothesis of donations being crowd out by government expenditure. If government funding crowds out private donations in the case of public libraries, decreasing revenues from government sources may induce an increase in private donations; however, if government funding brings in more private donation (crowding in effect), then budget cuts can have unforeseen consequences to public libraries.

To address this question, I use the Public Library Survey, which can be considered the census of public libraries, and focus on the period between 2000 to 2013 given the role of internet after the 2000s. The main results show a positive correlation between government funding and private donation to public libraries, suggesting a crowd in effect. The estimated effects are between 4 cents and 1.3 dollars, depending on the level of government.

Chapter 3 explores the idea that public libraries are not only about books but also about several other programs and services. Thus, Chapter 3 investigates the impact of public library programs for children and adults and their participation on local labor markets outcomes in the Appalachian region. In particular, I focus on unemployment and labor force participation.

One important concern is that these programs and their attendance can be endogenous to local labor markets. That is, public library programs can be pro- or counter-cyclical to business cycles, therefore cyclical to local labor markets outcomes as well. Hence, I make use of an instrumental variable (IV) approach to provide causal inference. I use the number of librarians without master's degree and the amount of print material and computers for public use as instruments for the number of programs and the participation in these programs.

The results show adult and children's program and participation do not affect local labor market outcomes. These results are robust across several specifications. However, 
when accounting for spatial dependence and possible spillovers, I find suggestive results of indirect effect of library programs and participation. More specifically, I find that neighboring children's programs and participation have a positive effect on local labor market outcomes, i.e., decrease unemployment and increase labor force participation. Conversely, neighboring adult participation has a negative impact on local labor market outcomes.

Chapter 4, jointly with Josh Hall, explores the institutional determinants of public library technical efficiency using data from West Virginia. First, we evaluate the efficiency of West Virginia public library systems. Then, using our measures of technical efficiency, we test whether the source of funding matters for efficiency. Last, we explore how county characteristics affect the technical efficiency.

We estimate the technical efficiency of public libraries in West Virginia using Data Envelopment Analysis (DEA) and find that the average public library system in our sample is between $81 \%$ and $90 \%$ efficient. The econometric results, on the other hand, show that local, that is, non- county or multi-jurisdictional, libraries have lower levels of technical efficiency. This suggests an inability to take advantage of economies-of-scale. In addition, contrary to what the work of Hoxby (1999) and Hall (2007), we find a negative relationship between local support and technical efficiency. As for demographic characteristics, we can highlight that counties with lower high-school graduation rates, less multi-racial population, and higher population between 45-64 years are associated with more technically efficient public library systems.

The contributions of this dissertation are threefold. First, this is to the best of my knowledge the first systemic body of work on public libraries since the 1970s. Public libraries are part of the American culture and valued by patrons (Wiegand, 2015; Bertot et al., 2012), however, they have not gained much attention from economists. Second, results in chapter 2 and 3 provide evidence that reducing funding and programs from public libraries can have undesired consequences. The former chapter provides evidence of crowding in effects from government funding while the latter shows spillover effects from children's programs and participation. Lastly, the institutional setting for each public library system can vary due to historical, management, or location reasons for example (Wiegand, 2015; Katz, 2006). Chapter 4 , shows how these settings may impact the provision of services from public libraries. 


\section{Chapter 2}

\section{Charity and Public Libraries: Does Government Funding Crowd Out Donations?}

\section{$2.1 \quad$ Introduction}

Recent pressure to reduce public budgets have been affecting public libraries all across the country. There are, for example, reports of budget cuts in libraries in New York, Florida, Nebraska, Georgia, Michigan and Oregon ${ }^{1}$ (Blau, 2011; Warburton, 2013). These budget cuts may have a significant negative effect on public libraries, as over 90 percent of their revenues, which accounted for $\$ 11.5$ billion dollars in 2012 , comes from governments (IMLS, 2014a). Thus, such government budget cuts make other components of a library's revenue, namely, donations from private individuals and grants, relatively more important.

In the United States there are 9,082 public libraries, which correspond to approximately 8 percent of all libraries in the country (ALA 2015). The Institute of Museums and Library Services (IMLS, 2014a) reported that these public libraries accounted for 1.5 billion in-person visits in 2012. By looking at the libraries' revenue and in-person visits numbers alone, it is possible to understand the importance of public libraries in a public finance perspective.

\footnotetext{
${ }^{1}$ Smith (2015); Kelley (2015); Davis (2015); Stepleton (2015); Woods (2015); Cleaver (2015) also present reports on library budget cuts. A quick search on Google News can present the interested reader with other recent examples.
} 
However, public libraries also provide important services that can be overlooked sometimes, such as Internet access and job searching, for example (ALA 2015 and Bertot et al. 2012). Moreover, Bhatt (2010) shows that visiting a library increases the time children enrolled in school spend at home reading. In turn, this positively impacts their homework completion rates.

Therefore, given the importance of public libraries as a service versus the losses on revenue due to pressure on budget cuts, this chapter focuses on sources of revenue to public libraries. More specifically, this chapter aims to evaluate the donations to public libraries at an institutional level, and test the hypothesis of donations being crowded-out by government expenditure. Hence, I contribute to the growing empirical literature on charitable donations, focusing specifically on public libraries, which are different than private non-profits or charitable organizations. Note that there are public libraries that can be considered non-profit organizations as well. ${ }^{2}$ A key difference from private non-profits and public non-profits is that the former can receive government funding via government grants only, while public non-profits are entitled to tax-payer money as well. Therefore, one can expect the behavior from donors to differ between private and public as there can be differences in management given the funding sources (Hardina, 1990; Hodge and Piccolo, 2005). In addition, there is a gap in the empirical literature of donations and cultural goods with papers discussing museums (Maddison, 2004; Yermack, 2017), the National Endowment of Arts (Borgonovi and O'Hare, 2004) and Theaters (Borgonovi, 2006). Moreover, few studies consider the role played by different locations (i.e., the historic aspects), except for the differences in tax exemption.

With regard to historical aspects, charity in the United States, especially during Colonial times, was influenced by England. As an example, Americans followed ideas of entrusting some charity responsibilities to local authorities and private agents (Katz, 2006). After the Revolutionary War, however, the environment for charity support was hostile all across the country, except for New England. After several actions from the Supreme Court in the

\footnotetext{
${ }^{2}$ As per the Public Library Survey Documentation, a non-profit public library is "An entity privately controlled but meeting the statutory definition of a public library in a given state." However, as shown in table 2.1 that only a small part of public libraries meet this criterion.
} 
19th century, charitable activity thrived in the Northeast and upper Midwest. However, these activities did not perform as well in other regions of the country (Katz, 2006). Although demographic changes have occurred since then, most of the institutional framework remains similar as do regional traditions and characteristics. This suggests that regional characteristics may still play a role in donation behavior.

Katz (2006) provides a brief discussion about the American interest in giving. The author concludes that "their instinct to imagine and support the non-profit engines of human betterment derive from the original Carnegie-Rockefeller tradition" (Katz 2006, 1316); in other words, an altruistic behavior. Andreoni (1990) states that people are not indifferent between who makes a donation: themselves or others. Thus, when taking altruism into account, the public goods model provides more intuitive results. Examples of such results are that the distribution of income matters when it comes to donations, governments do not crowd out private provision, and subsidies can have the desired effect on donations (Andreoni, 1990).

There are several studies that analyze how different institutions or features impact charity giving. Gruber and Hungerman (2007) and Khanna et al. (1995), for instance, focus on religion; Beranek et al. (2010), Bakija et al. (2003) and Peloza and Steel (2005) concentrate on tax systems; Borgonovi (2006), Steinberg (1991), Brooks (2003), Simmons and Emanuele (2004), Okten and Weisbrod (2000) and Payne (1998) study the impact of government funding on private donation.

This chapter's interest resides primarily in examining the role of government on private donation behavior. Some of the results found in the literature ${ }^{3}$ are as follows: Simmons and Emanuele (2004) find a negative relation between government spending and donations. Payne's (1998) study of shelters between 1982 and 1992 finds evidence of crowding out when controlling for possible endogeneity of government grants. Okten and Weisbrod (2000) analyze Internal Revenue Service data for individual non-profits between 1982 and 1994 and find that: (i) the price of donation has a negative effect on donations, (ii) the government's

\footnotetext{
${ }^{3}$ Borgonovi (2006) provides an extensive review of the literature on government effects on donations: crowd out and crowd in. Steinberg (1991) also provides an extensive review of the crowd out literature and raises important questions and issues to improve estimations.
} 
grant and own programs do not crowd-out private donations, and (iii) surprisingly, there is a positive effect of government grants and own program sales in donations in most of the industries analyzed. Brooks (2003) finds a neutral effect of public funding on total donation. Borgonovi (2006) finds evidence of crowd-out effects of government funding on private donation to theaters.

To address the question of how government funding affects donations to public libraries, I use the Public Library Survey. This survey can be considered the census of public libraries because it has a rate of response of over 98 percent. I restrict my sample to the years of 2000 to 2013 and evaluate the donations to individual public libraries. To test the hypothesis that government crowds-out donation, I regress the amount of revenue from the different levels of governments on the revenue from donation. I differentiate the levels of government because Borgonovi (2006) argues that the level of donations and support are relevant. Also, I follow Brooks (2003) and Borgonovi (2006) and specify a quadratic relation for the government revenues. Moreover, I control donations for library features and demographics at a state level. Finally, the panel structure of the data allows me to control for fixed effects at a county and state level. The main results show a positive correlation between donations and government expenditure, hinting at a crowding-in effect. The estimated upper bound is between 4 cents to 1.3 dollars, depending on the level of government. Furthermore, regional differences seem to be important but not determinant when it comes to charitable giving.

The remainder of the chapter is structured as follows: Section 2 describes the intuitive model and the empirical approach to estimate the crowding effect; Section 3 presents the Public Library Survey data and its descriptive statistics; Section 4 discusses the results; and Section 5 concludes, laying out some implications of study.

\subsection{Methodological Approach}

Bekkers and Wiepking (2011) provide a literature review of over 500 studies on charitable giving and argue there are eight mechanisms that drive this behavior: awareness of need, solicitation, costs and benefits, altruism, reputation, psychological benefits, values and efficacy. The authors argue that the awareness of need is a prerequisite to charitable donations, since 
donors need to know that an entity needs their support. Solicitation would also represent a prerequisite, while the other drivers are characteristics or perceptions from the donors. This chapter does not intend to review these mechanisms, but with those in mind and following the work of Parret (2006) on tipping it is possible to derive a conceptual model for donation.

Consider a donor i that maximizes his/her utility $(U)$ by choosing how much to donate $(D)$.

$$
\max _{D_{i}} U_{i}=-D_{i}+\gamma_{i}\left(D_{i}+\phi(g, b)+\psi(c, b)\right)
$$

The utility function above represents the trade-off between donating and the benefits acquired from donating. The first term, $-D_{i}$, is the monetary disutility in donating. The second term, $\gamma_{i}\left(D_{i}+\phi(g, b)+\psi(c, b)\right)$, is the utility received from the donation. The function $\phi$ represents the perceived awareness of need, and depends on the government revenue to libraries $(g)$ and the donors' perceptions $(b)$. The function $\psi$, on the other hand, represents the characteristics $(c)$ and perceptions $(b)$ of the donor, as described by Bekkers and Wiepking (2011). Because the interest of this chapter resides on the relation between $D$ and $g$, I abstract away from the other parameters.

Assuming that the utility function is strictly concave in donation, and that function $\gamma$ is increasing and concave in $\left(D_{i}+\phi(g, b)+\psi(c, b)\right)$, we can obtain the first order condition to the problem in equation 2.1. Superscript refers to the partial derivative.

$$
\frac{\partial U_{i}}{\partial D_{i}}=-1+\gamma^{D}\left(D_{i}+\phi(g, b)+\psi(c, b)\right)
$$

Using the implicit function theorem, it is possible to obtain the comparative statics and the relation between government spending and donation:

$$
\frac{\partial D_{i}}{\partial g}=-\frac{\gamma_{D g}\left(D_{i}+\phi(g, b)+\psi(c, b)\right) *\left[\frac{\partial \phi}{\partial g}\right]}{\gamma_{D D}\left(D_{i}+\phi(g, b)+\psi(c, b)\right)} \gtrless 0
$$

Due to the strictly concavity of the utility in donation, it is possible to determine that the denominator is negative. The first term in the numerator, $\gamma_{i}^{D g}\left(D_{i}+\phi(g, b)+\psi(c, b)\right)$, is the effect of the government revenue to libraries in the marginal benefit from donation. This effect can be either positive, if the donation and government funding are seen as complements, 
or negative if they are seen as substitutes The term $\frac{\partial \phi}{\partial g}$ has also no pre-determined sign. On the one hand, government spending can indicate that a particular library has been taken care of, and therefore the perceived awareness of need is smaller for every dollar amount of government revenue, implying a crowd-out effect. On the other hand, the government spending can be an indicative of need or worth of the library and work as a signaling mechanism as argued by Borgonovi (2006). In this case, every dollar spent would increase the perceived awareness of need, suggesting thus a crowding-in effect. Thus, the indetermination on the signing of Equation 2.3 comes from the numerator.

Hence, following a similar framework used by Borgonovi (2006), I evaluate the crowding effect from government spending at an institutional level estimate the equation:

$$
\begin{gathered}
\text { Donation }_{n c s t}=\alpha+\beta_{1} L O C G V T_{n c s t}+\beta_{2} S T G V T_{n c s t}+\beta_{3} F E D G V T_{n c s t} \\
X_{n c s t} \gamma+Z_{s t} \delta+\mu_{n}+\eta_{c}+v_{s}+\lambda_{t}+\varepsilon_{n c s t}
\end{gathered}
$$

where, Donation ${ }_{n c s t}$ is the amount donated to library $n$, in county $c$, in state $s$, in year $t$; LOCGVT is the amount of revenues from local government; STGVT is the amount of revenues from state government; FEDGVT is the amount of revenues from federal government; $X_{n c s t}$ are the characteristics of the library $n ; Z_{s t}$ are the demographic characteristics of the state; $\mu_{n}, \eta_{c}$, and $v_{s}$ are non-observable characteristics of the library, county, and state, respectively; $\lambda_{t}$ is the time fixed effect; and $\varepsilon_{n c s t}$ is the error term.

Unfortunately, I cannot observe donations per se. I can, however, observe other types of revenues, namely, fees, grants and donations. It is expected that the largest share of these "other revenues" are donations, as fees and fines would represent a smaller value. This intuition can be checked by comparing the information provided by Dixon and Gillis (2017) and Rosa (2014) with the information from IMLS (2014a). According to the latter, the "other revenues" represent $8.2 \%$ share of the 11.5 billion dollars in revenues, which represents a total of 943 million dollars approximately. Dixon and Gillis (2017) estimate public libraries collect 6.5 million dollars in revenue per month, which sums to 78 million dollars yearly. Rosa (2014), on the other hand, points to an approximately 200 million dollars in grant revenues to public libraries. Therefore, grants and fees would sum to 278 million dollars which represents $29.5 \%$ of the "other revenues". 
Borgonovi (2006) argues that the interdependent utility model is the base for the charitable donation literature (Reece, 1979; Abrams and Schmitz, 1984; Andreoni and Scholz, 1998; James, 2008), and that it is important to differentiate between the levels of government when analyzing crowding effect. She explains that this model can either capture a crowd-in or crowd-out effect, which is similar to the conceptual model presented above. Brooks (2003), in turn, suggest a quadratic form in an inverted U shape. As pointed by de Wit and Bekkers (2017) both results of crowding in and out effects exist are common in the literature. Hence, there is no expectation toward the signs of $\beta_{1}, \beta_{2}$, and $\beta_{3}$.

As discussed in the previous sections, the regional characteristics may influence the level of donation. The vector $Z_{s t}$ controls for observable variables such as average age and the percentages of women, white and black people, married couples, immigrants, people with high school degrees and bachelor degrees, unemployed people. The $\eta_{c}$ and $v_{s}$ terms capture non-observable characteristics, including tax. Also, I created three other dummy variables assuming value of one if the library is either in the New England, Mideast or Great Lakes regions in order to control for the regions highlighted by Katz (2006).

The author points out that different regions in the United States followed different traditions with respect to charitable donations. These activities thrived in the Northeast and upper Midwest, but not in the South. Moreover, tax $(\tau)$ systems in each state differ from each other, what make incentives different for private donors, because taxes would represent the price of giving (Feldstein and Taylor, 1976; Clotfelter, 1980; Andreoni, 1989; Brown and Lankford, 1992).

The variables in the $X_{n c s t}$ vector are: attendance, kids' programs attendance, book collection, number of employees, number of hours opened, number of computers with access to the Internet for the general public and a dummy variable if the library had any contemporaneous capital outlay.

\subsection{Data}

The Public Libraries Survey (PLS) has been collected annually since 1988 and covers all 50 states, the District of Columbia, and outlying territories. It provides statistics for almost 
every public library in the United States (IMLS 2014a). As the PLS has over a 98 percent response rate, it can be considered a census of public libraries in the United States.

According to the IMLS website, these data are not attached to any specific program, and it is not mandatory. Therefore, there are no incentives to over- or under-report the values in the survey, which makes this data less subject to biased reporting. The PLS survey provides data for each library system covering several features, such as: location (full address and geocodes), state characteristics (population serviced), and administrative data (number of staff, revenues by source, costs, collection expenditures, collection, circulation, attendance, among others).

Baumol and Matityahu (1973) make a thorough analysis of academic libraries and argue that the changes in technological structure in libraries due to the use of computers would shape the costs and use of libraries in the long run. With the advance of internet, especially since the 2000s, there has been a shift in the function of libraries and their perception from the general public; fewer physical books are required and the collaboration between libraries has increased. Therefore, I restrict my analysis to the years of 2000 to 2013 to reflect these changes.

The data ${ }^{4}$ on the characteristics of the states comes from a sample of the Integrated Public Use Microdata Series - Current Population Survey (IPUMS-CPS - Flood et al. 2015) provided by the Minnesota Population Center. The sample is at an individual level, and it was aggregated to state level averages using weights provided by the IPUMS-CPS. Table 2.1 presents the descriptive statistics of both datasets used in this chapter.

I use the IPUMS-CPS variable for deflation and I drop from my sample the 30 observations considered outliers 5 ; i.e., libraries with more than $\$ 1.4$ million dollars in real terms. It is noteworthy that from the 30 dropped observations, 14 of them are the New York Public Library. Figure 2.1 shows donation versus each level of government expenditure with (above) and without (below) outliers.

\footnotetext{
${ }^{4}$ The "Appendix" chapter has a description of each variable used in the chapter and their source.

${ }^{5}$ The outlier libraries are: Los Angeles Public Library (CA0063) in 2004 and 2005; Enoch Pratt Free Library (MD0003) from 2006 to 2009; Las Vegas-Clark County Library District (NV0008) in 2000 and from 2003 to 2010; New York Public Library from 2000 to 2013; and Columbus Metropolitan Library (OH0057) in 2012 .
} 
Another important feature of the data is the difference in the schedule of the reports ${ }^{6}$. To control for this, I included a dummy variable in the OLS regression, however, because of collinearity, this dummy is dropped on the state fixed-effects model, which would also capture this difference.

\subsection{Results}

The results are presented from Tables 2 to 4 , with only the variables of interest included. Table 2.2 presents the main results. Column (1) has the Pooled OLS model and column (2) the fixed effect - year, county, state and library - one. The left-truncated characteristic of the data makes the results presented in columns (1) and (2) biased and not consistent. Therefore, in columns (3) and (4) I present the results with Tobit estimations.

Following Borgonovi (2006), the data structure of the Public Library Survey allows me to differentiate the government expenditure on its several levels - local, state and federal. The author shows that for theaters this distinction is significant, and from Table 2.2 the same holds for public libraries. In all the models regressed, there is a positive correlation between donations and government spending, suggesting a crowding-in effect of government expenditure on every level.

By focusing on the results presented in column (4), i.e., the fixed effect Tobit estimation, every dollar spent by local, state and federal governments is correlated with an increase by 1.1 cents, 18 cents and 1 dollar and 6 cents in donations, respectively. Because this model does not capture the regional effects, we turn the attention to column (3) which indicates a positive correlation between the selected regions and donations. Also, the results in fixed effect models, imply that regional unobservable effects affect donations to libraries. However, I do not have a clear picture if the historical features described by Katz (2006) are still in place. Moreover, the results hint at an inverted U shape curve feature at every level of government expenditure, similar to the results in Brooks (2003).

\footnotetext{
${ }^{6}$ States reporting for calendar year: AK, AZ, CA, CT, DE, GA, HI, IA, AK, AZ, CA, CT, DE, GA, HI, IA, NM, NV, OK, OR, RI, SC, TN, VA, WV, WY; for fiscal year: AR, CO, IN, KS, LA, ME, MN, ND, NJ, OH, TX, SD, WA, WI, PW; and other schedule: MI, PA, VT, NY, NH, UT, AL, DC, FL, ID, MS, NE, GU, MP, VI.
} 
Because I include a dummy if the library is run by the school district and a dummy if the library is run by a non-profit the number of observations in the first two columns of Table 2.2 is smaller than the other regressions. Fischel (2007) argues that there should be congruence between city and school district boundaries, resulting in synchronization between public library programs and school curricula. Also, if parents were to donate to a public library, having the library run by the school district would be one argument in favor of donations. However, the results show no statistical significance for this dummy variable. On the other hand, being run by a non-profit has a positive statistically significant result in the OLS model and county-year fixed effect model, but a negative sign in the library-countystate-year fixed effect model. Hence, when taking non-observable characteristics of libraries into account, the results suggests not-for-profit libraries receive fewer donations.

The crowding-in effect when analyzing a cultural sector is not new in the literature. For example, Paqué (1982) finds evidence of crowding-in effect in art activities in Germany; Okten and Weisbrod (2000) find crowding-in effect in libraries, research and higher education; Smith (2003) finds crowding-in for dance companies; and Borgonovi (2006) finds crowding-in effect on expenditure of local government in theaters.

Borgonovi (2006) argues that the crowding-in effect can be explained by a signaling mechanism. Donors would consider libraries that receive government funding as ones with a better reputation, thus more secure in which to invest. Another argument provided by the author is the independent utility framework, "the additional support that public grants provide at low levels of total donative revenues (public and private) allows recipients to expand their activities and undertake new and/or better projects" (Borgonovi 2006, 432). It is important to stress again that one of the caveats of this chapter is not being able to disentangle donations from grants and fees. 


\subsubsection{Robustness Check}

In this subsection ${ }^{7}$ I present some other models estimated as robustness checks ${ }^{8}$. First, I present models with per capita values, using the legal service area as a catchment area. This is an important exercise because not considering a catchment area can lead to overestimated results. Then, I present the results for all the data; that is, I include the 30 outliers removed earlier as a sensitivity analysis.

Although I controlled for population in the previous estimated equations, this does not capture the catchment area of each library. Table 2.3 presents the results for the estimated per capita models, following the structure of Table 2.2. The results have the same features as those in Table 2.2: there is a positive correlation between donation and all levels of government and an inverted $U$ shape for local and federal government. It is interesting to note that the coefficients have a slight decrease such that the local government would bring around 2 cents, state government 3 cents and federal government 1 dollar and 25 cents. The regional dummies, although statistically significant, are close to zero. The Tobit results suggest local governments crowd in 4 cents for every additional dollar spent, local governments brings in 20 cents, and federal governments increase donations by 73 cents.

Lastly, it is important to make a sensitivity analysis and estimate the models including the outliers removed from previous analysis. Table 2.4 presents the POLS, Fixed Effects and Tobit results using the complete dataset. Focusing on the Tobit model with fixed effects, the results suggest that there is a crowd-out effect from local government of 5 cents and a crowd-in effect from state government (42 cents) and federal government (3 dollars and 30 cents). The

\footnotetext{
${ }^{7}$ One important discussion in the crowd out literature is the ability to identify a causal relation between donation and government expenditure. This is not truly possible with the dataset I use. Nevertheless, on the appendix chapter, I present another robustness test using instrumental variables. Overall, the results show a crowd in effect and an inverted U shape in all levels of government. It is important to stress again that even with the use of instrumental variables, I cannot claim I have a causal effect because I cannot disentangle donation from grants and fees.

${ }^{8}$ Besides the robustness checks presented on the text I also run two extra tests. To try to account for specific county or state time trends I estimated a model with both the interactions between year and county and year and state fixed effects. For this regression analysis, the local government has positive sign, but is not statistically significant. The state government revenue result implied a crowd out relation to donation of 18 cents, while the federal government results suggested a crowd in effect of 16 cents. These results are only for OLS estimation with fixed effects. Using lag government revenues other than contemporaneous spending shows a positive correlation for government spending and donations for local (2 cents) and federal (30 cents) governments and a negative correlation for state (10 cents) government. These are available upon request.
} 
inverted $\mathrm{U}$ shape is only found for the state and federal government expenditures. Although these results only corroborate the results for state and federal government, the outliers are most concerning in the relationship between local government and donation as seen in Figure 2.1. Therefore, I believe the results presented in Table 2.2 are more accurate than those in Table 2.4 .

\subsection{Conclusion and Implications}

The goal of this chapter is to evaluate the crowding effect of government expenditure on private donations to public libraries. By doing so I contribute to the literature in two ways. On one hand, I use a panel of public libraries from 2000 to 2013 from the Public Library Survey to determine if government crowds-out donations. This dataset, which is overlooked in the economics literature, allowed me to identify revenues from donation and from the different levels of government - local, state and federal - and several features of each library. Also, I used data from the IPUMS-CPS, provided by the Minnesota Population Center, to control for state socio-demographic characteristics.

The second contribution stems from the object of research itself, i.e. public libraries. Most public libraries are not considered private non-profit organizations - according to Table 1 in page 22 only $16 \%$ of my sample is considered not for profit institutions. Thus, instead of looking at private charitable organizations, I focus on a government provided service which is struggling due to decreasing revenues from government and is relying on external revenue sources $^{9}$.

The results show a positive correlation between donation and government spending in every level, which points to a possible crowding-in effect. That is, every dollar spent by the government would bring some extra amount of money to the libraries. More specifically, the results suggest local government would bring an extra 4 to 6 cents in donation, state government 20 to 23 cents and the federal government 73 cents to 1 dollar and 33 cents per dollar spent. As do Borgonovi (2006) and Brooks (2003), I also find an inverted U shape

\footnotetext{
${ }^{9}$ For instance, the American Library Association has on its Web site a toolkit to help librarians run successful fundraisers (http://www.ala.org/advocacy/advleg/frontlinefundraising).
} 
relation between government expenditure and donation.

The results in the regional difference due to historic features described by Katz (2006) were not statistically significant or close to zero, hinting that these regions are not different from other U.S. regions. This provides some evidence that there has been some homogenization in terms of donation, at least to public libraries.

There are several implications from the results presented above. First, the results are another empirical contribution to the crowding effect of government expenditure. As well as other cultural types of activities, such as those analyzed in Paqué (1982), Okten and Weisbrod (2000), Smith (2003), and Borgonovi (2006), government revenues are correlated with more donation. In this particular case, the results imply government crowd in donation in every level - local, state and federal. This would also corroborate the interpretation from Borgonovi (2006) in which donors use government funding as a signaling mechanism.

Secondly, as a result of the crowd-in effect, the cuts on government budgets to public libraries would mean they are worse than anticipated by policy-makers. For once, there is no guarantee that any level of government would compensate the loss in revenues from another level of government. Moreover, the results indicate that libraries whose revenues are cut would also lose money from donation as well, because donors would have a different perception due to the signaling mechanism.

Lastly, it is important to describe some consequences of these results for public policies. According to IMLS (2014a), 91.8 percent of library revenues come from government; 84.4 percent are local, 6.9 percent are state and 0.5 percent is federal. This breakdown helps to shed light on the reason why every dollar from state and federal governments would bring more dollars from donation. However, it is clear that the biggest providers are local governments. Even with the extra amount of dollars that state and federal levels can bring, this extra amount would not suffice to cover cuts from local governments, at least not in an aggregate level.

Therefore, policy-makers should be cautious when cutting funds from public entities, especially from cultural-type entities such as public libraries because: (i) there seems to be an indirect budget effect that could further decrease revenues due to the suggested crowdin effect; (ii) there might not be a substitution allowed in donation, i.e., donors could not 
reallocate a donation to a library into another public provided service, which could place more pressure on local governments; (iii) the direct cuts may force public libraries to close, which can have negative externalities, for instance, less access to the Internet and to jobs (ALA 2010 and Bertot et al. 2012), a negative impact on education (Bhatt, 2010), and less tax-revenue if people value living close to libraries Sheppard et al. (2006), among others.

Some of the caveats of this chapter are the donation measure and level of observation. For the former, I cannot disentangle donation from grants and fees; therefore, I cannot conclude there is a casual effect between donation and government funding. At most, the results show they have a positive correlation between them. The ideal dataset would enable me to observe the characteristics of donors and the institutions to which they donate. Hence, I would be able to have better measurements to test the warm-glow hypothesis and to understand the relationship between donation and government expenditure. However, I must highlight that this does not invalidate this work, which still provides interesting results using novel data to analyze the determinants of donation. 
Table 2.1: Descriptive Statistics

\begin{tabular}{|c|c|c|c|c|c|}
\hline Variable & $\mathrm{N}$ & Mean & Std Dev & Min & Max \\
\hline Donation & 128,759 & 0.08 & 0.86 & 0 & 86 \\
\hline Local & 128,759 & 0.77 & 3.32 & 0 & 130 \\
\hline State & 128,759 & 0.09 & 0.77 & 0 & 54 \\
\hline Federal & 128,759 & 0.01 & 0.05 & 0 & 4 \\
\hline Population & 128,759 & 0.03 & 0.13 & 0 & 4 \\
\hline Master & 128,759 & 3.40 & 14.87 & 0 & 754 \\
\hline Librarian & 128,759 & 5.01 & 16.50 & 0 & 754 \\
\hline OtherPaid & 128,759 & 10.02 & 40.83 & 0 & 2,211 \\
\hline HrsOpen & 128,759 & 3972.23 & 8433.19 & 0 & 250,380 \\
\hline Visits & 128,759 & 0.15 & 0.58 & 0 & 18 \\
\hline KidAttendance & 128,759 & 6290.64 & 20845.86 & 0 & 682,048 \\
\hline Computers & 128,759 & 21.68 & 76.81 & 0 & 4,123 \\
\hline BookVolume & 128,759 & 86.64 & 358.26 & 0 & 22,016 \\
\hline AudioCol & 128,759 & 4666.87 & 26245.21 & 0 & $2,358,459$ \\
\hline VideoCol & 128,759 & 4654.83 & 17744.49 & 0 & 796,018 \\
\hline Age & 128,759 & 36.80 & 1.57 & 30 & 41 \\
\hline Pincome & 128,759 & 17.43 & 2.68 & 11 & 27 \\
\hline Female & 128,759 & 0.51 & 0.01 & 0.48 & 0.54 \\
\hline White & 128,759 & 0.84 & 0.08 & 0.18 & 0.99 \\
\hline Black & 128,759 & 0.10 & 0.07 & 0 & 0.65 \\
\hline Married & 128,759 & 0.42 & 0.02 & 0.22 & 0.49 \\
\hline Immigrant & 128,759 & 0.05 & 0.04 & 0 & 0.17 \\
\hline HighSchool & 128,759 & 0.25 & 0.03 & 0.15 & 0.36 \\
\hline College & 128,759 & 0.13 & 0.02 & 0.06 & 0.23 \\
\hline Unemploy & 128,759 & 0.03 & 0.01 & 0.01 & 0.08 \\
\hline SchDistrict & 114,015 & 0.01 & 0.09 & 0 & 1 \\
\hline NonProfit & 114,015 & 0.16 & 0.37 & 0 & 1 \\
\hline Kap & 128,759 & 0.45 & 0.50 & 0 & 1 \\
\hline
\end{tabular}


Table 2.2: Results

\begin{tabular}{|c|c|c|c|c|}
\hline & \multicolumn{4}{|c|}{ Dependent variable: Donation } \\
\hline & \multicolumn{2}{|c|}{ OLS } & \multicolumn{2}{|c|}{ Tobit } \\
\hline & (1) POLS & (2) $\mathrm{FE}$ & (3) Pooled & (4) $\mathrm{FE}$ \\
\hline Local & $\begin{array}{c}0.028^{* * *} \\
(0.001)\end{array}$ & $\begin{array}{c}0.002 \\
(0.002)\end{array}$ & $\begin{array}{c}0.020^{* * *} \\
(0.001)\end{array}$ & $\begin{array}{c}0.011^{* * *} \\
(0.001)\end{array}$ \\
\hline Local2 & $\begin{array}{c}-0.000^{* * *} \\
(0.000)\end{array}$ & $\begin{array}{c}-0.000^{* * *} \\
(0.000)\end{array}$ & $\begin{array}{c}-0.000^{* * *} \\
(0.000)\end{array}$ & $\begin{array}{c}-0.000^{* * *} \\
(0.000)\end{array}$ \\
\hline State & $\begin{array}{c}0.188^{* * *} \\
(0.002)\end{array}$ & $\begin{array}{c}-0.066^{* * *} \\
(0.004)\end{array}$ & $\begin{array}{c}0.159^{* * *} \\
(0.002)\end{array}$ & $\begin{array}{c}0.180^{* * *} \\
(0.002)\end{array}$ \\
\hline State2 & $\begin{array}{c}-0.003^{* * *} \\
(0.000)\end{array}$ & $\begin{array}{c}-0.001^{* * *} \\
(0.000)\end{array}$ & $\begin{array}{c}-0.003^{* * *} \\
(0.000)\end{array}$ & $\begin{array}{c}-0.003^{* * *} \\
(0.0001)\end{array}$ \\
\hline Federal & $\begin{array}{c}0.597^{* * *} \\
(0.027)\end{array}$ & $\begin{array}{c}0.237^{* * *} \\
(0.022)\end{array}$ & $\begin{array}{c}0.762^{* * *} \\
(0.027)\end{array}$ & $\begin{array}{c}1.060^{* * *} \\
(0.027)\end{array}$ \\
\hline Federal2 & $\begin{array}{c}-0.188^{* * *} \\
(0.011)\end{array}$ & $\begin{array}{c}-0.089^{* * *} \\
(0.008)\end{array}$ & $\begin{array}{c}-0.205^{* * *} \\
(0.011)\end{array}$ & $\begin{array}{c}-0.290^{* * *} \\
(0.011)\end{array}$ \\
\hline NewEngland & $\begin{array}{c}0.014^{* * *} \\
(0.003)\end{array}$ & & & \\
\hline Mideast & $\begin{array}{c}0.044^{* * *} \\
(0.003)\end{array}$ & & & \\
\hline GreatLakes & $\begin{array}{c}0.007^{* * *} \\
(0.002)\end{array}$ & & & \\
\hline logSigma & & & $\begin{array}{c}-1.551^{* * *} \\
(0.002)\end{array}$ & $\begin{array}{c}-1.574^{* * *} \\
(0.002)\end{array}$ \\
\hline Library Control & $\sqrt{ }$ & $\sqrt{ }$ & $\sqrt{ }$ & $\sqrt{ }$ \\
\hline State Control & $\sqrt{ }$ & $\sqrt{ }$ & $\sqrt{ }$ & $\sqrt{ }$ \\
\hline County FE & & $\sqrt{ }$ & & \\
\hline State FE & & $\sqrt{ }$ & & $\sqrt{ }$ \\
\hline Library FE & & $\sqrt{ }$ & & \\
\hline Year FE & & $\sqrt{ }$ & & $\sqrt{ }$ \\
\hline Observations & 113,993 & 113,993 & 128,729 & 128,729 \\
\hline $\mathrm{R} 2$ & 0.587 & 0.861 & & \\
\hline Adjusted R2 & 0.587 & 0.845 & & \\
\hline Akaike Inf. Crit. & & & $-15,200.60$ & $-20,896.79$ \\
\hline Bayesian Inf. Crit. & & & $-14,985.76$ & $-20,076.49$ \\
\hline
\end{tabular}

Notes: ${ }^{*} \mathrm{p}<0.1 ;{ }^{* *} \mathrm{p}<0.05 ;{ }^{* * *} \mathrm{p}<0.01$. Library Control for columns (1) and (2): Population, Master, Librarian, OtherPaid, HrsOpen, Visits, BookVolume, AudioCol, VideoCol, Computers, KidAttendance, Report1, Kap, SchDistrict, NonProfit. Library Control for columns (3) and (4): Master, Librarian, OtherPaid, Report1. State Control: Pincome, Age, Female, White, Black, Married, Immigrant, HighSchool, College, Unemploy. The use of county FE on the Tobit models makes it not possible to calculate the variance matrix which in turn does not allow the proper statistical inference. Nevertheless, the estimated signs are in line with those presented in this table, and these results are available upon request. Due to the computational power need to run these regressions, I used only state and year FE in the other set of tables. 
Table 2.3: Results in per capita values

\begin{tabular}{|c|c|c|c|c|}
\hline & \multicolumn{4}{|c|}{ Dependent variable: Donation } \\
\hline & \multicolumn{2}{|c|}{ OLS } & \multicolumn{2}{|c|}{ Tobit } \\
\hline & POLS & $\mathrm{FE}$ & Pooled & $\mathrm{FE}$ \\
\hline Local & $\begin{array}{c}0.019^{* * *} \\
(0.001)\end{array}$ & $\begin{array}{c}0.019^{* * *} \\
(0.002)\end{array}$ & $\begin{array}{c}0.046^{* * *} \\
(0.002)\end{array}$ & $\begin{array}{c}0.043^{* * *} \\
(0.002)\end{array}$ \\
\hline Local2 & $\begin{array}{c}-0.001^{* * *} \\
(0.0001)\end{array}$ & $\begin{array}{c}-0.001^{* * *} \\
(0.0001)\end{array}$ & $\begin{array}{c}-0.036^{* * *} \\
(0.002)\end{array}$ & $\begin{array}{c}-0.037^{* * *} \\
(0.003)\end{array}$ \\
\hline State & $\begin{array}{c}0.086^{* * *} \\
(0.008)\end{array}$ & $\begin{array}{c}0.033^{* *} \\
(0.013)\end{array}$ & $\begin{array}{c}0.093^{* * *} \\
(0.008)\end{array}$ & $\begin{array}{c}0.204^{* * *} \\
(0.012)\end{array}$ \\
\hline State2 & $\begin{array}{c}0.941^{* * *} \\
(0.036)\end{array}$ & $\begin{array}{c}1.172^{* * *} \\
(0.048)\end{array}$ & $\begin{array}{c}0.972^{* * *} \\
(0.038)\end{array}$ & $\begin{array}{c}0.669^{* * *} \\
(0.045)\end{array}$ \\
\hline Federal & $\begin{array}{c}0.743^{* * *} \\
(0.008)\end{array}$ & $\begin{array}{c}1.251^{* * *} \\
(0.009)\end{array}$ & $\begin{array}{c}0.754^{* * *} \\
(0.009)\end{array}$ & $\begin{array}{c}0.725^{* * *} \\
(0.009)\end{array}$ \\
\hline Federal2 & $\begin{array}{c}-0.270^{* * *} \\
(0.004)\end{array}$ & $\begin{array}{c}-0.470^{* * *} \\
(0.004)\end{array}$ & $\begin{array}{c}-0.275^{* * *} \\
(0.004)\end{array}$ & $\begin{array}{c}-0.263^{* * *} \\
(0.004)\end{array}$ \\
\hline NewEngland & $\begin{array}{c}0.003^{* * *} \\
(0.0002)\end{array}$ & & & \\
\hline Mideast & $\begin{array}{l}0.004^{* * *} \\
(0.0002)\end{array}$ & & & \\
\hline GreatLakes & $\begin{array}{l}0.001^{* * *} \\
(0.0002)\end{array}$ & & & \\
\hline logSigma & & & $\begin{array}{c}-4.065^{* * *} \\
(0.002) \\
\end{array}$ & $\begin{array}{c}-4.074^{* * *} \\
(0.002)\end{array}$ \\
\hline Library Control & $\sqrt{ }$ & $\sqrt{ }$ & $\sqrt{ }$ & \\
\hline $\begin{array}{l}\text { State Control } \\
\text { County FE }\end{array}$ & $\sqrt{ }$ & $\begin{array}{l}\sqrt{ } \\
\sqrt{ }\end{array}$ & $\sqrt{ }$ & \\
\hline State FE & & $\sqrt{ }$ & & $\sqrt{ }$ \\
\hline Library FE & & $\sqrt{ }$ & & \\
\hline Year FE & & $\sqrt{ }$ & & $\sqrt{ }$ \\
\hline Observations & 128,729 & 128,729 & 128,729 & 128,729 \\
\hline $\mathrm{R} 2$ & 0.106 & 0.555 & & \\
\hline Adjusted R2 & 0.106 & 0.511 & & \\
\hline Akaike Inf. Crit. & & & $-603,881.00$ & $-606,181.90$ \\
\hline Bayesian Inf. Crit. & & & $-603,666.20$ & $-605,361.60$ \\
\hline
\end{tabular}

Notes: ${ }^{*} \mathrm{p}<0.1 ;{ }^{* *} \mathrm{p}<0.05 ;{ }^{* *} \mathrm{p}<0.01$. Library Control: Population, Master, Librarian, OtherPaid, HrsOpen, Visits, BookVolume, AudioCol, VideoCol, Computers, KidAttendance, Report1, Kap. State Control: Pincome, Age, Female, White, Black, Married, Immigrant, HighSchool, College, Unemploy. 
Table 2.4: Outliers Results

\begin{tabular}{|c|c|c|c|c|}
\hline & \multicolumn{4}{|c|}{ Dependent variable: Donation } \\
\hline & \multicolumn{2}{|c|}{ OLS } & \multicolumn{2}{|c|}{ Tobit } \\
\hline & POLS & $\mathrm{FE}$ & Pooled & $\mathrm{FE}$ \\
\hline Local & $\begin{array}{c}-0.206^{* * *} \\
(0.002)\end{array}$ & $\begin{array}{c}0.055^{* * *} \\
(0.003)\end{array}$ & $\begin{array}{c}-0.041^{* * *} \\
(0.001)\end{array}$ & $\begin{array}{c}-0.050^{* * *} \\
(0.001)\end{array}$ \\
\hline Local2 & $\begin{array}{l}0.002^{* * *} \\
(0.00001)\end{array}$ & $\begin{array}{c}-0.001^{* * *} \\
(0.00003)\end{array}$ & $\begin{array}{l}0.003^{* * *} \\
(0.00002)\end{array}$ & $\begin{array}{l}0.003^{* * *} \\
(0.00002)\end{array}$ \\
\hline State & $\begin{array}{c}0.066^{* * *} \\
(0.004)\end{array}$ & $\begin{array}{c}-0.503^{* * *} \\
(0.008)\end{array}$ & $\begin{array}{c}0.343^{* * *} \\
(0.005)\end{array}$ & $\begin{array}{c}0.425^{* * *} \\
(0.006)\end{array}$ \\
\hline State2 & $\begin{array}{c}-0.004^{* * *} \\
(0.0001)\end{array}$ & $\begin{array}{c}0.003^{* * *} \\
(0.0002)\end{array}$ & $\begin{array}{c}-0.005^{* * *} \\
(0.0002)\end{array}$ & $\begin{array}{c}-0.006^{* * *} \\
(0.0002)\end{array}$ \\
\hline Federal & $\begin{array}{c}-0.340^{* * *} \\
(0.058)\end{array}$ & $\begin{array}{c}0.823^{* * *} \\
(0.049)\end{array}$ & $\begin{array}{c}2.535^{* * *} \\
(0.077)\end{array}$ & $\begin{array}{c}3.295^{* * *} \\
(0.081)\end{array}$ \\
\hline Federal2 & $\begin{array}{c}0.032 \\
(0.023)\end{array}$ & $\begin{array}{c}-0.314^{* * *} \\
(0.017)\end{array}$ & $\begin{array}{c}-0.069^{* *} \\
(0.031)\end{array}$ & $\begin{array}{c}-0.279^{* * *} \\
(0.031)\end{array}$ \\
\hline NewEngland & $\begin{array}{c}-0.016^{* * *} \\
(0.006)\end{array}$ & & & \\
\hline Mideast & $\begin{array}{c}0.009 \\
(0.007)\end{array}$ & & & \\
\hline GreatLakes & $\begin{array}{c}-0.025^{* * *} \\
(0.004)\end{array}$ & & & \\
\hline logSigma & & & $\begin{array}{c}-0.442^{* * *} \\
(0.002) \\
\end{array}$ & $\begin{array}{c}-0.454^{* * *} \\
(0.002) \\
\end{array}$ \\
\hline Library Control & $\sqrt{ }$ & $\sqrt{ }$ & $\sqrt{ }$ & \\
\hline $\begin{array}{l}\text { State Control } \\
\text { County FE }\end{array}$ & $\sqrt{ }$ & $\begin{array}{l}\sqrt{ } \\
\sqrt{ }\end{array}$ & $\sqrt{ }$ & \\
\hline State FE & & $\sqrt{ }$ & & $\sqrt{ }$ \\
\hline Library FE & & $\sqrt{ }$ & & \\
\hline Year FE & & $\sqrt{ }$ & & $\sqrt{ }$ \\
\hline Observations & 128,759 & 128,759 & 128,759 & 128,759 \\
\hline $\mathrm{R} 2$ & 0.699 & 0.896 & & \\
\hline Adjusted R2 & 0.699 & 0.886 & & \\
\hline Akaike Inf. Crit. & & & $245,125.20$ & $241,639.10$ \\
\hline Bayesian Inf.Crit. & & & $245,203.30$ & $242,332.40$ \\
\hline
\end{tabular}

Notes: ${ }^{*} \mathrm{p}<0.1 ;{ }^{* *} \mathrm{p}<0.05 ;{ }^{* *} \mathrm{p}<0.01$. Library Control: Population, Master, Librarian, OtherPaid, HrsOpen, Visits, BookVolume, AudioCol, VideoCol, Computers, KidAttendance, Report1, Kap. State Control: Pincome, Age, Female, White, Black, Married, Immigrant, HighSchool, College, Unemploy. 
Figure 2.1: Scatterplot of Donations and Government Revenues with and without outliers
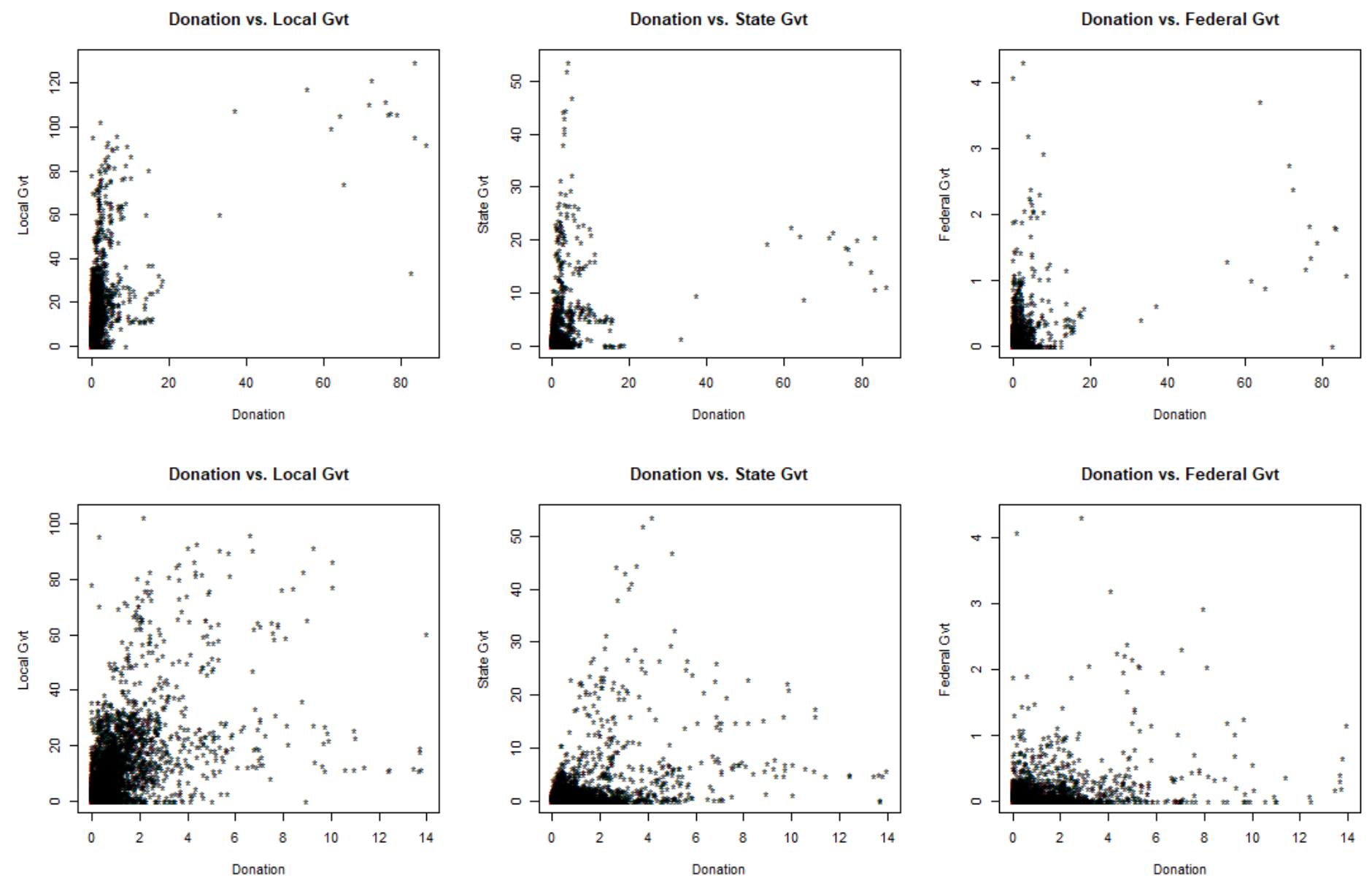

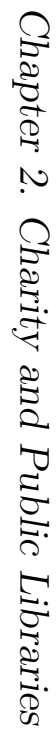

Note: The first row (above) contain the outliers and the second row (below) does not contain the outliers observations. 


\section{Chapter 3}

\section{Do Public Libraries Impact Local Labor Markets? Evidence from Appalachia}

\subsection{Introduction}

"Aiding job seekers is increasingly viewed as a vital role for public libraries, [...]"

Denise Davis, Director ALA in Jerrard (2009)

"[Aiding job seekers] is exactly what library should be doing. We're truly helping to bridge the digital divide. [...] It's natural for us to respond to a crisis in our community"

Pam Reese, Nashville Public Library in Jerrard (2009)

The idea that public libraries are only about books amid advances in technology, such as computers and the internet, has reduced the perceived importance of public libraries to local communities. Yet, in 2014, there were 9,305 public libraries in the United States, 3.9\% 
more public libraries than in 2010. These public libraries received 4.6 in-person visits per capita and $\$ 12.1$ billion in revenue, which, compared to 2010 , represents a $12 \%$ increase in in-person visits and $7 \%$ increase in revenues.

To remain relevant, public libraries have been adapting their services to match a new demand for services and materials (Goulding, 2006; Jerrard, 2009; Hunt, 2017). For example, public libraries have been expanding the number of programs and resources offered. In 2014, there were 4.5 million programs offered to adults and children, with 101.9 million attendees. This represented a $20 \%$ increase in the number of programs and $17 \%$ increase in the number of attendees compared to 2010. In terms of collection materials, in 2014 there were over 1.2 billion materials covering books, e-books, video, and audio. This corresponded to an increase of $29 \%$ of collection materials from 2010 . The composition of these materials also changed. In 2014 , books were $66.1 \%$ of the materials and e-books were $18.4 \%$, while in 2010 , books represented $86.4 \%$ of the materials and e-books $2 \%$ (The Institute of Museum and Libraries Services, 2016).

Library programs can be roughly divided into those for children and those for adults. Children's programs usually focus on book-related activities and entertainment activities. Adult programs focus on book activities, development of skills, and job search services. ${ }^{1}$ This chapter investigates the impact of these public library programs for children and adults and their participation on local labor markets outcomes, in particular, unemployment and labor force participation.

By focusing on public library programs, this chapter contributes to the literature of the effect of library use. The most relevant work in this literature is Bhatt (2010). She finds that an increase in library usage increases time spent reading, decreases time spent watching TV, and, for school-age children, increases homework completion rates. Betts (1995) and Farber and Gibbons (1996) utilize the possession of a library card at age 14 as a proxy for innate ability, but they did not evaluate the impact of library programs directly on wages. Further, Liu (2004) uses cross-section of countries and find that public libraries' literacy programs affect economic productivity measured by gross domestic product per capita.

\footnotetext{
${ }^{1}$ For a complete list of programs for school-age children visit http://www.ala.org/alsc/kickstart. For a list of services and programs for adults visit http://www.ala.org/tools/atoz/adultservices/adult_lib_svcs.
} 
This chapter also contributes to the active labor market programs (ALMP) literature that started with Ashenfelter (1978) and has been summarized by Heckman et al. (1999), Card et al. (2010), and Card et al. (2018), among others. Most public library adult programs have a focus on employment by helping develop new skills and finding jobs, similar to some of the government programs. Children's programs, on the other hand, can have indirect impact on local labor markets since parents may see public libraries as possible substitutes for daycare services (Smith and Rivera, 2004; Parrish, 2013). I contribute to this literature by focusing on (i) labor market programs that are overlooked, and (ii) rural areas that have lower levels of private and public labor market programs.

To evaluate the impact of the public library programs on local labor market outcomes, I combine datasets on county demographic characteristics and labor statistics with a novel dataset on public libraries. The Public Library System (PLS) dataset is an annual survey considered to be the census of public libraries in the United States. From the PLS, I collect data on the number of programs and program participation ${ }^{2}$, as well as a variety of information about each public library system. ${ }^{3}$

I restrict my analysis to the Appalachian region (Figure 3.1). Appalachia is a 205,000 square-mile area that follows the Appalachian Mountains, encompassing 13 states and 420 counties from southern New York to northern Mississippi (Appalachian Regional Commission, 2018). Appalachia covers remote rural areas and important urban areas as well. However, the region is mostly rural as $70 \%$ of its counties are non-metropolitan areas hosting $42 \%$ of its population (Appalachian Regional Commission, 2018; Stephens and Partridge, 2011). Appalachia is, and has been, a systematically lagging region associated with lower levels of labor force participation and higher levels of unemployment (Dorsey, 1991; Isserman and Rephann, 1993; Stephens and Deskins, 2018). For instance, this is the only region in the US with a dedicated policy-making commission, the Appalachian Regional Commission, which has been in place for over 50 years (Isserman and Rephann, 1993; Sayago-Gomez et al., 2018).

\footnotetext{
${ }^{2}$ Unfortunately, I cannot differentiate the extensive and intensive margins of public library use such as visits, attendance, circulation, among others. In other words, it is not possible to know how many different people attended these programs versus people who participated in the programs several times.

${ }^{3} \mathrm{~A}$ public library system is composed of a central library and its branches and bookmobiles.
} 
In terms of labor market, Appalachia has lower level of skill and suffer from "missing markets", i.e., the lack of high skilled labor and low returns to skill (Bollinger et al., 2011; Betz and Partridge, 2012). Also, the region has difficulties in attracting firms and retaining talent (Kahn, 2009). Thus, according to the ALMP literature, labor market programs should be effective in areas like Appalachia, that is, low skilled workers and those who have been unemployed for longer times. However, rural areas have a lower number of private and public labor market programs (Whitener, 1991; Green et al., 2003; Dunham et al., 2005). In addition, rural areas have lower levels of internet access, which is an important tool in today's labor market (Stenberg et al., 2009; Hampton, 2018). Thus, in such areas, public libraries could bridge this gap by offering both some labor market programs and internet access.

The identification comes from the within variation in the number of public library programs and program participation. However, these programs and their attendance can be endogenous to local labor markets. In other words, if public library programs are used as counter-cyclical policies, areas with high unemployment and low labor force participation may be more likely to have more adult programs and less children's programs, for example. This renders OLS estimation biased and unable to provide causal inference. Hence, I make use of an instrumental variable (IV) approach. More specifically, I use the number of librarians without master's degree and the amount of print material and computers for public use as instruments for the number of programs and the participation in these programs.

Libraries need both monetary and physical resources to promote programs and to attract patrons. Because public library funding comes mostly from local government, this is likely to be contemporaneously correlated with local labor markets. In turn, physical resources, such as the instruments, are less likely to be contemporaneously associated to local labor markets outcomes. On the one hand, although the flow of purchases of books and computers may change during recessions and booms, the volume of these resources in the library is less likely to change over time. This should be especially true for rural areas since patrons have reduced access to the internet and newer technologies such as e-readers and computers (Swan et al., 2013; Real and Rose, 2017). On the other hand, librarians without master's degree are usually those who offer and run programs, which should influence the selection 
into specific programs.

The results show adult and children's program and participation do not affect local labor market outcomes. These results are consistent across different specifications: quantile regressions show no difference across the distribution of labor market outcomes; using the Great Recession as an exogenous shock, there is no evidence that public library programs were more or less effective during this time; propensity score matching estimation also show no results from public library programs and participation.

However, spatial econometric estimations that account for spatial dependence and possible spillovers find suggestive results of indirect effect of library programs and participation. More specially, neighboring children's programs and participation have a positive effect on local labor market outcomes, i.e., decrease unemployment and increase labor force participation. Conversely, neighboring adult participation has a negative impact on local labor market outcomes.

These results are consistent with those in the active labor market program literature in that programs are largely ineffective. Given the aggregate nature of the data on public library programs, I am unable to explore neither individual nor program heterogeneous effects. The spatial econometric results are especially important in light of evidence that job search service assistance benefits participants at the expense of those who do not participate in such programs (Gautier et al., 2018).

With the recent trend of budget cuts to public library and the shift on public library focus to programs to help local communities, it is important to understand the effectiveness of public library programs. This is the first attempt to explore such questions. However, data limitations prevents the analysis on a more granular level that would allow to better understand possible effects and disentangle the mechanisms at work. Therefore, given the importance of public library in the American community (Wiegand, 2015) further research in the same vein of policy program evaluation is warranted. 


\subsection{Background}

\subsubsection{Public Library in the US}

Public libraries are usually taken for granted (Dubner, 2007). In the US, they started as privately-financed institutions that offered book-lending services. The Boston Public Library, founded in 1852, is the first to receive regular local government support. The expansion of public libraries was facilitated by donations of Andrew Carnegie, who helped fund the construction of over 1,500 public libraries in the US alone. However, the funds provided by Mr. Carnegie were to support the construction only, and not to be used in the endowment of these libraries. This led local governments into the public libraries business (Getz, 1980; Wiegand, 2015).

Public libraries have been, and are still, valued by patrons (Wiegand, 2015). According to the Pew Research Center, black and Hispanic populations, as well as students, job seekers, people without internet access at home are those who value public libraries services the most (Pew Research Center, 2013b, 2014). In turn, parents, more educated people, and the high income population are more likely to utilize public library services (Pew Research Center, 2013c, 2014). However, there is an overall lack of knowledge of the services public libraries offer (Bertot et al., 2012; Pew Research Center, 2013a,b; Rainie, 2016).

Nevertheless, public libraries are little studied by economists and policy scholars. ${ }^{4}$ The first economic study on public libraries is Tiebout and Willis (1965) who discuss the public nature of public libraries. In other words, public libraries are a public good that generates positive externalities, and thus have under provision of services. Most studies that followed can be classified into two strands: one focusing on demand, unit-costs and cost-benefit analysis (Pfister and Milliman, 1970; Goddard, 1970; Feldstein, 1976; Stratton, 1976; Getz, 1980; DeBoer, 1992; Hammond, 1999); and another focusing on the technical efficiency of public libraries (Sharma et al., 1999; Vitaliano, 1997, 1998; Hemmeter, 2006; Ferreira Neto and Hall, 2018). ${ }^{5}$

\footnotetext{
${ }^{4}$ For instance, Knight and Nourse (1969) commission's report asked for further studies on public libraries instead of providing recommendations per se. Even though there are numerous journals specialized on libraries, a focus on the impact or policy outcome of libraries is scarce.

${ }^{5}$ Other papers used similar methods to study public libraries in other countries like Australia (Worthing-
} 
On the other hand, there are few studies that analyze the impact of public libraries on different outcomes. For instance, using an instrumental variable approach, Bhatt (2010) finds that an increase in library use increases time spent reading, decreases time spent watching TV and for children at schools, it increases homework completion rates. Fujiwara et al. (2017) use a survey of users and non-users of public libraries in the UK showing a positive association between public library use and self-reported happiness and health status. Conversely, Ferreira Neto (2018) studies the impact of government funding on private donations to public libraries in the US, and finds suggestive results of a crowd-in effect.

In terms of the labor market, the research on the impact of public libraries is scarce. For instance, Stine (2008) look at how volunteer workers impact the demand for labor from public libraries. He finds a complementary relationship between volunteer work and library staff. Further, although not focused on library use per se, Betts (1995) and Farber and Gibbons (1996) use information of library card holding to proxy for unobservable ability in a Mincerian wage regression. To the best of my knowledge, this is the first study to investigate the impact of public library programs on local labor market outcomes.

\subsubsection{Active Labor Market Programs}

The ALMP literature mostly focuses on the government programs created by the Area Redevelopment Act in 1961 (LaLonde, 2003), and has been extensively summarized by Greenberg et al. (2003), Heckman et al. (1999), Card et al. (2010), and Card et al. (2018), among others. Most adult programs do focus on labor market outcomes, which is similar to some of the private and public programs that have been in place for over several decades.

LaLonde (2003) divides government training and employment programs into four types: skill development, work experience, employability development, and job development. Brown and Koettl (2015), in turn, classify these programs into those focusing on labor supply, labor demand, and matching. Public library programs targeting adults that are associated with labor market outcomes can be summarized in three areas: job search assistance, human capital enhancement, and entrepreneurial and small business programs (Bertot et al., 2012; ton, 1999), Belgium (Witte and Geys, 2011), and the United Kindgom (Hammond, 2002, 2009). 
Rainie, 2016). Therefore, public library programs are related to programs in skill development and employability development following the former classification and all of the latter classification.

The results that are most relevant for this chapter are the ineffectiveness of public sector employment programs, and the positive impact of job search assistance programs. There are also some heterogeneity in the results depending on the investigated outcomes, the program type, and the treatment groups, with larger effects for women and those who were unemployed longer (Heckman et al., 1999; Kluve, 2010; Card et al., 2010, 2018). Also, Card et al. (2018) argue that ALMP have larger effects during recession times, i.e., low growth and high unemployment. These results, then, should help put the results found for public libraries into perspective. One caveat is that while this literature utilizes individual level data, this is not available for public library programs, and the analysis in this chapter is at a more aggregated level.

\subsection{Data}

\subsubsection{Labor Market Outcomes}

Unemployment and labor force participation data come from the Local Area Unemployment Statistics (LAUS) provided by the Bureau of Labor Statistics (BLS). I follow the BLS and define the labor force participation rate as the ratio between labor force status and population over 15 years old. Table 3.1 provides summary statistics for all counties in the US (Panel A) and those in Appalachia (Panel B).

Similar to previous studies Appalachian counties have lower labor force participation and higher unemployment compared to other counties in the US. Table 3.1 also splits the counties into those with and without a public library system. In both Appalachia and the US, counties with a public library system have, on average, lower unemployment and higher labor force participation. 


\subsubsection{The Public Library Survey}

Information from public libraries come from the Public Library Survey (PLS). The PLS has been collected annually since 1988 covering approximately 9,300 public library systems comprising over 17,000 individual public library outlets (central library, branches, and bookmobiles). The survey covers all 50 states, the District of Columbia, and outlying territories and has over a $98 \%$ rate of response. As such it is considered the census of public libraries in the US (The Institute of Museum and Library Services, 2018).

Figure 3.2 shows the number of public library systems per county. As discussed in Getz (1980) and Wiegand (2015), New England stands out in terms of number of public libraries in each county. The same is true in Illinois, specially around Chicago and Pennsylvania, home of Andrew Carnegie. Arkansas, Minnesota, Mississippi, and Georgia are the states with the most counties without a public library system.

The Institute of Museum and Library Services (IMLS) reports that no governmental program is attached to the PLS, and it is not mandatory. Therefore, there are no incentives for over or underreporting information provided, which covers several features including location, administrative data such as staff information, revenue by source, expenditures, among others; and service and use, such as circulation, visits, programs, materials, among others. Until 2005, the PLS was collected by the Institute of Education Sciences and the US Department of Education. Since 2006, the survey has been collected by the IMLS. Since 2009 the PLS has reported the rate of response per state. Appalachian states have a 100\% response rate, with the exception of Pennsylvania that had an average response rate of $99.6 \%$.

The variables of interest are the adult and children library programs. The PLS collects data on the number programs and participation in these programs, and reports these data for all (total) programs, children's programs, and since 2009 young adult programs. Ideally the PLS would record not only the total number of programs and participation, but also the repeated participation in these programs. Unfortunately, as this is not the case I am unable to differentiate between extensive and intensive margins of public library use.

For my analysis, I calculate the number of adult programs as the difference in total programs from children's programs. Similarly, the participation in adult programs is the dif- 
ference in total program attendance minus children's program attendance. Further, because data on these programs largely begins in 2006, I restrict my sample to the years from 2006 to 2015. Figures 3.3 and 3.4 show the average number of adults and kids programs in 2006 and 2015 for Appalachia.

As described in section 3.1, the number of programs and participation are likely endogenous to labor market outcomes. Thus, I use other library information as instruments for the number of programs and participation. More specifically, I use the number of print materials, the number of computer with internet access for public use, and number of librarians without a American Library Association certified Master's degree. These variables proxy for quality and capacity of running programs and attracting patrons. To take into account the heterogeneity due to location and density, all library variables are scaled by county population.

\subsubsection{Demographic and Industry Characteristics}

Other independent variables used are demographic and industry controls. Demographic control, namely, race, gender, age composition comes from the Census Bureau through the Area Health Resource Files. Ideally, I would like to incorporate some measure of education. However, there is no dataset that I know of that systematically collects education attainment at the county level on a yearly basis. The closest to this would be the American Community Survey, but the statistics provided are for a 5-year period. The average weekly wage for total manufacturing and total services come from the Quarterly Census of Employment and Wages (QCEW) provided by the BLS.

Table 3.2 provides the descriptive statistics for the variables used in the econometric model. In terms of demographics, most of the population is white (91\%), female (50.5\%), and between 15 to 64 years (65.5\%). For industry and employment, the weekly wage in manufacturing (\$779) is larger than the weekly wage in services (\$528). With regards to library programs and participation, there are on average more than two times the number of children's programs (210) than adult programs (103). Also, the participation in children's programs $(5,403)$ is on average about three times the participation in adult programs $(1,742)$. 


\subsection{Empirical Strategy}

To investigate the effects of public library programs on the local labor market outcomes, I estimate the following model:

$$
y_{c t}=\beta_{0}+\beta_{1} A d u_{c t}+\beta_{2} K i d_{c t}+X_{c t} \delta+\mu_{c}+\theta_{t}+\varepsilon_{c t}
$$

where $y$ is either the unemployment rate $(U R)$ or labor force participation rate $(L F P R)$ in county $c$, in year $t$. The library program variables, $A d u$ and $K i d$, measure either the average number of programs per capita, or average participation per capita, for adults and children's programs respectively.

The vector $X$ contains relevant control variables following the previous literature that explains local labor market outcomes (Partridge and Rickman, 1997; Partridge, 2001; Stephens and Deskins, 2018). Hence, I include demographic controls, such as race (Cajner et al., 2017), gender (Black et al., 2014) and age composition (Hipple, 2016); as well as industry controls (Partridge, 2001), such as the average weekly wage in manufacturing and services as a whole, and the lagged unemployment rate (Blanchard and Katz, 1992). $\mu_{c}, \theta_{t}$ are county and year fixed effects (Pesaran, 2006); and $\varepsilon_{c t}$ is an error term.

The coefficients of interest in this model are $\beta_{1}$ and $\beta_{2}$, which should be interpreted as the percentage point impact of the additional program or participation per person on the unemployment rate and labor force participation rate. If $\beta_{1}$ and $\beta_{2}$ are positive, this suggests that public library programs have a negative impact on the unemployment rate as larger participation and more programs would be associated with a higher unemployment rate. Conversely, a negative sign would suggest positive impact on the unemployment rate. The opposite is true for the labor force participation rate. That is, if $\beta_{1}$ and $\beta_{2}$ are positive (negative), then public library programs will have a positive (negative) impact on the labor force participation rate.

However, OLS estimation probably does not provide causal evidence on the impact of public library programs on local labor markets outcomes. These estimations are likely biased due to an endogeneity problem. As the local labor markets changes, i.e., unemployment rate and labor force participation rate increase (decrease), libraries can respond to these changes 
by offering (cutting) programs or by incentivizing (discouraging) participation (Jerrard, 2009; Hunt, 2017). If there is a procyclical relationship between public libraries programs and unemployment rate the OLS estimates would be biased upward, or vice versa.

Therefore, I use an instrumental variable (IV) approach. Because I have two endogenous variables, adult and children's programs, at least two instruments are needed for proper identification. In this chapter I use the linear constant effect instrumental variable model. Therefore, for the instrument to be valid, it must affect the dependent variable only through the endogenous independent variable. To provide unbiased estimation, the instrument must be strongly correlated with the endogenous variable, but uncorrelated with the error term, hence uncorrelated with the dependent variable itself (Angrist and Pischke, 2009; Cunningham, 2018). The two sets of instruments used are: (i) the average number of computers with internet for public use (Computer) and the average number of librarians without a Master's degree per person (Librarian) for program participation; and (ii) the average number of computers with internet for public use (Computer) and the average number of print materials per person (Books) for the number of programs. Formally:

$$
\begin{gathered}
\mathbb{E}[\text { Instrument }, \varepsilon]=0 \\
\mathbb{E}[\text { Instrument }, v]=0 \\
\operatorname{cov}(\text { Endogenous }, \text { Computer }) \neq 0 \\
\operatorname{cov}(\text { Endogenous }, \text { Librarian }) \neq 0 \\
\operatorname{cov}(\text { Endogenous }, \text { Books }) \neq 0
\end{gathered}
$$

where Instrument $=\{$ Computer, Librarian,Books $\}$ and Endogenous $=\{$ Adu, Kid $\}$.

The unbiased effect of public library programs on the local labor markets is estimated using a two-stage least square framework, in which in the first stage (Eq. 3.4), the instruments are regressed on the endogenous variables, also controlling for other control variables used in the second stage, as well as the various fixed effects.

$$
\begin{aligned}
& A d u_{c t}=\alpha_{0}+\text { Instrument }_{c t} \alpha_{1}+X_{c t} \phi+\mu_{c}+\eta_{s}+\theta_{t}+v_{c t} \\
& \text { Kid }_{c t}=\alpha_{0}+\text { Instrument }_{c t} \alpha_{1}+X_{c t} \phi+\mu_{c}+\eta_{s}+\theta_{t}+v_{c t}
\end{aligned}
$$


In the second stage (Eq. 3.5), the predicted value $\widehat{A d u_{c t}}$ and $\widehat{K i d_{c t}}$ are used in lieu of the observed values. Thus, the estimated equations are:

$$
y_{c t}=\beta_{0}+\beta_{1} \widehat{A d u_{c t}}+\beta_{2} \widehat{K i d_{c t}}+X_{c t} \delta+\mu_{c}+\theta_{t}+\varepsilon_{c t}
$$

\subsubsection{Instrument Validity}

The endogeneity problem arising in Equation 3.1 is due to the possible simultaneity of unemployment rate and labor force participation rate with the number of public library programs and their attendance. Public libraries are not randomly assigned to location throughout the country; however, most of them have been in place for over five decades at minimum. ${ }^{6}$ Further, public libraries can be used as a policy instrument providing more or fewer programs in response to changes in the local labor markets.

Equations 3.2 and 3.3 show the two assumptions that must hold for identification when using an IV approach, i.e., the exclusion restriction and existence of a "first stage". To properly identify the effect of public library programs on local labor markets, I need a set of instruments that are uncorrelated with the local labor markets, but highly correlated with the number of programs and participation in these programs. I argue that the capacity of offering a program and attracting patrons meet both criteria.

To offer a program, public libraries require both an appropriate level of funding and availability of resources for the programs. According to the IMLS, in 2014, approximately $85.2 \%$ of public library funding came from local government, while the remaining part comes from state government (7\%), federal government (0.4\%), and other sources $(7.4 \%)$ (The Institute of Museum and Libraries Services, 2016). Since most revenue stems from local government, this funding is expected to be contemporaneously correlated with regional business cycles and local labor markets. This is corroborated by several reports of public libraries across the country losing part of their revenue due to struggling local governments (Blau, 2011; Warburton, 2013; Smith, 2015; Kelley, 2015; Davis, 2015; Stepleton, 2015; Woods, 2015; Cleaver,

\footnotetext{
${ }^{6}$ According to Stratton (1976), in 1972 there were 7,109 public libraries in the country which corresponds to over $78 \%$ of the libraries that existed in 2014 according to the Institute of Museum and Library Services (IMLS, 2016).
} 
2015). ${ }^{7}$

Public libraries also require trained staff, physical space, and materials (print and computers), at a minimum, in order to offer such programs. A priori, because these variables are related to the capacity of the library, they should not be contemporaneously correlated with regional business cycles, but they should be strongly correlated to the programs offered by the library. Such features make these variable good candidates for instruments.

First, I focus on the exclusion hypothesis. According to the American Library Association (2018) there are six jobs in a public library: pages, library assistants or technicians, librarians, library managers, library directors and other professionals. ${ }^{8}$ Thus, given the several occupations in public libraries, librarians should be less susceptible to business cycle fluctuations. In addition, education (bachelors and masters degree) is shown to be a determinant in job security (Hashimoto and Raisian, 1985; College Board, 2017).

As for the number of computers and print materials, they are a stock variable. Even though the flow of purchases of computers and books by libraries vary with budgetary allocation, libraries store such materials to provide their different services. Also, there is a physical constraint in the number of books and computers public libraries can have. Therefore, given the stock feature of these variables, they should be contemporaneously uncorrelated to both unemployment rate and labor force participation rate. Table 3.3 shows OLS regression of the instruments on local labor market outcomes, conditional on the control variables and fixed effects used in the main analysis. The results suggest these variables are not contemporaneously correlated, satisfying the exclusion restriction.

Now I turn my attention to the existence of a first stage, that is, the correlation of instruments and endogenous variables. The set of variables chosen proxy for the quality of programs and number of programs. Since librarians without masters degree are those

\footnotetext{
${ }^{7}$ In response to budget cuts, several proposal for levies have the introduced in the ballots to specifically fund public libraries, either creating, renewing or increasing existing levies. These proposals have been mostly successful in the the ballots (Howard Fleeter \& Associates, 2017; Spokane Public Library, 2017; Hrin, 2018; Fallows, 2014).

${ }^{8} \mathrm{~A}$ page is usually a part-time job and is responsible to keep items in order. A library assistant can be either part-time or full-time job and generally performs clerical duties. Librarians are full-time employees that decide the items that are needed, offer programs and training, and help people in general. Library managers are middle managers responsible for daily operations, while library directors are the main leadership in the library. For more details on visit http://www.ala.org/educationcareers/careers/librarycareerssite/typesofjobs.
} 
responsible to provide programs, and programs for job seekers usually require computer and internet access, these should be good predictors of participation. For instance, people may select into those programs in which the librarian is better prepared, more approachable, or have a better reputation.

Additionally, the more inputs (computers and books) that are available, the easier it should be to provide output in the form of programs. Table 3.4 reports the first-stage estimation results, providing evidence of strong correlation between library programs and the instruments. Since I have more than one endogenous variable, I compute the heteroskedasticrobust conditional F-Statistics, reported in Table 3.4. The estimated F-Statistics show values above 12 for all adults and children's program and participation, suggesting the set of instruments used are good instruments (Stock and Yogo, 2005).

\subsection{Results}

Table 3.5 shows the OLS and IV results for two sets of regressions. The first two columns report the results for the unemployment rate, while the last two columns report the results for the labor force participation rate. Panel A focuses on the number of programs, and Panel B focuses on the participation.

The OLS results show no statistical significant correlation between adult or children's programs and participation with the unemployment rate. Conversely, children's programs and participation are positively and statistically correlated with the labor force participation rate. As previously discussed, the OLS estimation does not provide causal inference in this case as library programs and participation are likely endogenous to labor market outcomes. The IV results show that neither adult nor children's programs and participation affect unemployment rate, similar to the OLS results, but also do not affect the labor force participation.

Public library programs (and participation) may not help people find jobs, however they should reduce the cost of joining the labor market, especially for adult programs. Adults programs focus on job services and skills training (Bertot et al., 2012; Hunt, 2017). These programs are designed to help adults find and keep their jobs which should positively impact 
labor force participation and negatively impact unemployment. This should be particularly true in Appalachia, where people have less access to formal training (Haaga, 2004; Pollard and Jacobsen, 2017) and to the internet at home (Stenberg et al., 2009).

However, similar to active labor market programs (Heckman et al., 1999; LaLonde, 2003; Card et al., 2018), these programs may suffer from a selection bias. In other words, these programs target low-skilled and/or first-time workers (Goulding, 2006; Jerrard, 2009) who may have a higher cost of joining the labor market, especially in rural areas such as Appalachia. Thus, individual level data would be ideal to disentangle these heterogenous effects, but it is not available for public library programs.

In light of the discussion so far, at least three possible extension or robustness tests come to mind, considering the limitations data on public library program and participation impose. Building on the different costs associated with joining and remaining in the labor market, it may be the case that the OLS estimations are not representative of the distribution of labor market outcomes. Therefore, I use quantile regressions to test this hypothesis.

In addition, if public libraries see their programs, especially those for adults, as a response to a crisis, it may be that they are more effective during recession times, similar to active labor market programs (Card et al., 2018). Hence, I use the Great Recession as an exogenous shock to evaluate if these programs were more effective in this time. Also, even though Appalachia should receive special attention as demonstrated so far, it may be that Appalachian counties without libraries are not good control group for those with a public library system. Thus, I make use of propensity score matching to create a different control group.

\subsubsection{Robustness Checks}

\section{Quantile Regression}

One possible concern is that the cost associated with joining the labor market and/or finding a job varies along the distribution of labor force participation and unemployment. In other words, it may be less costly to join the labor market in areas with higher labor force participation and easier to find a job in areas with low unemployment. To test this hypothesis, I use quantile regression as described in Koenker and Bassett (1978), and re- 
estimate equation 3.1 for different quantiles of the dependent variable. Particularly, I focus on the 10th, 25th, 50th, 75th and 90th quantiles.

Figure 3.5 summarizes the results using for the OLS estimates and Figure 3.6 summarizes the results using the predicted value of the first stage (Equation 3.4) instead. The results in both cases show that the estimates along the distribution are not statistically different from the OLS ones, which corroborates the main results. ${ }^{9}$ Because the predicted values are used in Figure 3.6 in lieu of observable values, one can expect larger confidence intervals for the quantile estimates, however, the point estimates lie within the OLS estimates confidence interval, which reduces this concern.

\section{Great Recession Shock}

According to the active labor market programs literature, these programs are more successful during a recession (Card et al., 2018). Public library programs' main focus is on job search assistance, which is likely more demanded in economic downturns. As reported by several outlets, since the Great Recession (2008-2009), several public libraries have lost part of their revenues from local governments due to budgetary issues. As a consequence, libraries had to reduce their hours of operation to remain in business (Blau, 2011; Warburton, 2013; Smith, 2015; Kelley, 2015; Davis, 2015; Stepleton, 2015; Woods, 2015; Cleaver, 2015).

Ergo, I use the Great Recession as an exogenous shock that caused some libraries to reduce their hours of operations. The Great Recession had heterogenous effects throughout the country impacting counties in different ways, even in more similar regions like Appalachia. If public library programs are similar to those privately and publicly provided elsewhere, during the Great Recession counties that had their public libraries more affected, i.e., had their hours of operation reduced, should see worst labor market outcomes than those not affected. Formally:

$$
y_{c t}=\gamma_{0}+\gamma_{1} R H_{c t}+\gamma_{2} G R_{t}+\gamma_{3}(R H * G R)_{c t}+X_{c t} \delta+\mu_{c}+\theta_{t}+\varepsilon_{c t}
$$

where $R H$ is an indicator variable that equals one if the public library operated less hours

\footnotetext{
${ }^{9}$ Complete results are available upon request.
} 
in year $t$ than $t-1$ and $G R$ is an indicator variable for the Great Recession, i.e., equals one for the years of 2008 and 2009. The remaining variables and parameters are similar to those in equation 3.1. The parameter of interest in this case is $\gamma_{3}$. In addition, I include the adult and children's program and interact with $\gamma_{3}$ to test the for different effects from these programs.

Note that this is not a traditional difference-in-difference analysis since the reduction of hours is an endogenous decision given public libraries' budget constraint. Further, there is no expectation that libraries with and without reduced hours of operation had similar pretrends in terms of programs and participation. Nevertheless, given the aggregate nature of the data, this analysis yields extra evidence on the possible effect of public library programs and participation on local labor market outcomes.

The results for this analysis are presented in table 3.6. Panel A shows the estimated results for Equation 3.6; Panel B and Panel $\mathrm{C}$ show the results using the interaction of number of programs and participation with the exogenous shock parameter $\left(\gamma_{3}\right)$. Overall, similar to previous analysis, there is no evidence that public library programs impact labor market outcomes. Even in recession times, when according to Card et al. (2018) labor market programs are more effective, there is still no evidence of such, at least on an aggregate level. Individual outcomes may vary, but as previously mentioned I am unable to test it with the current data.

\section{Propensity Score Matching}

The instrumental variable approach generates exogenous variation that enables the causal identification of public library programs and participation on local labor markets outcomes. However, it may be the case that "the control group" for Appalachian counties with public library systems are not ideal. For instance, public library systems are not randomly assigned in the country, and there can be other unobservables that systematically bias the results.

To try to control for this possible selection problem, I employ a propensity score matching approach to create another "control group" for Appalachian counties with public library systems. Intuitively, the idea is to find comparable counties to those in Appalachia that have a public library system in terms of observable characteristics that determine, directly 
or indirectly, labor market outcomes. Thus, if a public library is the only difference between these counties, its effect would be identifiable when comparing these groups.

The propensity score matching method removes the necessity of using instrumental variables, given the matching should have controlled for the unobservables that could affect the public library programs and local labor markets. Ichimura and Taber (2001) show that the propensity score matching is a special case of instrumental variable approach. Wooldridge (2016), on the other hand, argues that using instrumental variables for matching purposes increases inconsistency.

Therefore, I use socio-demographic characteristics as well as industry characteristics, more specially the employment location quotient $\left(L Q_{e}\right)$. The $L Q_{e}$ accounts for the relative importance of the industry to the county. Using the predictions from a logit model in which the dependent variable is the presence of a public library system, I select the observations closest to those in Appalachia with a public library system, or "treated counties".

Table 3.7 has the comparison of means between treated (Appalachian counties with public library) and control groups. Panel A shows the matching variables while Panel B shows the local labor market outcomes. Table 3.8 presents the estimated results for a empirical model similar to Equation 3.1. The results corroborate previous analysis so far, providing extra evidence that, on an aggregate level, public library programs and participation do not affect local labor market outcomes.

\subsubsection{Spatial Spillovers}

Halleck Vega and Elhorst (2016) note three stylized facts about local unemployment rates: the strong correlation over time (Blanchard and Katz, 1992), the parallel to national trends (Pesaran, 2006), and the correlation across space (Patacchini and Zenou, 2007). So far in this chapter, only the first two issues were taken into account, as time-lagged unemployment rate and year fixed effects have been included in the regressions. Thus, in this subsection I take a step further and (i) control for spatial dependence of local labor market outcomes, and (ii) evaluate the spillover effects of library programs.

Two methods to take the three features of local labor market outcomes have been pro- 
posed. On the one hand, Bailey et al. (2016) proposes to deal with these issues in a two-step procedure, in which the aggregate shocks are de-factored from local labor market outcomes, and the resulting variables modeled using spatial econometrics. On the other hand, Halleck Vega and Elhorst (2016) argue against this method, proposing another one that deals with the three issues concomitantly. I follow more closely the method proposed by Halleck Vega and Elhorst (2016).

A general formulation of spatial econometric models is

$$
\begin{aligned}
& y=\rho W y+X \beta+W X \gamma+\varepsilon \\
& \varepsilon=\lambda W \varepsilon+v
\end{aligned}
$$

where $W$ is the spatial weight matrix used to spatially lag the variable of interest. The spatial autogressive model (SAR) includes only the $\rho$ parameter, the spatial error model (SEM) includes only the $\lambda$ parameter, and the spatial lag of X model (SLX) includes only the $\gamma$ parameter. LeSage and Pace (2014b) argue that applied works such as this, should focus on two models only: the spatial Durbin model (SDM), which is the linear combination of SAR and SEM models, and the spatial Durbin error model (SDM), which is the nested version of the SEM and SLX models. The former includes both $\rho$ and $\gamma$ parameters, while the latter includes $\lambda$ and $\gamma$ parameters.

The key difference between the SDM and SDEM models is that, while the former is a global spillover specification, the latter is a local spillover one. In other words, the global spillover implies an endogenous feedback effect, which are spillovers from higher-order neighbors as well (LeSage and Pace, 2014b). LeSage and Pace (2014b) argue that global spillover phenomena should be rarer than local spillovers. For the case of local labor markets, this should be specially true (Patacchini and Zenou, 2007; Halleck Vega and Elhorst, 2016), and hence I estimate the SDEM model. An extra benefit of the SDEM model lies in the fact that the spatially-lagged variables can be interpreted as the indirect effect while the non-spatially-lagged are the direct effect.

Because of the endogeneity issue discussed throughout the chapter, the spatial estimations would still be biased with respect to library programs. Therefore, I use the IV estimator 
described in Millo and Piras (2012). Table 3.9 shows the results for the SDEM model with and without an IV approach. The estimated models use a contiguity weight matrix of type queen. ${ }^{10}$

First I consider the results for unemployment rate. Neither adult nor children's program or participation have a direct impact on the unemployment rate. Conversely, the results show that neighboring adult programs and participation increase the unemployment rate, while children's program and participation decreases it. The results for labor force participation are similar to those for the unemployment rate. In particular, neighboring adult participation decreases labor force participation, whilst neighboring children's program and participation increases it.

The additional neighboring children program per 1,000 people decreases the unemployment rate in 0.06 percentage points and increase labor force participation in 0.312 percentage points, or 186 people. The additional participant per 1,000 people in neighboring adult program increases the unemployment rate in 0.002 percent points and decreases labor force participation in 0.007 percent points. Conversely, the additional participant per 1,000 people in neighboring children's program decreases the unemployment rate in 0.001 percentage points and increases labor force participation in 0.009 percentage points, or 5 people.

Intuitively, although public library programs targeting adults focus on job search activities, they also supply entertainment and skill-developing programs. People may select into the latter programs more often if the cost of searching remain too high. In this case, job-seekers would try and look for programs that would help them develop their skills before (re)joining the labor market, or else at programs that increase their leisure. As for the indirect effect of children's programs, as parents are hired or join the labor market actively looking for jobs in neighboring counties, they may make use of the neighboring public libraries for their children if they see public libraries as substitutes for day care (Noble, 1988; Smith and Rivera, 2004) which can be prohibitively expensive, especially for lower-skilled workers.

In sum, the spatial econometric analysis corroborates the previous section in that public

\footnotetext{
${ }^{10}$ LeSage and Pace (2014a) argue that the specification of the weight matrices should not have large impact on estimates and inferences.
} 
library programs and participation have no direct effect on labor market outcomes. Nevertheless, it suggests that there is an indirect effect, which is more prominent for children's program.

\subsection{Conclusion and Policy Implication}

The objective of this chapter is to investigate the effect of public library programs in local labor markets. More specially, I focus on the impact of the number of children's and adult programs and participation on unemployment and labor force participation. I restrict my analysis to the Appalachian region because: it is a lagging region, suggesting a high level of unemployment and poverty; mostly rural, which implies fewer private and public labor market programs and lower levels of internet access; and with unique features in terms of labor market outcomes, in particular, lower levels of labor force participation.

Since the provision of public library programs can be endogenous to local business cycles, I use an instrumental variable approach. The results provide no evidence that public library programs and participation affect local labor market outcomes, at least in an aggregate level. These results are robust across different specifications and control groups.

Spatial econometric estimates, however, show suggestive result that there is an indirect effect of public library programs and participation, specially for children's program. In particular, neighboring children's program and participation decrease the unemployment rate and increase the labor force participation, while neighboring adult participation increase the unemployment rate and decreases labor force participation.

Policy implications are two-fold. First, given the recent trend in budget cuts from public libraries and the shift on provision of services, the results are suggestive that, overall, public libraries are not able to help people find and keep jobs. This may vary within the population (gender, race, education level, etc.) but in this chapter I am unable to test for these heterogenous effects. Therefore, public libraries must be aware of their budget allocation in order to be the most effective for their communities. Further, different programs can be more or less effective, but data limitation also does not allow me to test for these effects.

Secondly, in light of the spatial econometric models, children's program have a short-term 
impact on local labor markets, however, in neighboring counties. This reinforces children's programs importance, since they can also have a long-term effect on local labor market via educational outcomes (Bhatt, 2010), which is an important predictor of long-term employment, income, among others. Thus, since public libraries already offer on average five times more children's than adult programs, the cost of increasing the former should be smaller. Also, these programs are more likely to have larger impacts in their communities over time.

The caveats of this chapter are the aggregate nature of the data and the inability to disentangle intensive and extensive margins. Future studies should focus on acquiring, ideally, data at the individual level, and identifying the patrons that participate in each library program. Also, focusing on the type of library programs is important to make results more comparable to studies on private and public active labor market programs. The use of experimental methods can be helpful in identifying the mechanisms that help individuals join the labor force and through which programs these mechanisms work better. 
Table 3.1: Summary Statistics for Local Labor Market Outcome Variables

\begin{tabular}{|c|c|c|c|}
\hline Statistic & $\begin{array}{c}\text { All } \\
\text { Counties }\end{array}$ & $\begin{array}{c}\text { With } \\
\text { Libraries }\end{array}$ & $\begin{array}{l}\text { Without } \\
\text { Libraries }\end{array}$ \\
\hline \multicolumn{4}{|l|}{ Panel A: United States } \\
\hline Unemployment Rate & $\begin{array}{c}6.96 \\
(2.98)\end{array}$ & $\begin{array}{c}6.82 \\
(2.95)\end{array}$ & $\begin{array}{c}7.52 \\
(3.06)\end{array}$ \\
\hline Labor Force Participation Rate & $\begin{array}{l}54.73 \\
(8.73)\end{array}$ & $\begin{array}{l}60.30 \\
(8.37)\end{array}$ & $\begin{array}{l}57.45 \\
(9.70)\end{array}$ \\
\hline $\mathrm{N}$ & 31,093 & 24,861 & 6,232 \\
\hline \multicolumn{4}{|l|}{ Panel B: Appalachia } \\
\hline Unemployment Rate & $\begin{array}{c}8.19 \\
(2.80)\end{array}$ & $\begin{array}{c}8.11 \\
(2.75)\end{array}$ & $\begin{array}{c}8.47 \\
(2.93)\end{array}$ \\
\hline Labor Force Participation Rate & $\begin{array}{l}54.39 \\
(6.85)\end{array}$ & $\begin{array}{l}54.18 \\
(6.85)\end{array}$ & $\begin{array}{l}55.76 \\
(6.66)\end{array}$ \\
\hline $\mathrm{N}$ & 4,200 & 3,649 & 551 \\
\hline
\end{tabular}

Standard deviations in parenthesis. There is information missing for seven counties for the US, all in the state of Louisiana in the year 2006. 
Table 3.2: Descriptive Statistics

\begin{tabular}{|c|c|c|c|c|c|}
\hline Statistic & $\mathrm{N}$ & Mean & St. Dev. & Min & Max \\
\hline \multicolumn{6}{|l|}{ Demographic: } \\
\hline Population & 4,200 & 59,688 & 97,311 & 2,138 & $1,231,527$ \\
\hline Percent Female & 4,200 & 0.505 & 0.017 & 0.325 & 0.564 \\
\hline Percent Asian & 4,200 & 0.006 & 0.010 & 0.000 & 0.118 \\
\hline Percent Black & 4,200 & 0.065 & 0.111 & 0.0001 & 0.826 \\
\hline Percent Other Race & 4,200 & 0.002 & 0.007 & 0.000 & 0.151 \\
\hline Percent Two or more Races & 4,200 & 0.011 & 0.005 & 0.002 & 0.046 \\
\hline Percent American Indian & 4,200 & 0.004 & 0.015 & 0.0001 & 0.280 \\
\hline Percent Latin & 4,200 & 0.027 & 0.032 & 0.002 & 0.339 \\
\hline Percent White & 4,200 & 0.911 & 0.114 & 0.154 & 0.993 \\
\hline Percent $<15$ yo & 4,200 & 0.178 & 0.022 & 0.035 & 0.288 \\
\hline Percent 15-64yo & 4,200 & 0.655 & 0.026 & 0.548 & 0.780 \\
\hline Percent $>64$ yo & 4,200 & 0.167 & 0.032 & 0.059 & 0.334 \\
\hline \multicolumn{6}{|l|}{ Industry/Employment: } \\
\hline Avg. Weekly Wage for Total Manufacturing (\$100s) & 4,200 & 7.787 & 2.153 & 0.000 & 21.427 \\
\hline Avg. Weekly Wage for Total Services $(\$ 100$ s) & 4,200 & 5.279 & 1.073 & 0.000 & 11.853 \\
\hline Unemployment & 4,200 & 2,070 & 3,347 & 36 & 48,202 \\
\hline Labor Force & 4,200 & 28,366 & 49,901 & 796 & 653,196 \\
\hline \multicolumn{6}{|l|}{ Library: } \\
\hline Avg. Adult Participation (1000s) & 4,200 & 1.988 & 4.602 & 0.000 & 67.848 \\
\hline Avg. Number of Adult Programs & 4,200 & 117.277 & 256.262 & 0.000 & 3,988 \\
\hline Avg. Children's Participation (1000s) & 4,200 & 6.229 & 12.778 & 0.000 & 181.539 \\
\hline Avg. Number of Children's programs & 4,200 & 240.276 & 456.139 & 0.000 & 5,480 \\
\hline Avg. Number of Print Materials (1000s) & 4,200 & 75.160 & 121.865 & 0.000 & 1,204 \\
\hline Avg. Number of Computers & 4,200 & 27.554 & 46.665 & 0.000 & 498.000 \\
\hline Avg. Number of Librarians without M.A. & 4,200 & 2.381 & 4.478 & 0.000 & 47.880 \\
\hline Adult Participation Per 1,000 People & 4,200 & 43.844 & 86.928 & 0.000 & 1,376 \\
\hline Adult Programs Per 1,000 People & 4,200 & 2.750 & 5.417 & 0.000 & 97.316 \\
\hline Children Participation Per 1,000 People & 4,200 & 131.214 & 203.051 & 0.000 & 2,822 \\
\hline Children's Programs Per 1,000 People & 4,200 & 5.884 & 10.582 & 0.000 & 136.264 \\
\hline
\end{tabular}


Table 3.3: Exclusion Restriction for Books and Masters

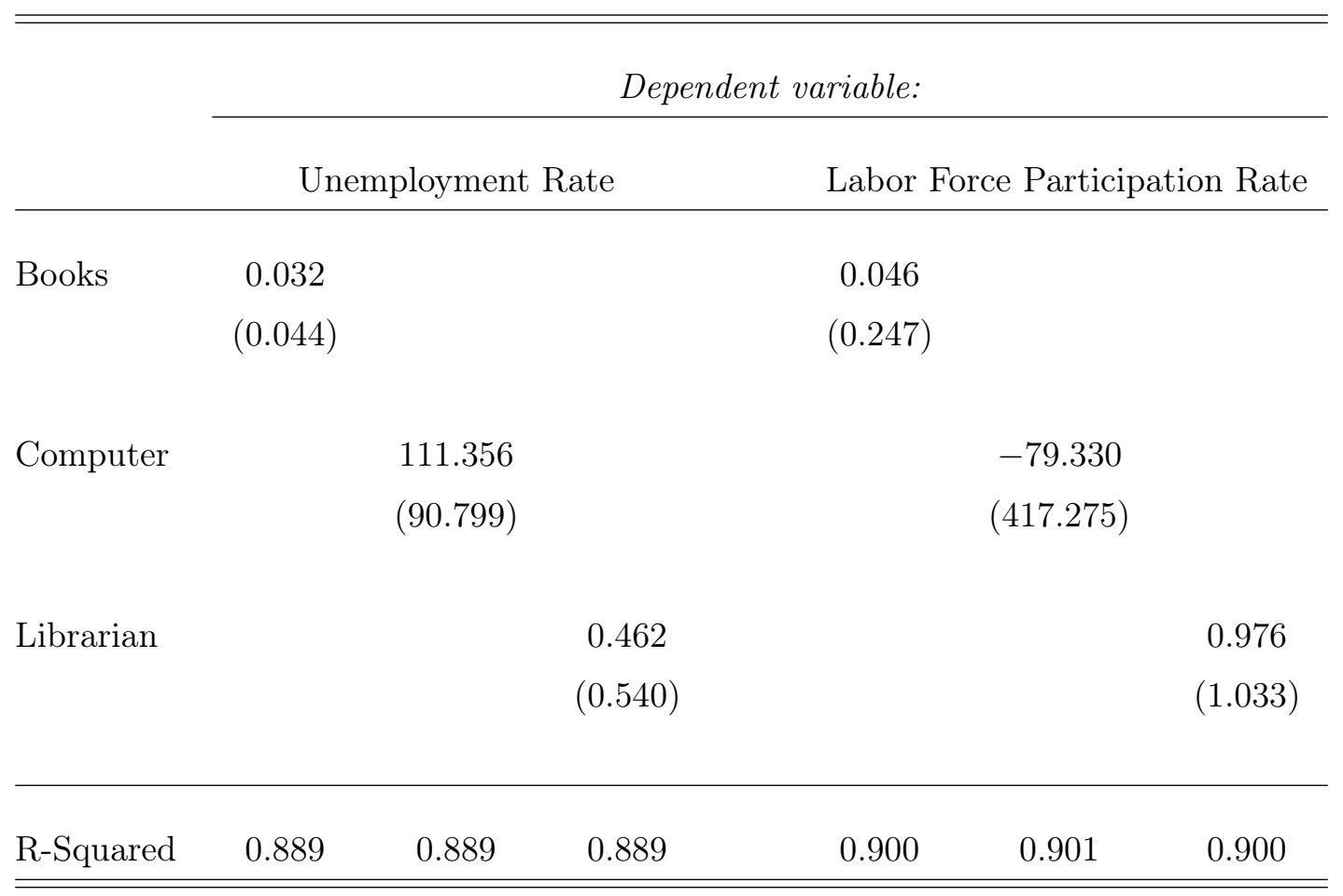

Clustered standard errors in parentheses. ${ }^{*} \mathrm{p}<0.1 ;{ }^{* *} \mathrm{p}<0.05 ;{ }^{* * *} \mathrm{p}<0.01 . \quad$ Note: $\mathrm{N}=4,200$ in all regressions. Controls: percent population asian, black, american indian, other race, latin, and two plus race, percent female, percent population between 15 and 64 years old, lagged unemployment rate, time-lagged average weekly wage on manufacturing, and service; year, county and state fixed effects. 
Table 3.4: First Stage Results for Adults and children's programs

\begin{tabular}{|c|c|c|c|c|}
\hline & \multicolumn{4}{|c|}{ Dependent variable: } \\
\hline & \multicolumn{2}{|c|}{ Adults } & \multicolumn{2}{|c|}{ Children } \\
\hline & Programs & Participation & Programs & Participation \\
\hline \multirow[t]{2}{*}{ Books } & 0.514 & & $2.142^{* * *}$ & \\
\hline & $(0.510)$ & & $(0.387)$ & \\
\hline \multirow[t]{2}{*}{ Computer } & $2.747^{* * *}$ & $50.919^{* * *}$ & $1.309^{* *}$ & $69.049^{* * *}$ \\
\hline & $(0.800)$ & $(11.908)$ & $(0.619)$ & $(19.009)$ \\
\hline \multirow[t]{2}{*}{ Librarian } & & -40.782 & & $216.015^{* *}$ \\
\hline & & $(41.306)$ & & $(86.170)$ \\
\hline R-Squared & 0.723 & 0.738 & 0.865 & 0.876 \\
\hline Robust Conditional F-Statistics & 18.4 & 12.9 & 12.3 & 13.0 \\
\hline
\end{tabular}

Clustered standard errors in parentheses. ${ }^{*} \mathrm{p}<0.1 ;{ }^{* *} \mathrm{p}<0.05 ;{ }^{* * *} \mathrm{p}<0.01$. Note: $\mathrm{N}=4,200$ in all regressions. Controls: percent population asian, black, american indian, other race, latin, and two plus race, percent female, percent population between 15 and 64 years old, time-lagged unemployment rate, time-lagged average weekly wage on manufacturing, and service; year, county and state fixed effects. 
Table 3.5: Results for Library Programs and Participation on Unemployment Rate and Labor Force Participation Rate

\begin{tabular}{|c|c|c|c|c|}
\hline & \multicolumn{4}{|c|}{ Dependent variable: } \\
\hline & \multicolumn{2}{|c|}{ Unemployment Rate } & \multicolumn{2}{|c|}{ Labor Force Participation Rate } \\
\hline & OLS & IV & OLS & IV \\
\hline \multicolumn{5}{|c|}{ Panel A: Programs } \\
\hline \multirow[t]{2}{*}{ Adults } & -0.001 & 0.061 & 0.034 & -0.065 \\
\hline & $(0.010)$ & $(0.068)$ & $(0.021)$ & $(0.168)$ \\
\hline \multirow[t]{2}{*}{ Children } & -0.008 & -0.002 & $0.054^{* *}$ & 0.057 \\
\hline & $(0.006)$ & $(0.044)$ & $(0.026)$ & $(0.122)$ \\
\hline R-Squared & 0.866 & 0.862 & 0.901 & 0.899 \\
\hline \multicolumn{5}{|c|}{ Panel B: Participation } \\
\hline \multirow[t]{2}{*}{ Adults } & 0.0002 & 0.001 & 0.001 & -0.007 \\
\hline & $(0.001)$ & $(0.004)$ & $(0.001)$ & $(0.009)$ \\
\hline \multirow[t]{2}{*}{ Children } & -0.0001 & 0.002 & $0.002^{*}$ & 0.004 \\
\hline & $(0.001)$ & $(0.002)$ & $(0.001)$ & $(0.004)$ \\
\hline R-Squared & 0.866 & 0.863 & 0.900 & 0.897 \\
\hline
\end{tabular}

Clustered standard errors in parentheses. ${ }^{*} \mathrm{p}<0.1 ;{ }^{* *} \mathrm{p}<0.05 ;{ }^{* * *} \mathrm{p}<0.01$. Note: $\mathrm{N}=4,200$ in all regressions. Controls: percent population asian, black, american indian, other race, latin, and two plus race, percent female, percent population between 15 and 64 years old, lagged unemployment rate, time-lagged average weekly wage on manufacturing, and service; year, county and state fixed effects. Instruments: average print materials per capita, average computers for public use per capita, and average librarians without master's degree per capita. 
Table 3.6: Exogenous Shock Results for Library Programs and Participation on Unemployment Rate and Labor Force Participation Rate

\begin{tabular}{|c|c|c|}
\hline & \multicolumn{2}{|c|}{ Dependent variable: } \\
\hline & Unemployment Rate & Labor Force Participation Rate \\
\hline \multicolumn{3}{|l|}{ Panel A: Dummy Variable } \\
\hline \multirow[t]{2}{*}{ Reduced Hour } & -0.029 & -0.161 \\
\hline & $(0.058)$ & $(0.118)$ \\
\hline \multirow[t]{2}{*}{ Reduced Hour $*$ Great Recession } & 0.195 & -0.178 \\
\hline & $(0.143)$ & $(0.280)$ \\
\hline R-Squared & 0.861 & 0.914 \\
\hline \multicolumn{3}{|l|}{ Panel B: Programs } \\
\hline \multirow[t]{2}{*}{$\overline{\text { Adults }}$} & 0.082 & -0.153 \\
\hline & $(0.109)$ & $(0.282)$ \\
\hline \multirow[t]{2}{*}{ Children } & 0.061 & -0.007 \\
\hline & $(0.137)$ & $(0.417)$ \\
\hline \multirow[t]{2}{*}{ Reduced Hour*Adults*Great Recession } & -0.002 & -0.019 \\
\hline & $(0.039)$ & $(0.060)$ \\
\hline \multirow[t]{2}{*}{ Reduced Hour $*$ Children $*$ Great Recession } & -0.001 & -0.003 \\
\hline & $(0.014)$ & $(0.030)$ \\
\hline R-Squared & 0.849 & 0.909 \\
\hline \multicolumn{3}{|l|}{ Panel C: Participation } \\
\hline \multirow[t]{2}{*}{ Adults } & 0.003 & -0.013 \\
\hline & $(0.005)$ & $(0.013)$ \\
\hline \multirow[t]{2}{*}{ Children } & 0.004 & 0.004 \\
\hline & $(0.003)$ & $(0.006)$ \\
\hline \multirow[t]{2}{*}{ Reduced Hour $*$ Adults $*$ Great Recession } & -0.002 & 0.001 \\
\hline & $(0.002)$ & $(0.004)$ \\
\hline \multirow[t]{2}{*}{ Reduced Hour $*$ Children $*$ Great Recession } & 0.001 & -0.001 \\
\hline & $(0.001)$ & $(0.002)$ \\
\hline R-Squared & 0.852 & 0.907 \\
\hline
\end{tabular}

Clustered standard errors in parentheses ${ }^{*} \mathrm{p}<0.1 ;{ }^{* *} \mathrm{p}<0.05 ;{ }^{* * *} \mathrm{p}<0.01$. Note: $\mathrm{N}=3,649$ in all regressions. Controls: percent population asian, black, american indian, other race, latin, and two plus race, percent female, percent population between 15 and 64 years old, time-lagged unemployment rate, time-lagged average weekly wage on manufacturing, and service; year, county and state fixed effects. Instruments: average print materials per capita, average computers for public use per capita, and average librarians without master's degree per capita. 
Table 3.7: Comparison of Means Between Groups

\begin{tabular}{|c|c|c|c|c|}
\hline & \multicolumn{2}{|c|}{ Control } & \multicolumn{2}{|c|}{ Treated } \\
\hline & Mean & St. Dev & Mean & St. Dev. \\
\hline \multicolumn{5}{|l|}{ Panel A: Matching Variables } \\
\hline \multicolumn{5}{|l|}{ Demographic: } \\
\hline Population & 70,255 & 262,290 & 64,088 & 103,078 \\
\hline Percent Female & 0.51 & 0.015 & 0.51 & 0.017 \\
\hline Percent White & 0.91 & 0.112 & 0.92 & 0.106 \\
\hline Percent Black & 0.06 & 0.109 & 0.06 & 0.102 \\
\hline Percent 15-64yo & 0.66 & 0.031 & 0.66 & 0.025 \\
\hline Percent SNAP Recipients & 0.13 & 0.086 & 0.14 & 0.100 \\
\hline Personal Income per capita & 26,007 & 12,349 & 26,385 & 9,927 \\
\hline \multicolumn{5}{|l|}{ Employment Location Quotient: } \\
\hline Construction & 0.84 & 0.635 & 0.82 & 0.562 \\
\hline Education and Health Services & 1.01 & 0.444 & 1.02 & 0.421 \\
\hline Financial Activities & 0.57 & 0.254 & 0.58 & 0.254 \\
\hline Information & 0.47 & 0.429 & 0.47 & 0.481 \\
\hline Leisure and Hospitality & 0.88 & 0.423 & 0.86 & 0.398 \\
\hline Manufacturing & 1.74 & 1.117 & 1.63 & 1.146 \\
\hline Trade, Transportation, and Utilities & 0.97 & 0.236 & 0.97 & 0.247 \\
\hline Natural Resources and Mining & 1.57 & 2.504 & 1.95 & 3.617 \\
\hline Professional and Business Services & 0.46 & 0.404 & 0.44 & 0.319 \\
\hline \multicolumn{5}{|l|}{ Other: } \\
\hline Avg. Weekly Wage for Total Manufacturing & 8.00 & 2.061 & 7.95 & 2.206 \\
\hline Avg. Weekly Wage for Total Services & 5.35 & 1.196 & 5.32 & 1.092 \\
\hline One-year Lagged Unemployment Rate & 8.11 & 3.116 & 8.09 & 2.786 \\
\hline \multicolumn{5}{|l|}{ Outcome Variables: } \\
\hline Unemployment Rate & 8.07 & 2.947 & 8.18 & 2.773 \\
\hline Labor Force Participation Rate & 59.44 & 7.147 & 54.18 & 6.842 \\
\hline
\end{tabular}

N: 3649. Treated group are counties in Appalachia with a public library system. Control group are counties in the US without a public library system matched to "treated group" using propensity score matching method. 
Table 3.8: Propensity Matching Results for Library Programs and Participation on Unemployment Rate and Labor Force Participation Rate

Dependent variable:

Unemployment Rate

Labor Force Participation Rate

Panel A: Programs

Adults

0.003

$-0.003$

(0.006)

Children

$-0.001$

$-0.009$

(0.003)

(0.014)

R-Squared

0.889

0.927

Panel B: Participation

Adults

0.0001

$-0.002^{*}$

(0.0004)

(0.001)

Children

$-0.00002$

0.001

$(0.0003)$

(0.001)

R-Squared

0.889

0.927

Clustered standard errors in parentheses ${ }^{*} \mathrm{p}<0.1 ;{ }^{* *} \mathrm{p}<0.05 ;{ }^{* * *} \mathrm{p}<0.01$. Note: $\mathrm{N}=7,298$ in all regressions. Controls: percent population asian, black, american indian, other race, latin, and two plus race, percent female, percent population between 15 and 64 years old, time-lagged unemployment rate, time-lagged average weekly wage on manufacturing, and service; year, county and state fixed effects. 
Table 3.9: Spatial Dependence and Spillovers of Library Program and Participation

\begin{tabular}{|c|c|c|c|c|}
\hline & \multicolumn{4}{|c|}{ Dependent variable: } \\
\hline & \multicolumn{2}{|c|}{ Unemployment Rate } & \multicolumn{2}{|c|}{ Labor Force Participation Rate } \\
\hline & SDEM & SDEM-IV & SDEM & SDEM-IV \\
\hline \multicolumn{5}{|l|}{ Panel A: Programs } \\
\hline \multirow{2}{*}{$\overline{\text { Adults }}$} & $0.010^{* *}$ & 0.411 & -0.020 & $-1.453^{*}$ \\
\hline & $(0.004)$ & $(0.251)$ & $(0.015)$ & $(0.848)$ \\
\hline \multirow[t]{2}{*}{ Children } & -0.002 & -0.208 & 0.012 & 0.730 \\
\hline & $(0.003)$ & $(0.133)$ & $(0.008)$ & $(0.450)$ \\
\hline \multirow[t]{2}{*}{ Spatially Lagged Adults } & 0.016 & $0.073^{*}$ & 0.012 & -0.184 \\
\hline & $(0.011)$ & $(0.039)$ & $(0.035)$ & $(0.136)$ \\
\hline \multirow[t]{2}{*}{ Spatially Lagged Children } & $-0.019^{* * *}$ & $-0.062^{* *}$ & $0.162^{* * *}$ & $0.312^{* * *}$ \\
\hline & $(0.006)$ & $(0.030)$ & $(0.018)$ & $(0.103)$ \\
\hline \multirow[t]{2}{*}{$\lambda$} & $0.107^{* * *}$ & 0.151 & $0.200^{* * *}$ & 0.153 \\
\hline & $(0.023)$ & & $(0.022)$ & \\
\hline \multicolumn{5}{|l|}{ Panel B: Participation } \\
\hline \multirow[t]{2}{*}{$\overline{\text { Adults }}$} & 0.0005 & 0.002 & -0.001 & -0.016 \\
\hline & $(0.0003)$ & $(0.002)$ & $(0.001)$ & $(0.010)$ \\
\hline \multirow[t]{2}{*}{ Children } & $-0.0003^{* *}$ & 0.00003 & $0.002^{* * *}$ & -0.003 \\
\hline & $(0.0001)$ & $(0.001)$ & $(0.0004)$ & $(0.003)$ \\
\hline \multirow[t]{2}{*}{ Spatially Lagged Adults } & $0.002^{* * *}$ & $0.002^{* * *}$ & $-0.006^{* *}$ & $-0.007^{* * *}$ \\
\hline & $(0.001)$ & $(0.001)$ & $(0.002)$ & $(0.003)$ \\
\hline \multirow[t]{2}{*}{ Spatially Lagged Children } & $-0.001^{* * *}$ & $-0.001^{* * *}$ & $0.009^{* * *}$ & $0.009^{* * *}$ \\
\hline & $(0.0003)$ & $(0.0003)$ & $(0.001)$ & $(0.001)$ \\
\hline \multirow[t]{2}{*}{$\lambda$} & $0.107^{* * *}$ & 0.111 & $0.202^{* * *}$ & 0.193 \\
\hline & $(0.023)$ & & $(0.022)$ & \\
\hline
\end{tabular}

Robust standard errors in parentheses ${ }^{*} \mathrm{p}<0.1 ;{ }^{* *} \mathrm{p}<0.05 ;{ }^{* * *} \mathrm{p}<0.01$. Note: $\mathrm{N}=4,200$ in all regressions. Controls: percent population asian, black, american indian, other race, latin, and two plus race, percent female, percent population between 15 and 64 years old, time-lagged unemployment rate, time-lagged average weekly wage on manufacturing, and service; spatially-lagged controls, year, county and state fixed effects. Spatial weight matrix defined as a contiguity matrix of type queen. Instruments: average print materials per capita, average computers for public use per capita, and average librarians without master's degree per capita. 
Figure 3.1: The Appalachia Region

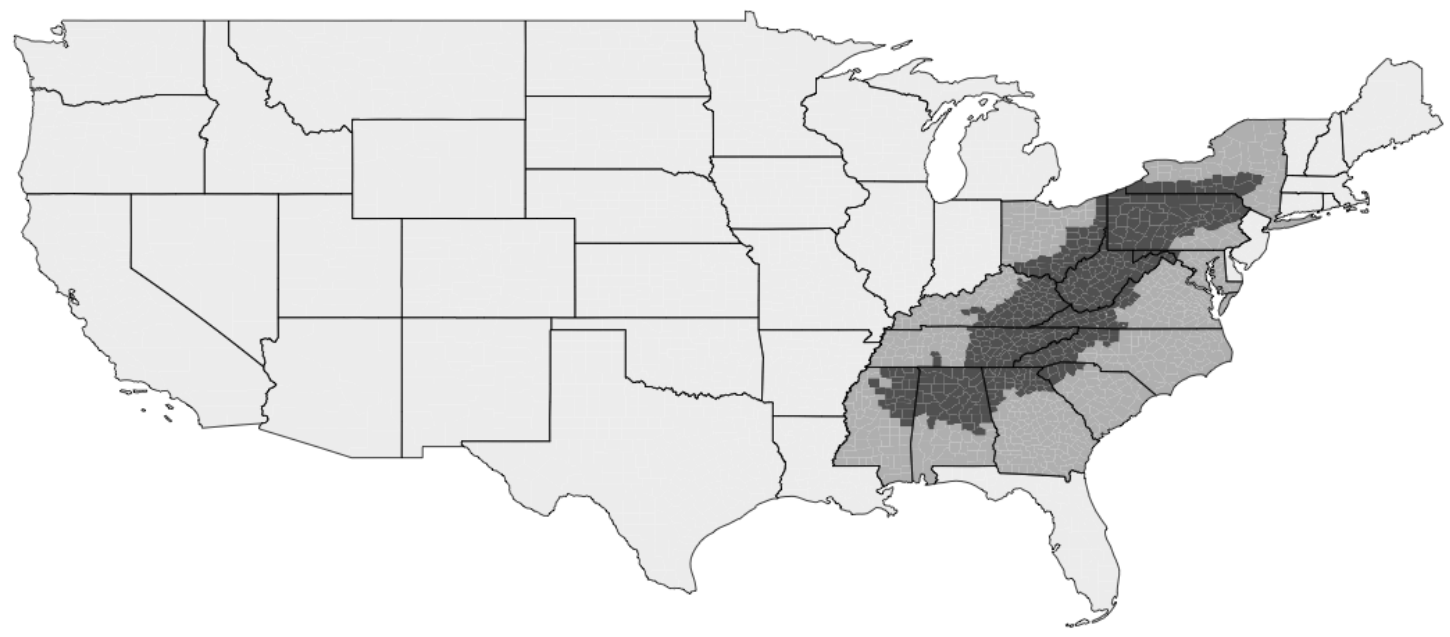

States that have any Appalachian county are in medium gray shade, and the Appalachia region is an dark gray shade. 
Figure 3.2: Number of Libraries per County for the US

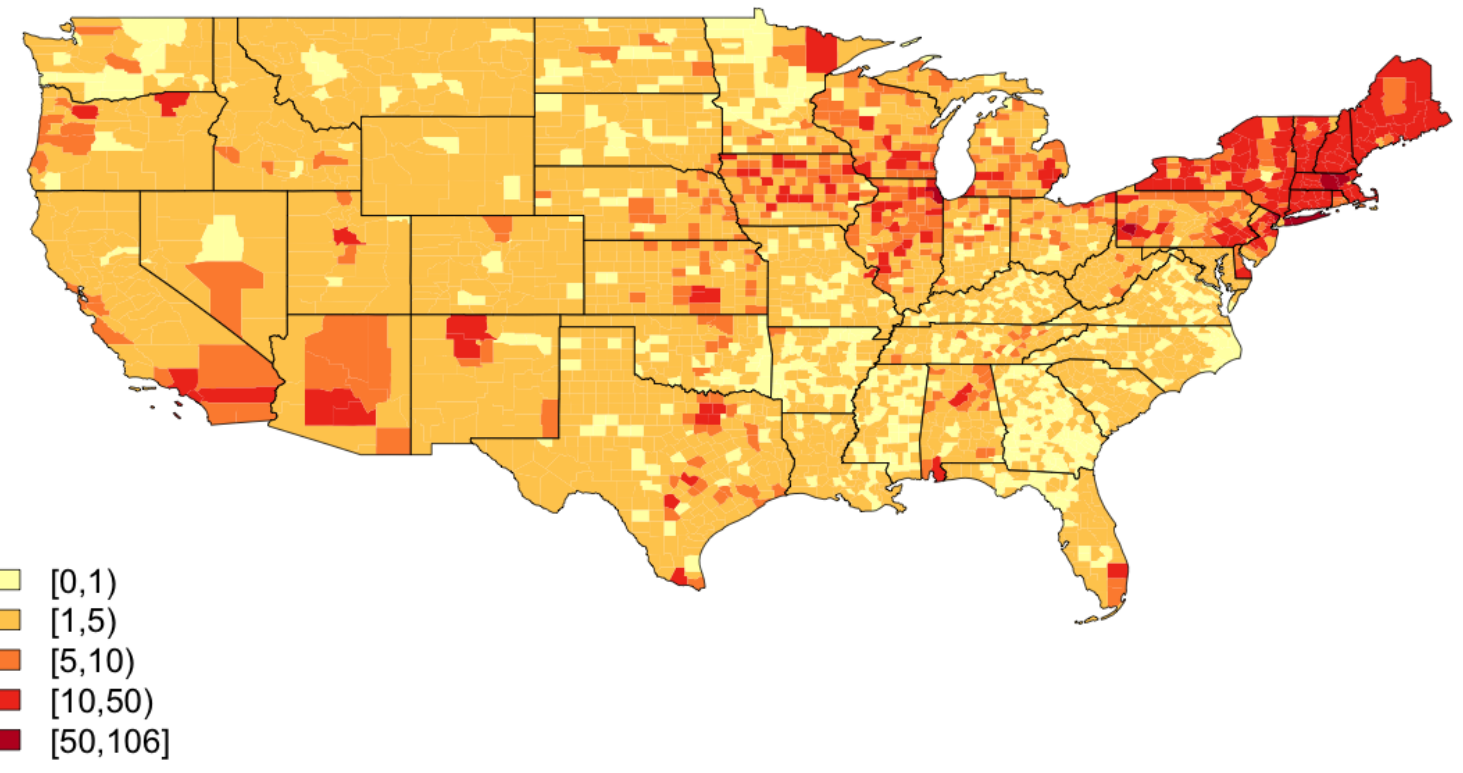


Figure 3.3: Number of Adults and Children Program in 2006
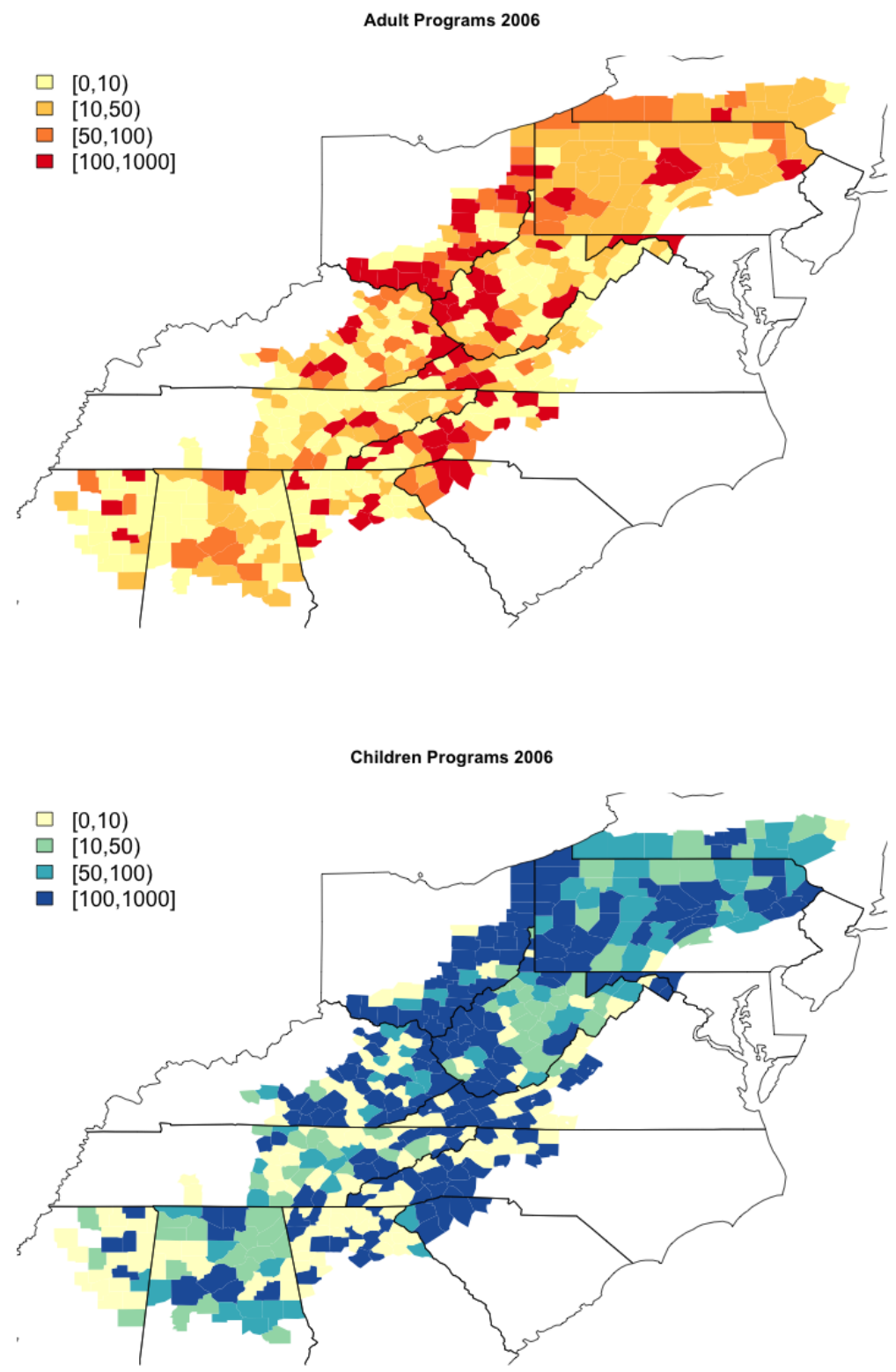
Figure 3.4: Number of Adults and Children Program in 2015
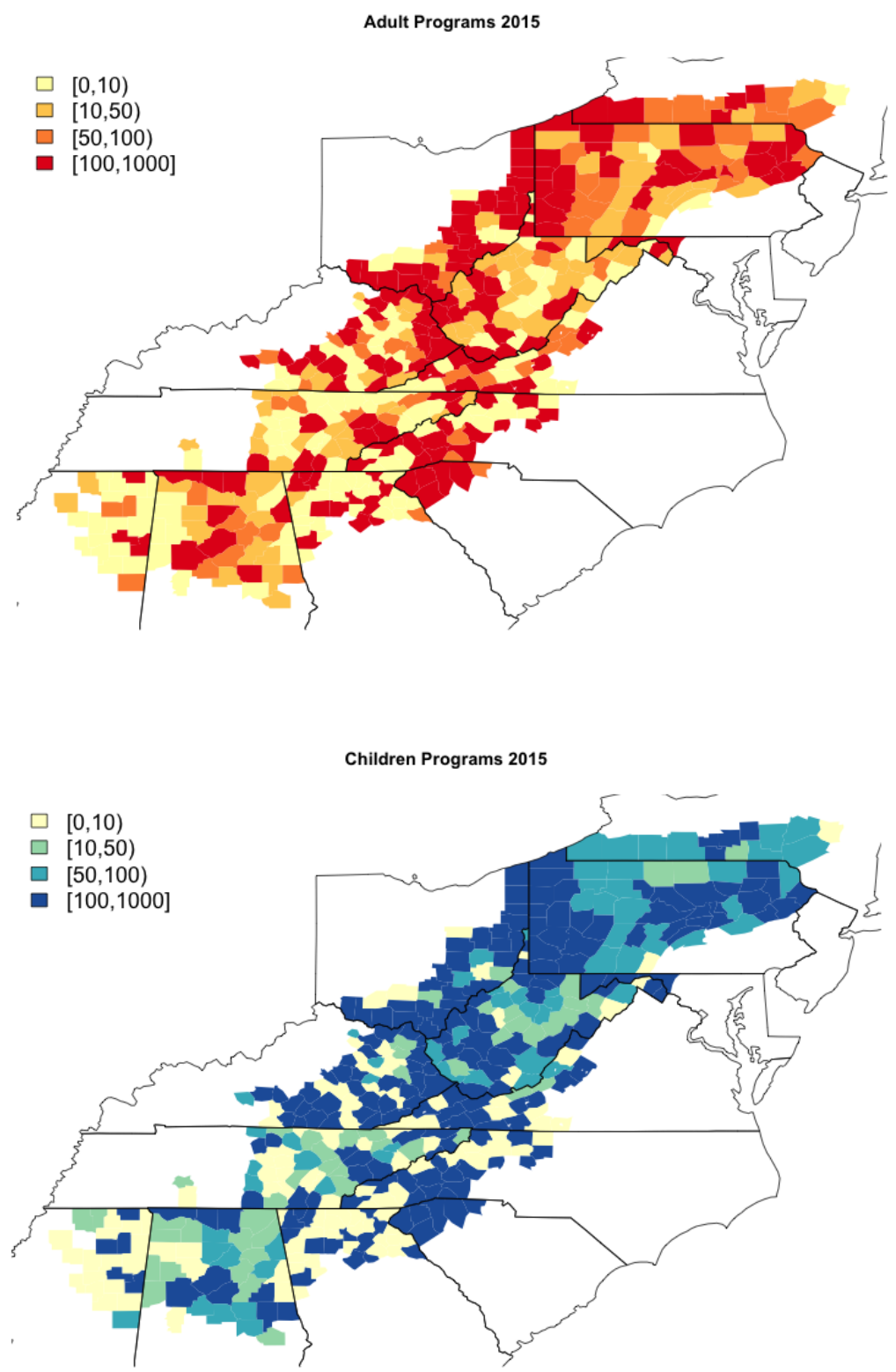
Figure 3.5: Quantile Regression Results using OLS

Panel A: Unemployment Rate

A1: Number of Programs
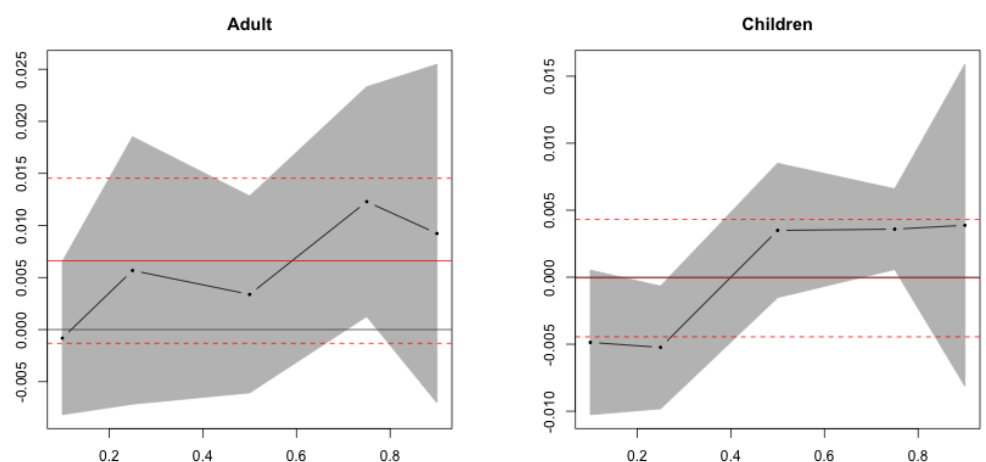

PanelPanel B: Labor Force Participation Rate
A2: Participation

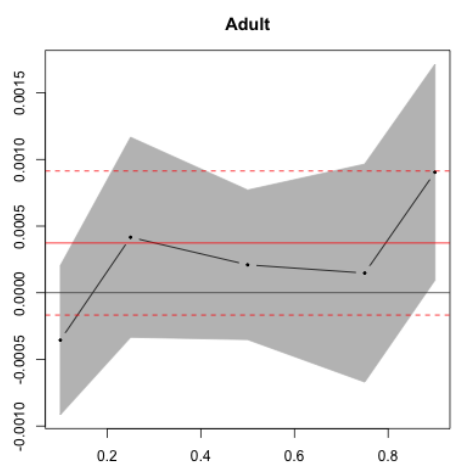

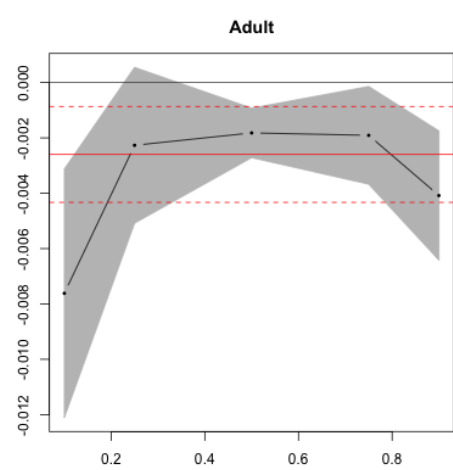

Children

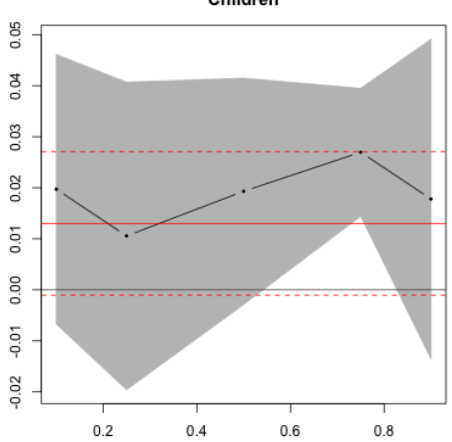

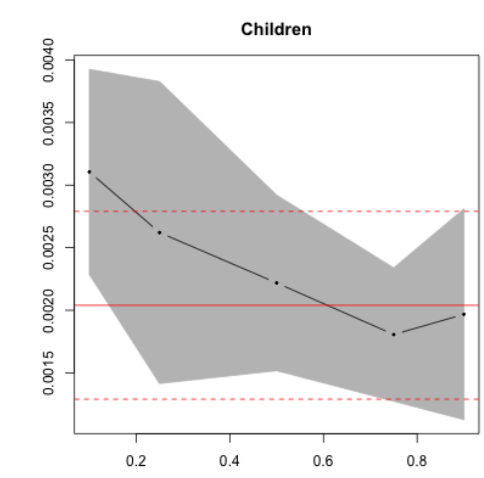

B2: Participation

Note: Black dots are the slope coefficients for the each estimated quantile. The solid red line is the least squares estimate, and red dashed line is its confidence interval. 
Figure 3.6: Quantile Regression Results using Predicted Values

Panel A: Unemployment Rate

A1: Number of Programs $\quad$ A2: Participation
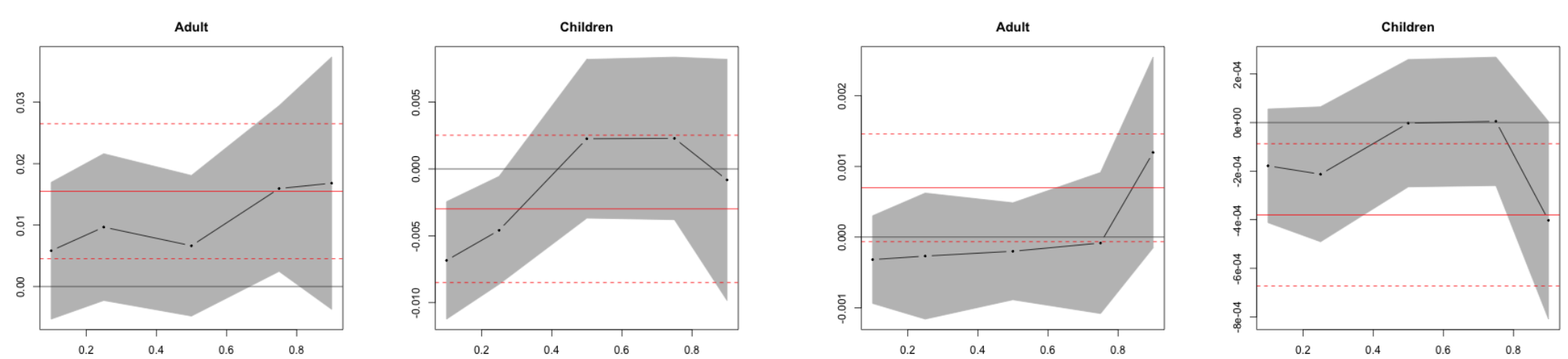

PanelPanel B: Labor Force Participation Rate

B1: Number of Programs
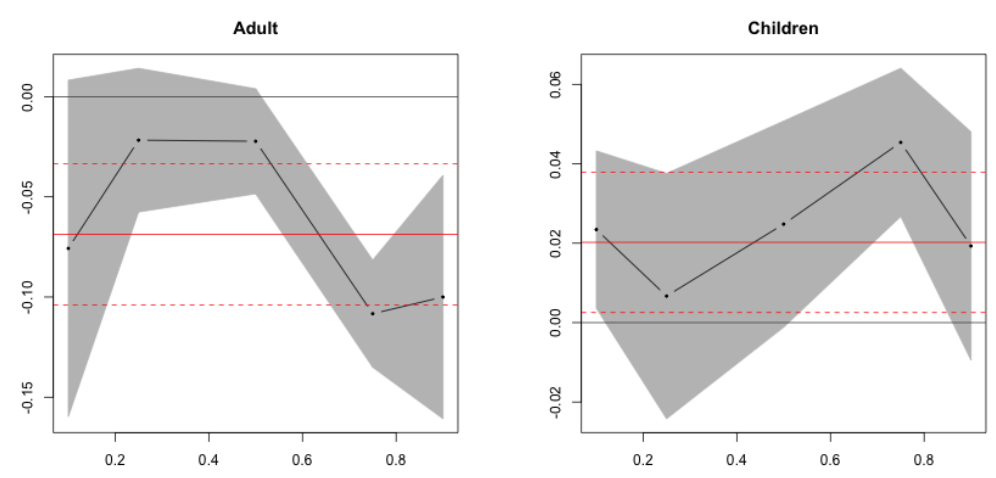

B2: Participation
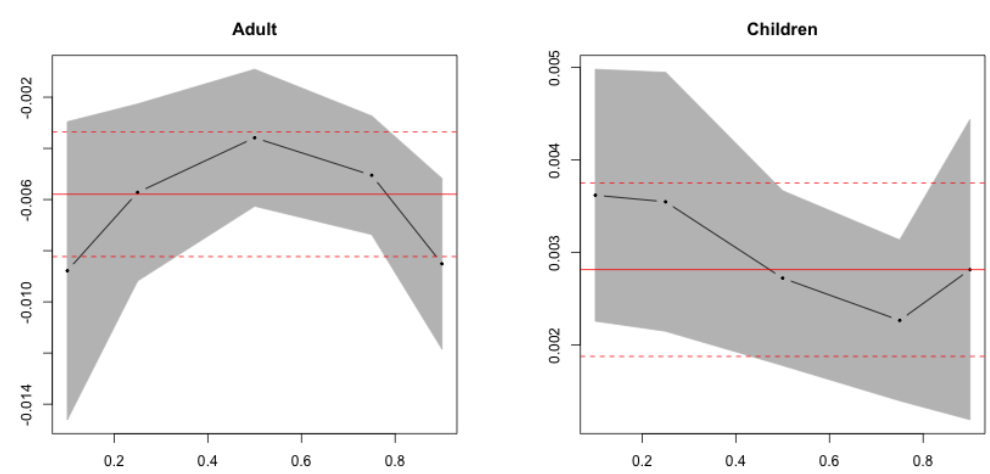

Note: Black dots are the slope coefficients for the each estimated quantile. The solid red line is the least squares estimate, and red dashed line is its confidence interval.
: 


\section{Chapter 4}

\section{Economies of Scale and Governance of Library Systems: Evidence from West Virginia}

\subsection{Introduction}

Education is an important part of publicly-provided services in both urban and rural areas, and public libraries can be a large part of community and K-12 education (Collins and Halverson, 2010). For example, in an important recent paper, Bhatt (2010) finds that library attendance of school children increases their time spent reading at home and positively impacts their homework completion rate. In addition, urban and rural communities value libraries in ways that are not captured in usage statistics as evidenced by contingent valuation studies (Aabø, 2005; Aabø and Strand, 2004; McCallum and Quinn, 2004).

The American Library Association (2015) estimates that there are over nine thousand public libraries in the United States, representing nearly $8 \%$ of the total number of libraries in the country. According to the Institute of Museums and Library Services (IMLS, 2014b) there were over 1.5 billion in-person visits to public libraries in 2012 alone. The IMLS (2015) reported that in 2012 public libraries had revenues of $\$ 11.5$ billion, $84.4 \%$ from local government sources, $6.9 \%$ from state sources, and less than $1 \%$ from the federal government. Across states, however, there is considerable variation. In West Virginia, for example, the 
state average local operating revenue per capita was $\$ 13.04$ compared to a national average of $\$ 32.31$ in the 2012 fiscal year.

The benefits of public libraries do come with costs, however, and Aabø and Strand (2004) highlights the recent pressures on public library budgets given other demands such as health care. As reported by Aabø and Strand (2004) and several others, local governments have been cutting public library funding, resulting in library branch closures and/or reduced hours. ${ }^{1}$ In response, some localities have passed special local levies to provide more funding to public libraries to restore cut or reduced services. West Virginia is an interesting case as 11 counties have special laws to fund public libraries. Since 2014 there have been at least two new levies placed on the ballot that have passed. ${ }^{2}$

We have three primary aims in this chapter. The first is to evaluate the efficiency of West Virginia public library systems. Given ongoing strains in public budgets in West Virginia (and other states), it is important to know whether public funds are being used efficiently. Second, after finding variation in technical efficiency (TE) across public library districts, we use our measures of TE to test whether the source of funding matters for efficiency. Hoxby (1999) provides reasons why local property tax-based finance can improve the productivity of local public good producers. Hall (2007) finds that Ohio school districts with a greater share of funding from local sources have higher scores on state exams. Additionally, people are concerned with the size of government and if their tax money is being allocated properly. Similar looks at the sources of public sector efficiency include Afonso et al. (2005), Smith and Street (2005), Afonso and Aubyn (2005), Afonso and Fernandes (2006), Detotto and McCannon (2017), and Zhu and Peyrache (2017). Lastly, we explore how county characteristics affect the technical efficiency.

Library funding comes from four different sources: local, state, and federal government, or non-public sources of funding. In West Virginia, local funding comes from direct appropriation, excess levies, or special laws; these can come from different local authorities like the Board of Education, County Commission and Municipal Funding, which have different

\footnotetext{
${ }^{1}$ Blau (2011), Warburton (2013), Smith (2015), Kelley (2015), Davis (2015), Stepleton (2015), Woods (2015) and Cleaver (2015) are non exhaustive examples.

${ }^{2}$ Willes (2016) and WV Gazette (2016).
} 
budges and responsibilities. State funding is a direct assistance on a per-capita basis and require matching funds from local authorities. Federal funding are available, but is dependent on each library to secure it. The non-public sources include fees, donations/fundraising, and grants (West Virginia Library Commission, 2013).

In looking at the technical efficiency of libraries we follow in the footsteps of a number of papers, each focusing on a different region. For example, Worthington (1999) assesses the efficiency of local government libraries in Australia, Hammond $(2002,2009)$ analyzes libraries in the of United Kingdom, and Witte and Geys (2011) studied all municipal public libraries in Flanders, Belgium. In United States, there are a handful of papers (Vitaliano, 1997, 1998; Sharma et al., 1999; Hemmeter, 2006). Vitaliano (1997) looks at the state of New York state using a stochastic frontier model and finds that public libraries are 3\% more inefficient than not-for-profit libraries. Vitaliano (1998) uses Data Envelopment Analysis (DEA) on 184 libraries - also in New York - and finds that libraries could reduce their inputs by one-third without compromising output. Sharma et al. (1999) evaluates 47 libraries in Hawaii for one fiscal year using DEA and find that the average technical efficiency is 0.84 with a range of 0.45 to 1 . As for Hemmeter (2006), the author analyzes the cost-efficiency of nearly all public libraries in the United States using a stochastic cost frontier and finds that inefficiency in smaller libraries is decreased with local government spending. ${ }^{3}$

We follow Vitaliano (1998) and Hammond (2002) and estimate the technical efficiency of public libraries in West Virginia using Data Envelopment Analysis (DEA). After estimating the technical efficiency of West Virginia libraries, we look at the institutional determinants of library efficiency in the state. Our results show that for West Virginia, local (that is, noncounty or multi-jurisdictional) libraries have lower levels of technical efficiency, suggesting an inability to take advantage of economies-of-scale. We also find a negative relationship between local support and technical efficiency, contrary to what the work of Hoxby (1999) and Hall (2007) suggest would be the case. These results are robust across different specifications and are important to voters, policymakers, and scholars of government efficiency.

\footnotetext{
${ }^{3}$ One reason to look within states, like we do with West Virginia, is that technical efficiency is a relative measure and the institutional constraints and funding methods vary so much across political jurisdictions that comparing Hawaii to West Virginia can be problematic.
} 
Amir B. Ferreira Neto

\subsection{Empirical Strategy}

\subsubsection{The Public Library Survey}

To analyze the efficiency of public libraries and revenues from government, we use the Public Libraries Survey (PLS). This dataset is collected annually since 1988 and covers all 50 states, the District of Columbia and outlying territories. The survey has a 98\% response rate and is the closest thing to a complete census of public library systems in the United States (IMLS 2014b). The PLS survey provides information for each library system on features such as location, attendance, staffing, revenues by source, salaries paid, collection expenditures, collection, circulation, etc.

We employ a balanced panel of libraries from 2009 to 2015 for the state of West Virginia $(\mathrm{WV})$. We chose this period of time because of data consistency with respect to the inputs and outputs used to estimate library technical efficiency (TE), as well as available demographic information. Table 4.1 presents some descriptive statistics of public library systems used throughout our analysis by governance. This is a first step to notice differences between libraries.

\subsubsection{Measuring Technical Efficiency}

The technical efficiency of a library is calculated using DEA. According to Bogetoft and Otto (2010), DEA analysis deals with two problems: estimating the standard and evaluating achievements against such determined standard. In this study we assume the Farrel notion of efficiency. Farrel efficiency is measured by minimizing inputs to reach the same level of output. Or conversely, by maximizing output given the current levels of inputs. The basic assumptions in the model are: free disposal, convexity and some determined return of scale.

Following Bogetoft and Otto (2010), define $x^{k}$ as the vector of $m$ inputs used and $y^{k}$ the $n$ outputs produced by firm $k$. TE can be calculated as:

$$
\begin{gathered}
T E_{k}=\min _{E, \lambda^{1}, \ldots, \lambda^{K}} E \\
\text { subject to: } \\
E x_{i}^{o} \geq \sum_{k=1}^{K} \lambda^{k} x_{i}^{k}, \quad i=1, \ldots, m
\end{gathered}
$$


Amir B. Ferreira Neto

$$
\begin{array}{r}
y^{o} \leq \sum_{k=1}^{K} \lambda^{k} y_{j}^{k}, \quad j=1, \ldots, n \\
\lambda \in \Lambda^{K}(\gamma) \quad(i i i)
\end{array}
$$

where $o$ refers to the standard firm, $\lambda$ is the parameter set, and $\gamma$ is an indicator of the return of scale. For more details, refer to Bogetoft and Otto (2010).

Note that the DEA is a non-parametric technique, thus, there is no requirement of assuming a specific production function. Moreover, by changing constraint (iii) it is possible to test whether the firm is operating in a decreasing or increasing return to scale area. By solving the system above for each firm, we obtain a number that reflects, geometrically, the distance of each firm to the production frontier. Hence, the values of each TE measure will be bounded between zero and one, and are relative measures of efficiency. The higher the $\mathrm{TE}$, the closer the firm is from the production possibility frontier and thus more efficient. To calculate TE, we use the package "Benchmarking" in R described by Bogetoft and Otto (2010).

We employ a variable returns to scale set-up. ${ }^{4}$ We use as inputs books, computers, librarians and total operational expenditure. Our measures of library output are the number of patron visits, hours opened, circulation, and number of programs provided to the community. ${ }^{5}$ Instead of estimating the level of efficiency over the entire panel, we calculate TE for each year. This also allows us to measure and control for changes in efficiency of each library across time. Table 4.2 has the inputs and outputs used to estimate the TE of each library through DEA. Panel A show the inputs and Panel B the outputs. Both take into account the population served by the library, which allows for us to control for density and possible congestion in use.

The DEA literature (Worthington, 1999; Hammond, 2002; Cooper et al., 2007) usually uses population as a non-discretionary input. Non-discretionary variables are those that are not under the control of managers, in this case, library officials. However, since we are

\footnotetext{
${ }^{4}$ We also calculate the TE using a constant return to scale assumption, and use it to identify the libraries operating under increasing returns to scale and the scale efficiency. It is interesting that no library operates under decreasing returns to scale.

${ }^{5}$ Library programs are services provided to its patrons. For instance, children's programs usually focus on education-related programs such as reading groups and activities or science programs, and entertainment programs like crafting and gaming programs. Adult programs, on the other hand, often focus on book activities, development of skills such as coding, and job search services. For more detail on these programs visit http://www.ala.org/alsc/kickstart and http://www.ala.org/tools/atoz/adultservices/adult_lib_svcs.
} 
looking at the public library system and not each branch, we encounter the Modifiable Areal Unit Problem (MAUP) (Arbia, 1988; Briant et al., 2010). The MAUP refers to a bias in statistical analysis from changes in the scale of observation (branches vs. library systems) or in the aggregation of data (city vs. county). In addition, the public library systems boundaries in WV are not fixed over time which impacts the population and area served, reinforcing the MAUP. One possible solution is the use of scaled measures which takes into account the areal issue, such as the one used in this chapter.

\subsubsection{Technical Efficiency Results for West Virginia Libraries}

Table 4.3 presents summary statistics for our TE results. Panel A has the overall results, Panel B focuses on the legal basis of the library, i.e., the governance of the library, and Panel C summarizes it by year. WV has three general types of governing authorities for libraries: city $(\mathrm{CI})$, county $(\mathrm{CO})$, and multi-jurisdictional $(\mathrm{MJ})$. WV code requires public libraries that receive state aid to be governed by a local authority such as a city, county, county board of education, or a combination of jurisdictions. ${ }^{6}$ By looking at these results, it is possible to have an idea of which type of public libraries are the most efficient and how efficiency changes over time.

In Table 4.3 we can see in Panel B that library systems controlled by more than one governing body are relatively more efficient than those managed by a single one. Libraries governed by county officials are relatively more efficient than those run by cities. Panel C shows that TE decreased from 2009-2012 period to 2013-2015 period, however, the TE is less spread in the latter. Appendix 1 shows the average TE and governance type for each library in the state of West Virginia over our sample.

To better understand the source of efficiency of West Virginia libraries, a first step is to look at the scale efficiency (SE). The scale efficiency is defined as the ratio between the technical efficiency under constant returns to scale to the technical efficiency under variable returns to scale. The $\mathrm{SE}$ is a measure of closeness to optimal scale size (Bogetoft and

\footnotetext{
${ }^{6}$ West Virginia Library Commission (2013) lists seven different types of public library governing authorities. We count anything that is not a county commission or a municipality as multi-jurisdictional. For example, the six joint County/Municipality library systems are counted as multi-jurisdictional, as are the nine Board of Education/County/Municipality governed library systems.
} 
Otto, 2010). Figure 4.1 shows the scale efficiency calculated for each public library system using the average TE under CRS and VRS plotted against the four inputs used in the analysis. The figures shows that the public libraries closest to its optimal scale are the MJ libraries. Although, the largest share of CO libraries have high SE (above 0.8), they also have the libraries with the lowest SE. On the other hand, CI libraries have more dispersed SE. Comparing the inputs, number of librarians and computers seems to be source of inefficiency.

\subsection{Explaining Technical Efficiency}

Allocative efficiency is an important topic in the public finance literature and for policymakers and citizens given current budget constraints. The case of public libraries in West Virginia is of special interest. State and local governments have been facing severe fiscal problems as the coal industry, the main driver of local government revenues, has declined over the past decade. The state also allows library to receive funds from local governments through special laws that in some cases date back to the 1930s. Moreover, special library levies have been placed onto local ballots in recent years and passed, suggesting the median voter in some communities desire more library output. In order to better understand the institutional determinants of TE in $\mathrm{WV}$, we regress the technical efficiency on the revenue from different sources and the legal base of the library system. Formally we have:

$$
T E_{i c t}=\alpha \operatorname{Rev}_{i c t}+\beta \operatorname{Gov}_{i t}+\gamma X_{i c t}+\mu_{c}+\delta_{t}+\epsilon_{i c t}
$$

where $T E_{i c t}$ is the technical efficiency of library system $i$, in county $c$, in year $t$; Rev is the vector of revenue from local, state and federal governments, Gov is the vector of dummy variables for governance of each library system, $X$ is a vector of control variables such as existence of branches, if the library is operating under increasing returns to scale, unemployment rate, personal income per capita, high-school graduation rate, and demographic controls such as gender, race and age; $\mu_{c}$ is county fixed effect, and $\delta_{t}$ year fixed effect.

Our primary variables of interests are those related to governance structure and the source of funding. Following Hoxby (1999) and Hall (2007) we expect local spending to be positively related to TE. We do not have strong priors with respect to governance structure, although 
the work of Ostrom et al. (1961) suggests that cities and multi-jurisdictional governments might be more efficient as they might be more "organic" than county governance. We also include a binary variable for whether or not the library district had a special law passed by the state legislature that gives it dedicated local funding from the property tax. ${ }^{7}$ Table 4.4 provides summary statistics of the control variables used in the econometric analysis.

As previously discussed, we are interested in three set of results. Primarily, we want to know if public libraries governed by local authorities are relatively more efficient than others. Then we want to test if governments are investing in efficient libraries, which in turn suggests that they favor voters and their demand for more types of public goods. Lastly, we want to know which county characteristics influence the technical efficiency of public libraries.

Our baseline empirical results are presented in Table 4.5. Column 1 has the results estimated using Ordinary Least Squares (OLS) with no year and county fixed effects. Columns 2 and 3 include year, and year and county fixed effects respectively. Column 4 and 5 estimate the model using Weighted Least Squares (WLS) with personal income per capita used as the weight. The WLS estimates also include either year or county and year fixed effects. Demographic control variables are included, but we only report those statistically significant. County governments are the excluded type of jurisdiction, thus city and multi-jurisdictional should be interpreted as in reference to county libraries. For demographic controls we exclude population with less than 15 years-old and percent of white population. Standard-errors are clustered by county.

Looking at our results, the first thing that is apparent is that the source of public funding, i.e. local, state or federal, is not correlated to the level of technical efficiency. The exception is a positive and statistically significant correlation for state funding when controlling for time and county fixed effects. Turning to our governance variables, we find across all five specifications that compared to library systems that are governed by county governments, city governance is negatively related to TE. Depending on the specification, a city governed

\footnotetext{
${ }^{7}$ Special laws are laws initiated locally and passed by the Legislature. These laws set aside part of the tax dollars from local government (Board of Education, County or City) to public libraries. Some of special laws have been in place since 1930s and the most recent is from 1994. However, since 2013 it is no longer a mandatory that Board of Educations to continue providing funding to public libraries. For more on these special laws, see West Virginia Library Commission (2013).
} 
library is between 5 to 11 percentage points less technically efficient, ceteris paribus. We find no statistically significant results for multi-jurisdictional libraries. In addition, libraries operating under increasing returns to scale are on average 16 percentage points less technically efficient than those which are not. This result is consistent across the different specifications.

Finally, we focus on demographic characteristics. In terms of high-school graduation rate, public libraries in counties with higher graduation rates are associated with lower technical efficient. However, when controlling for county unobserved characteristics these results are not different from zero. In addition, after controlling for county and year fixed effects, the results imply that libraries in counties with higher multi-racial population are also technically less efficient, while those with higher population between 45-64 years old are technically more efficient.

One concern about our results in Table 4.5 is that our dependent variable is bounded between 0 and 1 and therefore the normality assumption of OLS is not valid. To deal with this issue we employ the fractional logit method with and without county and year fixed effects. These results are presented in Table 4.6. Both columns show the same specifications as in Table 4.5, with Column 1 excluding county and year fixed effects and Column 2 including year fixed effects, and Columns both year and county fixed effects. The results corroborate our previous analysis showing a negative and statistically significant relationship between technical efficiency and city governance. The results for increasing returns to scale libraries, libraries in larger multi-racial counties, and with larger population within 45-64 year-old are also maintained.

Unlike in our OLS and WLS regressions, however, we find a negative association between technical efficiency and local funding, and positive association with state funding. Our empirical approach does not allow us to speak to causality on the funding source/technical efficiency relationship. It could be that having larger share of the budget from state government lead to public libraries being more technically efficient. We cannot, however, rule out reverse causality. Our results could reflect that more technically efficient libraries are more likely to receive state funding, especially in light of matching requirements from local funding. Similarly we cannot rule out that technically inefficient public libraries are more likely to garner higher levels of local financial support vis-a-vis the receiving larger share 
from local governments leading to more inefficiency.

Additionally, having branches is associated with larger technical efficiency, as well as larger black population. However, latin population and population between 15 and 24 yearsold are associated with lower technical efficiency. These results, however, are not statistically different from zero when controlling for county fixed effects.

\subsection{Discussion and Implications}

The objectives of this chapter were to evaluate public library efficiency in West Virginia and to investigate whether there was a relationship between government funding and technical efficiency. Using data from the Public Library Survey from 2009 to 2015, we calculated a technical efficiency measure using data envelopment analysis, and then regressed on data of government revenue for each library. Moreover, we were able to look at the role that the governing body of public libraries paid with respect to efficiency.

While not causal, the results suggest that libraries governed by cities are less efficient than those governed by counties or multiple jurisdictions. This may be because city library systems are too small to achieve the economies-of-scale exhibited by the county and multijurisdictional libraries. ${ }^{8}$ The relative efficiency of county systems is interesting in light of the work of Fischel (2007), who argues there may be gains when school districts and library systems are congruent, as synchronization of programs would be easier. In West Virginia, all school districts are county districts. One reason for county libraries as being more efficient might be greater synchronization with county school districts. Further research is clearly needed on this point as well as trying to tease out the causal direction of these associations.

Finally, our results with respect to local funding were the opposite of what was predicted by the literature on the efficiency of local public good provision. While we do not find strongly consistent evidence, it does not appear that libraries where more funding comes from local sources are more technically efficient. Given the increasing use of local levies to fund libraries in West Virginia, this finding has important public policy implications for

\footnotetext{
${ }^{8}$ All city libraries are, by definition, smaller in area - but maybe not population - than county or multijurisdictional libraries.
} 
library funding in the state moving forward. 
Table 4.1: Descriptive Statistics by Governance

\begin{tabular}{|c|c|c|c|c|c|c|c|}
\hline \multirow[t]{2}{*}{ Statistic } & \multirow[t]{2}{*}{ Description } & \multicolumn{2}{|c|}{ City } & \multicolumn{2}{|c|}{ County } & \multicolumn{2}{|c|}{$\begin{array}{l}\text { Multi- } \\
\text { Jurisdictional }\end{array}$} \\
\hline & & Mean & $\mathrm{SD}$ & Mean & $\mathrm{SD}$ & Mean & $\mathrm{SD}$ \\
\hline Population & Population served by library & 11,960 & 17,904 & 22,414 & 30,953 & 31,539 & 29,373 \\
\hline Librarians & Number of full-time librarians & 2.44 & 3.81 & 3.76 & 4.23 & 7.01 & 12.29 \\
\hline Books & Number of print materials & 37,412 & 41,705 & 60,802 & 85,913 & 83,204 & 107,420 \\
\hline Hours & Total annual public service hours & 2,733 & 1,894 & 4,874 & 4,358 & 5,585 & 4,861 \\
\hline Visits & Total annual visits & 36,936 & 55,533 & 67,027 & 136,097 & 108,092 & 122,456 \\
\hline Circulation & Total annual circulation & 44,548 & 65,036 & 82,395 & 164,778 & 124,789 & 165,388 \\
\hline Computers & Internet computers for general public & 10 & 9 & 19 & 27 & 18 & 17 \\
\hline Programs & Total library programs & 162 & 264 & 290 & 576 & 291 & 449 \\
\hline Branch & Share of libraries with a branch & 0.08 & 0.28 & 0.47 & 0.50 & 0.45 & 0.50 \\
\hline Local & Local government revenue $(\$)$ & 116,276 & 250,774 & 319,128 & $1,025,807$ & 424,893 & 647,748 \\
\hline State & State Government Revenue (\$) & 58,197 & 92,258 & 101,539 & 141,915 & 162,962 & 171,460 \\
\hline Federal & Federal Government Revenue $(\$)$ & 1,611 & 8,536 & 1,347 & 7,756 & 11,623 & 31,178 \\
\hline Other & Donations, fees and grants $(\$)$ & 20,458 & 25,945 & 33,433 & 67,463 & 42,295 & 51,928 \\
\hline Expenditure & Total operational expenditures $(\$)$ & 185,566 & 328,386 & 409,508 & $1,073,498$ & 582,006 & 788,330 \\
\hline
\end{tabular}

$\mathrm{N}:$ City $=336$, County $=224$, Multi-Jurisdictional $=119$. Operational expenditure includes: staff, collection and other expenditure. Print materials include: books, serial back files, and government documents. Total Programs include all adult and children programs offered by the library. Hours include the hours of public service from all branches and bookmobiles. 
Table 4.2: Inputs and Outputs for DEA

\begin{tabular}{lcccc}
\hline \hline Statistic & Mean & St. Dev. & Min & Max \\
\hline Panel A: Inputs & & & & \\
\hline Books per 1,000 people & 3,658 & 3,082 & 674 & 26,062 \\
Computers per 1,000 people & 1.228 & 1.578 & 0.175 & 20.161 \\
Librarian per 1,000 people & 0.246 & 0.210 & 0.040 & 1.606 \\
Expenditure per 1,000 people & 15,198 & 11,828 & 4,226 & 89,021 \\
& & & & \\
Panel B: Outputs & & & & \\
Hours per total year-hour & 0.450 & 0.421 & 0.148 & 2.558 \\
Visits per 1,000 people & 3,215 & 2,397 & 628 & 17,218 \\
Circulation per 1,000 people & 3,677 & 3,475 & 43 & 32,198 \\
Programs per 1,000 people & 16.824 & 32.681 & 0.262 & 486.081 \\
\hline \hline
\end{tabular}

$\mathrm{N}: 679$. 
Table 4.3: Descriptive Statistics for Technical Efficiency

\begin{tabular}{|c|c|c|c|c|c|}
\hline State & $\mathrm{N}$ & Mean & St. Dev. & Min & Max \\
\hline \multicolumn{6}{|c|}{ Panel A: Overall } \\
\hline $\mathrm{TE}$ & 679 & 0.860 & 0.166 & 0.297 & 1.000 \\
\hline \multicolumn{6}{|c|}{ Panel B: By Governance } \\
\hline $\mathrm{CI}$ & 336 & 0.83 & 0.18 & 0.30 & 1.00 \\
\hline $\mathrm{CO}$ & 224 & 0.88 & 0.16 & 0.44 & 1.00 \\
\hline MJ & 119 & 0.90 & 0.13 & 0.56 & 1.00 \\
\hline \multicolumn{6}{|c|}{ Panel C: By Year } \\
\hline 2009 & 97 & 0.86 & 0.17 & 0.37 & 1.00 \\
\hline 2010 & 97 & 0.87 & 0.18 & 0.30 & 1.00 \\
\hline 2011 & 97 & 0.86 & 0.17 & 0.35 & 1.00 \\
\hline 2012 & 97 & 0.87 & 0.15 & 0.47 & 1.00 \\
\hline 2013 & 97 & 0.85 & 0.16 & 0.35 & 1.00 \\
\hline 2014 & 97 & 0.86 & 0.16 & 0.33 & 1.00 \\
\hline 2015 & 97 & 0.85 & 0.17 & 0.34 & 1.00 \\
\hline
\end{tabular}


Amir B. Ferreira Neto

Chapter 4. Technical Efficiency of Library Systems

Table 4.4: Control Variables

\begin{tabular}{|c|c|c|c|c|c|}
\hline Statistic & Description & Mean & St. Dev. & Min & Max \\
\hline \multicolumn{6}{|c|}{ Panel A: County Demographic Characteristics } \\
\hline Female & Percent of female population & 0.504 & 0.016 & 0.395 & 0.560 \\
\hline Asian & Percent of Asian population & 0.004 & 0.004 & 0.0001 & 0.033 \\
\hline Black & Percent of Black population & 0.023 & 0.025 & 0.0001 & 0.128 \\
\hline Other Race & Percent of Other Race population & 0.001 & 0.002 & 0.000 & 0.026 \\
\hline Two Plus & Percent of Two or More Races population & 0.012 & 0.004 & 0.005 & 0.027 \\
\hline AmerIndian & Percent of American Indian population & 0.002 & 0.001 & 0.001 & 0.009 \\
\hline Latin & Percent of Latin population & 0.011 & 0.010 & 0.003 & 0.062 \\
\hline White & Percent of White population & 0.958 & 0.031 & 0.825 & 0.990 \\
\hline Pop 15L & Percent of population with less than $15 y 0$ & 0.169 & 0.013 & 0.112 & 0.210 \\
\hline Pop 15-24 & Percent of population between $15 y o$ and 24 yo & 0.118 & 0.021 & 0.093 & 0.301 \\
\hline Pop 25-44 & Percent of population between $25 y o$ and $44 y$ & 0.237 & 0.018 & 0.187 & 0.320 \\
\hline Pop 45-64 & Percent of population between $45 y o$ and $64 y$ & 0.296 & 0.016 & 0.213 & 0.339 \\
\hline Pop 65P & Percent of population with more than $65 y 0$ & 0.180 & 0.024 & 0.102 & 0.258 \\
\hline Personal Income & Personal Income per capita in real terms & 30.166 & 4.447 & 16.665 & 44.285 \\
\hline Graduation & 4-year High-School Graduation Rate & 0.817 & 0.066 & 0.660 & 0.970 \\
\hline Unemploy & Unemployment rate & 8.391 & 1.944 & 4.117 & 14.149 \\
\hline \multicolumn{6}{|c|}{$\underline{\text { Panel B: Library Characteristics }}$} \\
\hline Special Law & Dummy for library with special law & 0.165 & 0.371 & 0.000 & 1.000 \\
\hline IRS & Dummy for library under increasing returns to scale & 0.716 & 0.451 & 0.000 & 1.000 \\
\hline CI Gov. & Dummy for library with city governance & 0.495 & 0.500 & 0.000 & 1.000 \\
\hline CO Gov. & Dummy for library with county governance & 0.330 & 0.471 & 0.000 & 1.000 \\
\hline MJ Gov. & Dummy for library with Multi-Jurisdictional governance & 0.175 & 0.380 & 0.000 & 1.000 \\
\hline Local \% & Percent Revenue from Local Government & 0.488 & 0.181 & 0.038 & 0.904 \\
\hline State $\%$ & Percent Revenue from State Government & 0.372 & 0.136 & 0.049 & 0.837 \\
\hline Federal \% & Percent Revenue from Federal Government & 0.006 & 0.033 & 0.000 & 0.383 \\
\hline Other \% & Percent Revenue from other sources & 0.134 & 0.105 & 0.000 & 0.538 \\
\hline
\end{tabular}

$\mathrm{N}=679$. Special Laws are laws initiated locally and passed by the Legislature. These laws set aside part of local government tax dollars for the operation of the public library. 
Table 4.5: Least Square Results

\begin{tabular}{|c|c|c|c|c|c|}
\hline & \multicolumn{5}{|c|}{ Dependent variable: Technical Efficiency } \\
\hline & \multirow[t]{2}{*}{ OLS } & \multicolumn{2}{|c|}{$\mathrm{FE}$} & \multicolumn{2}{|c|}{ WLS } \\
\hline & & $(1)$ & $(2)$ & $(1)$ & $(2)$ \\
\hline \multirow[t]{2}{*}{ Local \% } & -0.142 & -0.159 & -0.114 & -0.153 & -0.123 \\
\hline & $(0.104)$ & $(0.106)$ & $(0.080)$ & $(0.101)$ & $(0.077)$ \\
\hline \multirow[t]{2}{*}{ State $\%$} & 0.184 & 0.176 & $0.238^{*}$ & 0.147 & 0.231 \\
\hline & $(0.112)$ & $(0.116)$ & $(0.133)$ & $(0.121)$ & $(0.146)$ \\
\hline \multirow[t]{2}{*}{ Federal \% } & 0.128 & 0.148 & 0.167 & 0.170 & 0.179 \\
\hline & $(0.113)$ & $(0.115)$ & $(0.115)$ & $(0.128)$ & $(0.123)$ \\
\hline \multirow[t]{2}{*}{ CI Gov. } & $-0.050^{* *}$ & $-0.052^{* *}$ & $-0.108^{* * *}$ & $-0.061^{* * *}$ & $-0.113^{* * *}$ \\
\hline & $(0.024)$ & $(0.023)$ & $(0.041)$ & $(0.023)$ & $(0.042)$ \\
\hline \multirow[t]{2}{*}{ MJ Gov. } & 0.001 & 0.0004 & -0.041 & -0.001 & -0.042 \\
\hline & $(0.023)$ & $(0.024)$ & $(0.043)$ & $(0.025)$ & $(0.043)$ \\
\hline \multirow[t]{2}{*}{ Branch } & 0.034 & 0.031 & -0.027 & 0.022 & -0.026 \\
\hline & $(0.035)$ & $(0.036)$ & $(0.063)$ & $(0.033)$ & $(0.063)$ \\
\hline \multirow[t]{2}{*}{ Special Law } & -0.012 & -0.009 & -0.113 & -0.010 & -0.122 \\
\hline & $(0.037)$ & $(0.037)$ & $(0.082)$ & $(0.037)$ & $(0.084)$ \\
\hline \multirow[t]{2}{*}{ IRS } & $-0.167^{* * *}$ & $-0.166^{* * *}$ & $-0.159^{* * *}$ & $-0.165^{* * *}$ & $-0.161^{* * *}$ \\
\hline & $(0.022)$ & $(0.022)$ & $(0.025)$ & $(0.023)$ & $(0.028)$ \\
\hline \multirow[t]{2}{*}{ Two Plus Race } & 4.395 & 0.671 & $-8.488^{* *}$ & 1.312 & $-9.411^{* *}$ \\
\hline & $(3.598)$ & $(4.561)$ & $(3.888)$ & $(4.496)$ & $(4.001)$ \\
\hline \multirow[t]{2}{*}{ Pop 45-64 } & $-2.362^{*}$ & -2.136 & $3.108^{* * *}$ & -2.118 & $2.894^{* * *}$ \\
\hline & $(1.285)$ & $(1.520)$ & $(1.105)$ & $(1.565)$ & $(1.109)$ \\
\hline \multirow[t]{2}{*}{ Graduation Rate } & $-0.297^{*}$ & $-0.404^{* *}$ & -0.006 & $-0.369^{* *}$ & -0.001 \\
\hline & $(0.155)$ & $(0.169)$ & $(0.117)$ & $(0.162)$ & $(0.123)$ \\
\hline $\mathrm{R}^{2}$ & 0.419 & 0.429 & 0.654 & 0.428 & 0.643 \\
\hline Year FE & & $\sqrt{ }$ & $\sqrt{ }$ & $\sqrt{ }$ & $\sqrt{ }$ \\
\hline County FE & & & $\sqrt{ }$ & & $\sqrt{ }$ \\
\hline
\end{tabular}

Clustered standard errors in parentheses. ${ }^{*} \mathrm{p}<0.1{ }^{* *} \mathrm{p}<0.05 ;{ }^{* * *} \mathrm{p}<0.01$. Note: $\mathrm{N}=679$ in all regressions. The following demographic control variables are included but are not statistically, thus are omitted: Unemploy, Personal Income, Female, Asian, Black, Latin, Other Race, AmerIndian, Pop 15-24, Pop 25-44, Pop 65P. Omitted dummy variables: Other \%, CO Gov., Pop 15L and White. 
Table 4.6: Fractional Logit Results

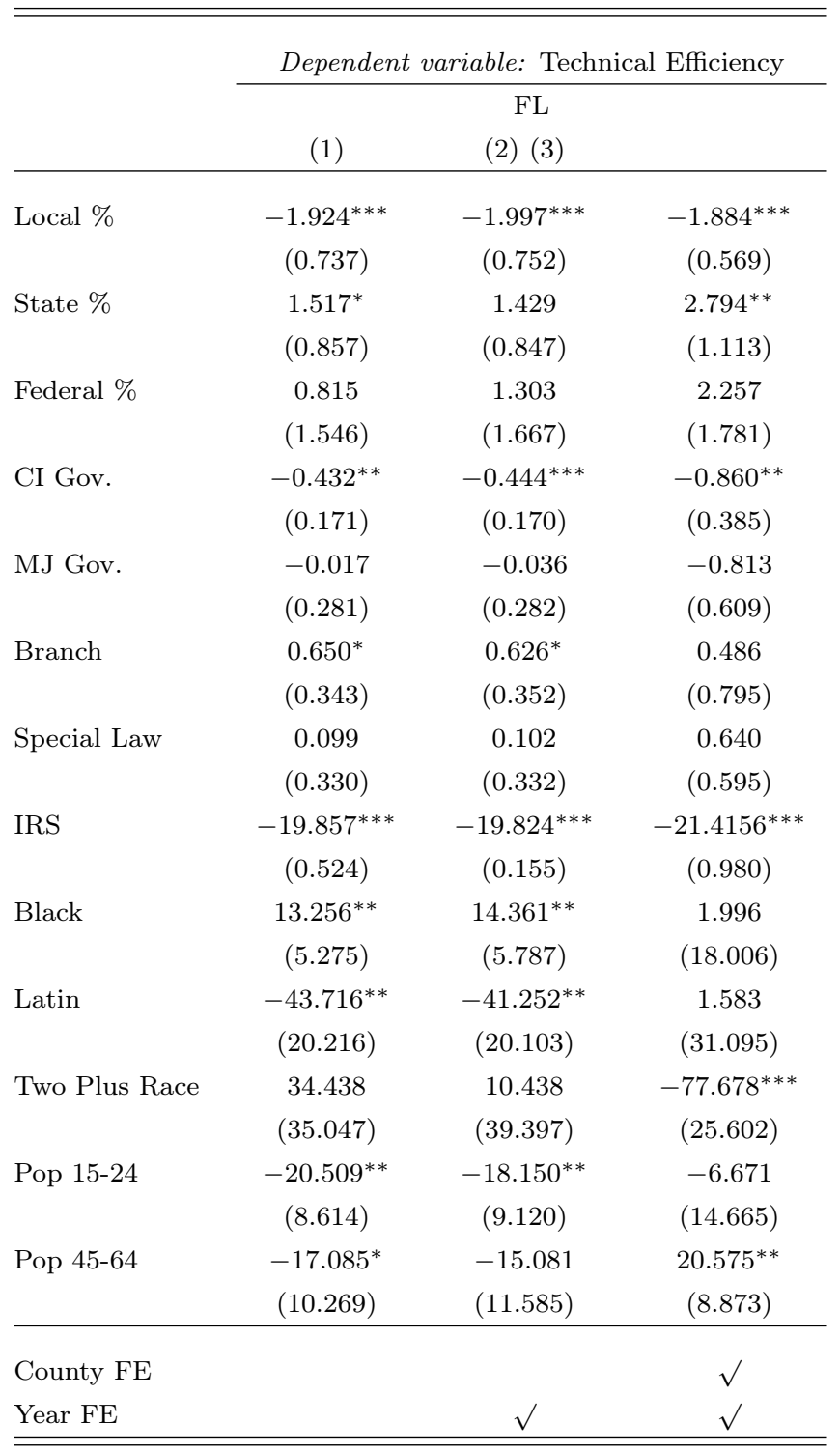

Clustered standard errors in parentheses. ${ }^{*} \mathrm{p}<0.1 ;{ }^{* *} \mathrm{p}<0.05$; ${ }^{* * *} \mathrm{p}<0.01$. Note: $\mathrm{N}=679$ in all regressions. The following demographic control variables are included but are not statistically, thus are omitted: Unemploy, Personal Income, Female, Asian, Other Race, AmerIndian, Pop 25-44, Pop 65P, Graduation Rate. Omitted dummy variables: Other \%, CO Gov., Pop 15L and White. 
Figure 4.1: Scale Efficiency by Inputs
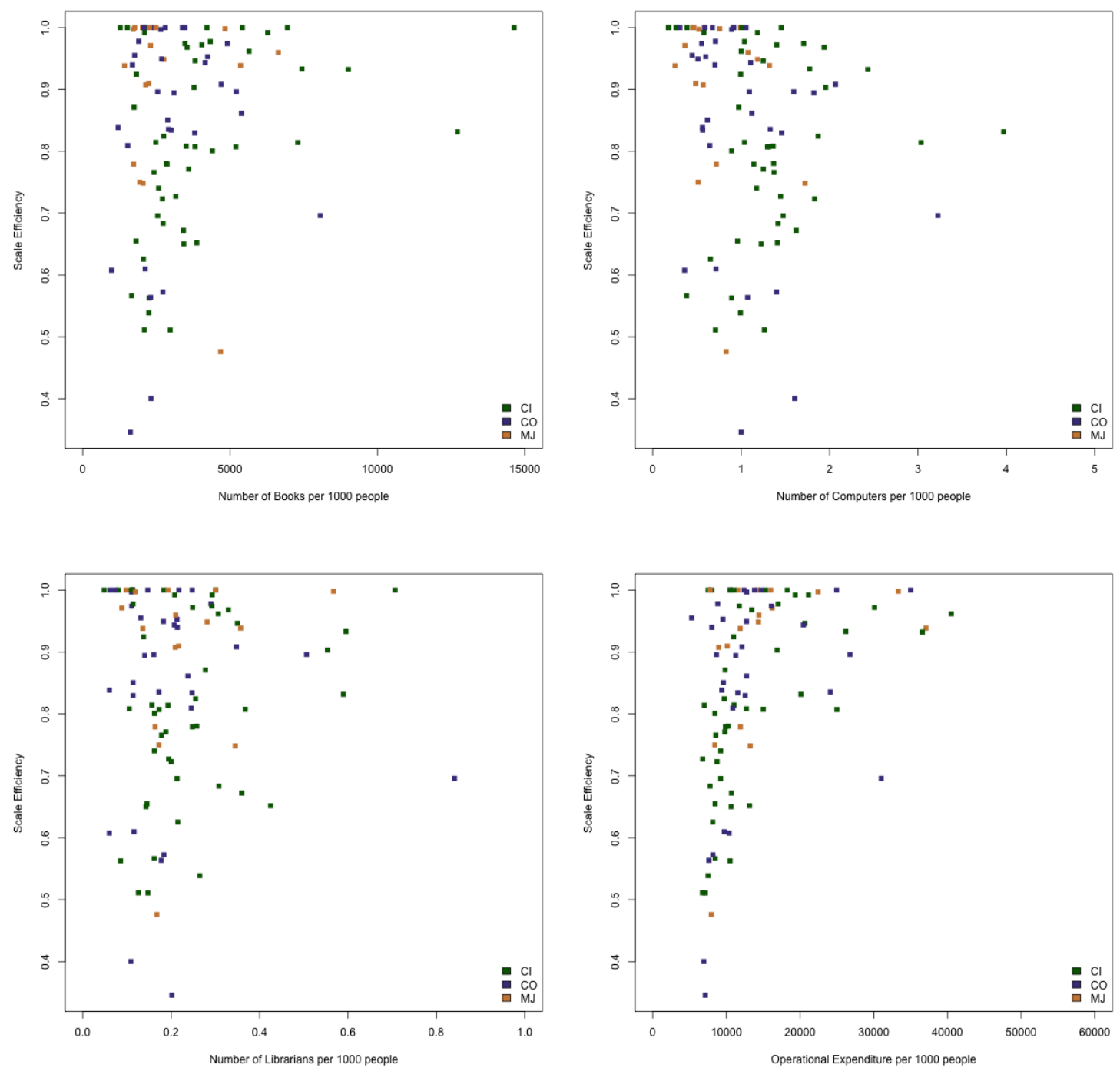


\section{Chapter 5}

\section{Concluding Remarks}

Public libraries are part of the American culture (Wiegand, 2015), however, they have not gained much attention from economists. This dissertation tries to bridge this gap and explore empirical issues concerning public libraries in the United States focusing on the direct and indirect effects to and from public libraries, on different issues: Chapter 2 focuses on private donations to public libraries in the country, Chapter 3 investigates the effect of public library programs and participation on unemployment and labor force participation in Appalachia, and Chapter 4 explores the institutional determinants of public library technical efficiency in West Virginia.

In Chapter 2, I find a positive correlation between donation and government spending in every level. This suggests possible crowd in effect, that is, every dollar spent by the government would bring some extra amount of money to the libraries from private donors. In particular, I find that local government would bring an extra 4-6 cents in donation, state government 20-23 cents and the federal government 73 cents to 1 dollar and 33 cents per dollar spent. In addition, I also find an inverted $U$ shape relation between government expenditure and donation.

Chapter 3 shows no evidence that public library programs and participation affect local labor market outcomes, at least in an aggregate level. These results are robust across different specifications and control groups. Spatial econometric estimates, however, show suggestive results that there is an indirect effect of public library programs and participation, specially for children's program. 
Chapter 4, in turn, reports technical efficiency measures for public library systems in West Virginia between 2009 to 2015. Then, it analyzes the effect of institutional characteristics, in particular governance and funding, and demographic characteristics, on the technical efficiency measures. The technical efficiency results show that public libraries systems in West Virginia are on average efficient, but there is some variation across time and systems. As for the econometrics results, local government support negatively impacts technical efficiency, and local library systems are less efficient than county and multi-jurisdictional systems. In addition, higher high-school graduation rates and multi-racial population are associated with lower public library technical efficiency while the opposite is true for older population (between 45 and 64 year-old).

There are several implications from the results presented above. First, the cuts on government budgets to public libraries could have a worse impact than those anticipated by policy-makers. Chapter 2 shows that there can be an indirect budget effect that could further decrease revenues due to the suggested crowd in effect. Chapter 3, on the other hand, provides evidence of spatial spillover, especially from children's program and participation.

Second, direct cuts make public libraries face a tighter budget. Hence, public libraries must be mindful of their budget allocation in order to be the most effective for their communities, as shown in Chapter, but also, remain efficient as discussed in Chapter 4. Lastly, there are public libraries in most counties in the country. These libraries influence their local communities, but are also influenced and constrained by institutions such as government, management, etc. as described in Chapter 4. Hence, whenever policy-makers are making decisions concerning these libraries it is important to take into account the whole set of information, as heterogenous results should be expected.

Future work should expand on these issues and concentrate in gathering more and better data on public library systems and its patrons. By doing so, it is possible to disentangle some of the mechanisms described in this dissertation that can affect and be affected by public libraries. Unfortunately, most of these issues were not pursued here due to data constraints and its aggregate nature. However, this work is another step into understanding and explaining the role public libraries play in local communities. 
Chapter 6

Appendices 
Amir B. Ferreira Neto

Chapter 6. Appendices

\subsection{Appendices to Chapter 2}

\subsubsection{Appendix Tables}

Table 6.1: Variables description

\begin{tabular}{|c|c|c|}
\hline Variable & Descriptive & Source \\
\hline Donation & Other Revenue Sources (donations, grants and fees) & Public Library Survey \\
\hline Local & Local Government Revenues & Public Library Survey \\
\hline Local2 & Local Government Revenues squared & Created from PLS \\
\hline State & State Government Revenues & Public Library Survey \\
\hline State2 & State Government Revenues squared & Created from PLS \\
\hline Federal & Federal Government Revenues & Public Library Survey \\
\hline Federal2 & Federal Government Revenues squared & Created from PLS \\
\hline Population & Population in & Public Library Survey \\
\hline Master & Employees with master degree & Public Library Survey \\
\hline Librarian & Librarian employees & Public Library Survey \\
\hline OtherPaid & Other paid employees & Public Library Survey \\
\hline HrsOpen & Number of hours the library was open & Public Library Survey \\
\hline Visits & Number of visits in the library & Public Library Survey \\
\hline KidAttendance & Number of attendance in children programs & Public Library Survey \\
\hline GPTerm & Number of general public terminals with internet connection & Public Library Survey \\
\hline BookVolume & Book volumes & Public Library Survey \\
\hline AudioCol & Audio collection & Public Library Survey \\
\hline VideoCol & Video collection & Public Library Survey \\
\hline Age & Average age in the state & IPUMS-CPS \\
\hline Pincome & Average personal income in state & IPUMS-CPS \\
\hline Female & Percentage of female in state & IPUMS-CPS \\
\hline White & Percentage of white people in state & IPUMS-CPS \\
\hline Black & Percentage of black people in state & IPUMS-CPS \\
\hline Married & Percentage of married couples in state & IPUMS-CPS \\
\hline Immigrant & Percentage of immigrants in state & IPUMS-CPS \\
\hline HighSchool & Percentage of people with high school degree in state & IPUMS-CPS \\
\hline College & Percentage of people with college degree & IPUMS-CPS \\
\hline Unemploy & Percentage of unemployed people & IPUMS-CPS \\
\hline SchDistrict & Dummy variable that equals to 1 if library is run by school district & Created from PLS \\
\hline NonProfit & Dummy variable that equals to 1 if library is run by non-profit & Created from PLS \\
\hline NewEngland & Dummy variable that equals to 1 if it is in New England & Created from PLS \\
\hline Mideast & Dummy variable that equals to 1 if it is in Mideast & Created from PLS \\
\hline GreatLakes & Dummy variable that equals to 1 if it is in Great Lakes & Created from PLS \\
\hline Kap & Dummy variable that equals to 1 if 1 & Created from PLS \\
\hline
\end{tabular}




\subsubsection{Instrumental Variable Approach}

One important discussion in the crowd-out literature is the ability to identify a causal relation between donations and government expenditures. Unfortunately, this is not possible with the Public Library Survey because donations from grants and fees are mixed. In this online appendix, I present robustness tests using instrumental variables to address endogeneity. I have three measures of government spending: local, state and federal. I therefore need a set of three instruments, one for each level of government, that are correlated to each level of government spending but exogenous from donations.

I perform two instrumental variables exercises, using different sets of instruments. At first, because I evaluate the current level of government spending with the current level of donations, I use lagged government expenditures as instruments for current expenditures. One can argue that lagged variables are good instruments because it is likely that there is a trend in government expenditures. People are also more interested in the current level of library revenues rather than revenues from previous years. This first exercise allows me to take advantage of the time-series nature of my data.

For the second instrumental variable exercise, I employ a set of variables that were not in my original dataset. The first variable in this set of instruments is the counts of FEMA (Federal Emergency Management Agency) claims per county in a given year. This is a good instrument because a natural disaster is exogenous from donations. Also, FEMA requires that a local government matches part of the amount requested for the agency. This makes local governments have a tighter budget to spend in other goods and services publicly provided. It is therefore correlated with government expenditures. The second instrumental variable is SNAP (Supplemental Nutrition Assistance Program) expenditures from each state in every year of analysis. Again, on one hand, governments face a trade-off between spending on libraries or other types of programs such as SNAP. Thus states with higher SNAP expenditures in a given year would have less available resources to spend in libraries in that same year. On the other hand, it is not likely that people will increase their donation to library or other public provided services in years that the government has to spend more with social programs such as SNAP. SNAP data comes from FRED (2016) at 
the St. Louis Federal Reserve.

Lastly, I use political information as an instrumental variable. I use a dummy variable that equals one if the majority of the state's lower house of have the same party as the President, and another dummy for the state's upper house with the same criterion. The intuition behind these variables is that, states with senate or house where the majority of representatives has the same party as the president, would have a stronger lobby to acquire more funds for their states to spend with public provided goods and services. However, having the majority of the state house/senate to be the same party as the president would not impact private donation decisions. Moreover, by using the majority in the state house I can have annual, or at least, bi-annual variation, which would not be possible if I used the party of governor versus the party of the president. This information was obtained from ballotpedia.org.

The results from both exercises are presented in tables A1 and A2, respectively. The results $1 \mathrm{~A}$ to $5 \mathrm{~A}$ refers to the lag instruments and $1 \mathrm{~B}$ to $3 \mathrm{~B}$ to the second set of instruments. The Tobit t-statistics and confidence intervals (Table A1) were obtained using the package "boot" in R, with 999 replications. At first we can notice that the F-test shows that the lag instruments are strong, but the second set of instruments have F-tests smaller than 10, but statistically significant. For the lagged variables results, overall there seems to be a crowdin effect with an inverted $U$ shape just as the main results reported in the paper. When controlling for library fixed effect (model 3A) there results suggest a crowd-out effect from state government expenditure. The results for the Tobit estimations (4A and $5 \mathrm{~A})$ points to a crowd-in effect and inverted U shape for all government levels.

For the second set of instruments, the results also suggest a crowd-in effect with an inverted $U$ shape. The models without library fixed effect (1B and $2 \mathrm{~B}$ ) point to a crowdout effect from state government expenditure. Because the instruments are weak, I do not present the Tobit estimations. However, these results seem to be in line with the ones in the manuscript. Therefore, although I cannot claim a causal effect between donations and government expenditures, the results presented in this online appendix corroborate the results from the paper suggesting there is a positive correlation between these variables. 
Table 6.2: Results

\begin{tabular}{|c|c|c|c|c|}
\hline & \multicolumn{4}{|c|}{ Dependent variable: Donation } \\
\hline & $(1 \mathrm{~A})$ & $(2 \mathrm{~A})$ & $(3 \mathrm{~A})$ & $(4 \mathrm{~A})$ \\
\hline \multirow[t]{2}{*}{ Locr-hat } & $0.057^{* * *}$ & $0.021^{* * *}$ & $0.001^{* *}$ & $0.001^{* *}$ \\
\hline & $(0.0005)$ & $(0.003)$ & $(1.010)$ & $(2.037)$ \\
\hline \multirow[t]{2}{*}{ Locr2-hat } & $-0.0003^{* * *}$ & $-0.0001^{* * *}$ & $-0.00002^{* *}$ & $-0.00001^{* *}$ \\
\hline & $(0.00001)$ & $(0.00003)$ & $(-1.393)$ & $(-0.325)$ \\
\hline \multirow[t]{2}{*}{ Star-hat } & $0.202^{* * *}$ & $-0.069^{* * *}$ & $0.026^{* *}$ & $0.008^{* *}$ \\
\hline & $(0.002)$ & $(0.006)$ & $(8.104)$ & $(2.856)$ \\
\hline \multirow[t]{2}{*}{ Star2-hat } & $-0.003^{* * *}$ & $-0.0002^{*}$ & $-0.001^{* *}$ & $-0.0002^{* *}$ \\
\hline & $(0.0001)$ & $(0.0001)$ & $(-6.431)$ & $(-1.079)$ \\
\hline \multirow[t]{2}{*}{ Fedr-hat } & $2.524^{* * *}$ & $1.613^{* * *}$ & $0.038^{* *}$ & $0.013^{* *}$ \\
\hline & $(0.059)$ & $(0.104)$ & $(0.492)$ & $(0.176)$ \\
\hline \multirow[t]{2}{*}{ Fedr2-hat } & $-0.660^{* * *}$ & $-0.460^{* * *}$ & $-0.070^{* *}$ & $-0.045^{* *}$ \\
\hline & $(0.019)$ & $(0.029)$ & $(-1.465)$ & $(-0.823)$ \\
\hline \multirow[t]{2}{*}{ logSigma } & & $-1.125^{* *}$ & $0.069^{* *}$ & \\
\hline & & & $(-33.437)$ & $(11.677)$ \\
\hline \multicolumn{5}{|l|}{ Library Control } \\
\hline \multicolumn{5}{|l|}{ State Control } \\
\hline County FE & $\sqrt{ }$ & $\sqrt{ }$ & & \\
\hline State FE & & $\sqrt{ }$ & & $\sqrt{ }$ \\
\hline Library FE & & $\sqrt{ }$ & & \\
\hline Year FE & $\sqrt{ }$ & $\sqrt{ }$ & & $\sqrt{ }$ \\
\hline Observations & 119,123 & 119,123 & 128,729 & 128,729 \\
\hline $\mathrm{R} 2$ & 0.679 & 0.836 & & \\
\hline Adjusted R2 & 0.674 & 0.819 & & \\
\hline Stage1 F-Stat & $18450^{* * *}$ & $163^{* * *}$ & & \\
\hline
\end{tabular}

Notes: ${ }^{*} \mathrm{p}<0.1 ;{ }^{* *} \mathrm{p}<0.05 ;{ }^{* * *} \mathrm{p}<0.01$. For models 3 A and 4 A (Tobit estimations) we have t-stat in parenthesis. The Studentized $95 \%$ confidence intervals for model $3 \mathrm{~A}$ is $(0.0285,0.0425)$ and for model $4 \mathrm{~A}$ is $(-0.0128,-0.0363)$ 
Table 6.3: Results

\begin{tabular}{|c|c|c|c|}
\hline & \multicolumn{3}{|c|}{ Dependent variable: Donation } \\
\hline & $(1 \mathrm{~B})$ & $(2 \mathrm{~B})$ & $(3 \mathrm{~B})$ \\
\hline \multirow[t]{2}{*}{ Locr-hat } & $0.116^{* * *}$ & 0.041 & -0.228 \\
\hline & $(0.034)$ & $(0.082)$ & $(0.161)$ \\
\hline \multirow[t]{2}{*}{ Locr2-hat } & $-0.001^{* *}$ & 0.001 & 0.002 \\
\hline & $(0.0004)$ & $(0.001)$ & $(0.002)$ \\
\hline \multirow[t]{2}{*}{ Star-hat } & $-0.197^{* *}$ & $-0.695^{* *}$ & 0.116 \\
\hline & $(0.078)$ & $(0.329)$ & $(0.270)$ \\
\hline \multirow[t]{2}{*}{ Star2-hat } & $0.008^{* * *}$ & $0.022^{* *}$ & -0.005 \\
\hline & $(0.002)$ & $(0.009)$ & $(0.005)$ \\
\hline \multirow[t]{2}{*}{ Fedr-hat } & 2.132 & 2.086 & $11.779^{* * *}$ \\
\hline & $(4.474)$ & $(4.080)$ & $(4.339)$ \\
\hline \multirow[t]{2}{*}{ Fedr2-hat } & -0.566 & -0.311 & $-3.322^{* * *}$ \\
\hline & $(1.358)$ & $(1.339)$ & $(1.214)$ \\
\hline \multicolumn{4}{|l|}{ Library Control } \\
\hline \multicolumn{4}{|l|}{ State Control } \\
\hline \multicolumn{4}{|l|}{ County FE } \\
\hline State FE & & $\sqrt{ }$ & $\sqrt{ }$ \\
\hline \multicolumn{4}{|l|}{ Library FE } \\
\hline Year FE & $\sqrt{ }$ & $\sqrt{ }$ & $\sqrt{ }$ \\
\hline Observations & 128,729 & 128,729 & 128,729 \\
\hline $\mathrm{R} 2$ & 0.534 & 0.363 & 0.389 \\
\hline Adjusted R2 & 0.528 & 0.363 & 0.329 \\
\hline Stage1 F-Stat & $9.684^{* * *}$ & 1.631 & $2.656^{* *}$ \\
\hline
\end{tabular}

Notes: ${ }^{*} \mathrm{p}<0.1 ;{ }^{* *} \mathrm{p}<0.05 ;{ }^{* * *} \mathrm{p}<0.01 . \quad$ Instrument:

FEMA, SNAP, Politics 
Amir B. Ferreira Neto

\subsection{Appendix to Chapter 4}

Table 6.4: Average TE by Library

\begin{tabular}{|c|c|c|c|c|c|}
\hline Name & Gov & AvgTE & Name & Gov & AvgTE \\
\hline Alderson & CI & 0.90 & Moundsville-Marshall County & MJ & 1.00 \\
\hline Belington & CI & 0.93 & Mountaintop & MJ & 0.66 \\
\hline Bolivar-Harpers Ferry & MJ & 0.84 & New Martinsville & $\mathrm{CI}$ & 0.71 \\
\hline Boone-Madison & MJ & 0.88 & Nitro & $\mathrm{CI}$ & 0.95 \\
\hline Bridgeport & $\mathrm{CI}$ & 1.00 & Nutter Fort & $\mathrm{CI}$ & 0.45 \\
\hline Brooke County & $\mathrm{CO}$ & 0.87 & Ohio County & $\mathrm{CO}$ & 1.00 \\
\hline Buffalo Creek Memorial & CI & 0.85 & Paden City & CI & 0.77 \\
\hline Burnsville & $\mathrm{CI}$ & 0.85 & Parkersburg/Wood Co. & MJ & 1.00 \\
\hline Cabell County & MJ & 1.00 & Paw Paw & CI & 0.75 \\
\hline Calhoun County & $\mathrm{CO}$ & 0.80 & Pendleton County & $\mathrm{CO}$ & 0.89 \\
\hline Capon Bridge & CI & 0.75 & Peterstown & CI & 0.91 \\
\hline Chapmanville & CI & 0.85 & Philippi & $\mathrm{CI}$ & 0.79 \\
\hline Charles W. Gibson & CI & 1.00 & Piedmont & $\mathrm{CI}$ & 0.94 \\
\hline Clarksburg-Harrison Co. & MJ & 0.99 & Pine Grove & CI & 0.83 \\
\hline Clay County & $\mathrm{CO}$ & 0.91 & Pioneer Memorial & $\mathrm{CO}$ & 0.85 \\
\hline Cowen & $\mathrm{CI}$ & 0.92 & Pleasants County & $\mathrm{CO}$ & 0.71 \\
\hline Craft Memorial & $\mathrm{CI}$ & 1.00 & Pocahontas County Free & $\mathrm{CO}$ & 1.00 \\
\hline Craigsville & $\mathrm{CO}$ & 0.97 & Princeton & $\mathrm{CI}$ & 0.95 \\
\hline Doddridge County & $\mathrm{CO}$ & 0.50 & Putnam County & $\mathrm{CO}$ & 1.00 \\
\hline Dora Bee Woodyard Memorial & $\mathrm{CO}$ & 0.51 & Rainelle & CI & 0.86 \\
\hline Elkins-Randolph & MJ & 1.00 & Raleigh County & MJ & 1.00 \\
\hline Fayette County & $\mathrm{CO}$ & 1.00 & Richwood & CI & 0.75 \\
\hline Five Rivers & $\mathrm{CI}$ & 0.56 & Ritchie County & $\mathrm{CO}$ & 1.00 \\
\hline Gassaway & CI & 0.92 & Roane County & $\mathrm{CO}$ & 1.00 \\
\hline Gilmer & CI & 0.76 & Ronceverte & CI & 0.68 \\
\hline Grant County & $\mathrm{CO}$ & 0.54 & Rupert & CI & 0.89 \\
\hline Greenbrier County & CI & 1.00 & Shepherdstown & $\mathrm{CI}$ & 1.00 \\
\hline Hamlin-Lincoln County & $\mathrm{CI}$ & 0.92 & Sistersville & MJ & 0.82 \\
\hline Hampshire County & $\mathrm{CO}$ & 1.00 & South Charleston & CI & 1.00 \\
\hline Hardy County & MJ & 0.76 & South Jefferson & $\mathrm{CO}$ & 0.99 \\
\hline Helvetia & $\mathrm{CO}$ & 0.90 & Southern Area & CI & 0.90 \\
\hline Hundred & MJ & 1.00 & Summers County & $\mathrm{CO}$ & 0.88 \\
\hline Jackson County & $\mathrm{CO}$ & 1.00 & Summersville & $\mathrm{CI}$ & 0.80 \\
\hline Kanawha County & $\mathrm{CO}$ & 1.00 & Sutton & CI & 0.89 \\
\hline Keyser-Mineral County & MJ & 0.94 & Swaney Memorial & $\mathrm{CI}$ & 0.57 \\
\hline Kingwood & $\mathrm{CI}$ & 0.90 & Taylor County & MJ & 0.86 \\
\hline Logan Area & $\mathrm{CO}$ & 0.83 & Terra Alta & $\mathrm{CI}$ & 1.00 \\
\hline Louis Bennett & $\mathrm{CO}$ & 1.00 & Tygart Valley & CI & 0.61 \\
\hline Lowe & $\mathrm{CI}$ & 0.57 & Tyler County & $\mathrm{CI}$ & 0.73 \\
\hline Lynn Murray Memorial & $\mathrm{CI}$ & 0.87 & Upshur County & $\mathrm{CO}$ & 0.84 \\
\hline Marion County & MJ & 1.00 & Valley Head & $\mathrm{CO}$ & 0.79 \\
\hline Martinsburg-Berkeley Co. & $\mathrm{CI}$ & 0.94 & Vienna & MJ & 0.86 \\
\hline Mary H. Weir & CI & 0.38 & War & CI & 0.94 \\
\hline Mason County & $\mathrm{CO}$ & 0.82 & Wayne County & $\mathrm{CO}$ & 1.00 \\
\hline Mcdowell & $\mathrm{CI}$ & 1.00 & Webster-Addison & MJ & 0.75 \\
\hline Mingo County & $\mathrm{CO}$ & 1.00 & White Sulphur Springs & CI & 0.83 \\
\hline Monroe County & $\mathrm{CO}$ & 0.84 & Williamson & CI & 0.55 \\
\hline Morgan County & $\mathrm{CO}$ & 0.72 & Wyoming County & $\mathrm{CO}$ & 1.00 \\
\hline Morgantown & $\mathrm{CI}$ & 1.00 & & & \\
\hline
\end{tabular}




\section{Bibliography}

Aabø, S. (2005). Valuing the Benefits of Public Libraries. Information Economics and Policy, $17: 175-198$.

Aabø, S. and Strand, J. (2004). Public Library Valuation, Nonuse Values, and Altruistic Motivations. Library and Information Science Research, 26(3):351-372.

Abrams, B. A. and Schmitz, M. D. (1984). The Crowding-Out Effect of Governmental Transfers on Private Charitable Contributions: Cross-Section Evidence. National Tax Journal, 37(4):563-568.

Afonso, A. and Aubyn, M. S. (2005). Non-Parametric Approaches to Education and Health Efficiency in OECD Countries. Journal of Applied Economics, 8(2):227-246.

Afonso, A. and Fernandes, S. (2006). Measuring Local Government Spending Efficiency: Evidence for the Lisbon Region. Regional Studies, 1:39-53.

Afonso, A., Schuknecht, L., and Tanzi, V. (2005). Public Sector Efficiency: An International Comparison. Public Choice, 123(3):321-347.

American Library Association (2010). A Perfect Storm Brewing: Budget Cuts Threaten Library Services at Time of Increased Demand. Accessed on 10 June 2015.

American Library Association (2015). Number of Libraries in the United States. Accessed on September 20, 2015.

American Library Association (2018). Types of Library Jobs. Accessed August 28, 2018.

Andreoni, J. (1989). Giving with Impure Altruism: Applications to Charity and Ricardian Equivalence. Journal of Political Economy, 97(6):1447-1458.

Andreoni, J. (1990). Impure Altruism and Donations to Public Goods: A Theory of WarmGlow Giving. The Economic Journal, 100:464-477.

Andreoni, J. and Scholz, J. K. (1998). An Econometric Analysis of Charitable Giving with Interdependent Preferences. Economic Inquiry, 36(3):410-428. 
Angrist, J. D. and Pischke, J.-S. (2009). Mostly Harmless Econometrics: An Empiricist's Companion. Princeton University Press.

Appalachian Regional Commission (2018). The Appalachian Region. Accessed July 30, 2018.

Arbia, G. (1988). Spatial Data Configuration in Then Statistical Analysis of Regional Economic and Related Problems. Kluwer Academic Publishers, Dordrecht.

Ashenfelter, O. (1978). Estimating the Effect of Training Programs on Earnings. The Review of Economics and Statistics, 60(1):47-57.

Bailey, N., Holly, S., and Pesaran, M. (2016). A Two-Stage Approach to Spatio-Temporal Analysis with Strong and Weak Cross-Sectional Dependence. Journal of Applied Econometrics, 31(1):249-280.

Bakija, J. M., Gale, W. G., and Slemrod, J. B. (2003). Charitable Bequests and Taxes on Inheritances and Estates: Aggregate Evidence from across States and Time. The American Economic Review, 93(2):366-370.

Baumol, W. J. and Matityahu, M. (1973). Economic of Academic Libraries. American Council of Education, Washington, DC.

Bekkers, R. and Wiepking, P. (2011). A Literature Review of Empirical Studies of Philanthropy: Eight Mechanisms that Drive Charitable Giving. Nonprofit and Voluntary Sector Quarterly, 40(5):924-973.

Beranek, W., Kamerschen, D. R., and Timberlake, R. H. (2010). Charitable Donations and the Estate Tax: A Tale of Two Hypotheses. American Journal of Economics and Sociology, 69(3):1054-1078.

Bertot, J., McDermott, A., Lincoln, R., Real, B., and Peterson, K. (2012). 2011-2012 Public Library Funding \& Technology Access Survey: Survey Findings \& Report. Technical report, Information Policy \& Access Center, University of Maryland College Park, College Park, MD. 
Betts, J. R. (1995). Does School Quality Matter? Evidence from the National Longitudinal Survey of Youth. The Review of Economics and Statistics, 77(2):231-50.

Betz, M. R. and Partridge, M. D. (2012). Country Road Take Me Home: Migration Patterns in Appalachian America and Place-based Policy. International Regional Science Review, 36(3):267-295.

Bhatt, R. (2010). The impact of Public Library Use on Reading, Television, and Academic Outcomes. Journal of Urban Economics, 68(2):148-166.

Black, D., Kolesnikova, N., and Taylor, L. J. (2014). Why do so Few Women Work in New York (and so Many in Minneapolis)? Labor Supply of Married Women Across US Cities. Journal of Urban Economics, 79(C):59-71.

Blanchard, O. and Katz, L. (1992). Regional Evolutions. Brookings Papers on Economic Activity, 23(1):1-76.

Blau, R. (2011). Funding Cuts Closing Book on All 62 branches in Queens Library. Daily News.

Bogetoft, P. and Otto, L. (2010). Benchmarking with DEA, SFA, and R. Springer.

Bollinger, C., Ziliak, J. P., and Troske, K. R. (2011). Down from the Mountain: Skill Upgrading and Wages in Appalachia. Journal of Labor Economics, 29(4):819-857.

Bookstein, A. (1981). An Economic Model of Library Service. The Library Quarterly: Information, Community, Policy, 51(4):410-428.

Borgonovi, F. (2006). Do Public Grants to American Theatres Crowd-out Private Donations? Public Choice, 126(3/4):429-451.

Borgonovi, F. and O'Hare, M. (2004). The Impact of the National Endowment for the Arts in the United States: Institutional and Sectoral Effects on Private Funding. Journal of Cultural Economics, 28(1):21-36. 
Briant, A., Combes, P.-P., and Lafourcade, M. (2010). Dots to Boxes: Do the Size and Shape of Spatial Units Jeopardize Economic Geography Estimations? Journal of Urban Economics, 67(3):287-302.

Brooks, A. C. (2003). Do Government Subsidies to Nonprofits Crowd Out Donations or Donors? Public Finance Review, 31(2):166-179.

Brown, A. J. and Koettl, J. (2015). Active Labor Market Programs - Employment Gain or Fiscal Drain? IZA Journal of Labor Economics, 4(12):1-36.

Brown, E. and Lankford, H. (1992). Gifts of Money and Gifts of Time Estimating the Effects of Tax Prices and Available Time. Journal of Public Economics, 47(3):321-341.

Cajner, T., Radler, T., Ratner, D., and Vidangos, I. (2017). Racial Gaps in Labor Market Outcomes in the Last Four Decades and over the Business Cycle. Finance and Economics Discussion Series 2017-071. Washington: Board of Governors of the Federal Reserve System, DOI:10.17016/FEDS.2017.071.

Card, D., Kluve, J., and Weber, A. (2010). Active Labour Market Policy Evaluations: A Meta-Analysis. The Economic Journal, 120(548):F452-F477.

Card, D., Kluve, J., and Weber, A. (2018). What Works? A Meta Analysis of Recent Active Labor Market Program Evaluations. Journal of the European Economic Association, $16(3): 894-931$

Cleaver, J. (2015). New Hartford Library Grapples with Budget Cuts. Utica Observer Dispatch.

Clotfelter, C. T. (1980). Tax Incentives and Charitable Giving: Evidence from a Panel of Taxpayers. Journal of Public Economics, 13(3):319-340.

College Board (2017). College Education Linked to Higher Pay, Job Security, Healthier Behaviors and More Civic Involvement: New College Board Report. Press Release. Accessed July 30, 2018. 
Collins, A. and Halverson, R. (2010). The Second Educational Revolution: Rethinking Education in the Age of Technology. Journal of Computer Assisted Learning, 26(1):1827.

Cooper, W., Seiford, L., and Tone, K. (2007). Data Envelopment Analysis: A Comprehensive Text with Models, Applications, References and DEA-Solver Software. Springer, New York, 2nd edition.

Cunningham, S. (2018). Causal Inference: The Mixtape (V.1.7). tufte-latex.googlecode.com.

Davis, A. (2015). Looming Crisis: Several Local Libraries Preparing for Cuts if State Budget isn't Passed. The Bradford Era, December 2.

de Wit, A. and Bekkers, R. (2017). Government Support and Charitable Donations: A MetaSnalysis of the Crowding-out Hypothesis. Journal of Public Administration Research and Theory, 27(2):301-319.

DeBoer, L. (1992). Economies of Scale and Input Substitution in Public Libraries. Journal of Urban Economics, 32(2):257-268.

Detotto, C. and McCannon, B. C. (2017). Economic Freedom and Public, Non-Market Institutions: Evidence from Criminal Prosecution. Economics of Governance, 18(2):1-22.

Dixon, J. and Gillis, S. (2017). Doing Fine(s)? Fines \& Fees. Library Journal.

Dorsey, S. (1991). The Strange Case of the Missing West Virginia Labor Force. Growth and Change, 22(3):49-65.

Dubner, S. J. (2007). If Public Libraries Didn't Exist, Could You Start One Today? Accessed on July 21, 2018.

Dunham, K., Goger, A., Henderson-Frakes, J., and Tucker, N. (2005). Workforce Development in Rural Areas: Changes in Access, Service Delivery and Partnerships. Technical report, U.S. Department of Labor. Employment and Training Administration Occasional Paper 2005-07. 
Fallows, D. (2014). What a Library Levy Means to a West Virginia Town. The Atlantic.

Farber, H. S. and Gibbons, R. (1996). Learning and Wage Dynamics. The Quarterly Journal of Economics, 111(4):1007-1047.

Feldstein, K. F. (1976). The Economics of Public Libraries. PhD thesis, Massachusetts Institute of Technology.

Feldstein, M. and Taylor, A. (1976). The Income Tax and Charitable Contributions. Econometrica, 44(6):1201-1222.

Ferreira Neto, A. B. (2018). Charity and Public Libraries: Does Government Funding Crowd Out Donations? Journal of Cultural Economics, 42(4):525--542. DOI: 10.1007/s10824018-9318-4.

Ferreira Neto, A. B. and Hall, J. (2018). Economies of Scale and Governance of Library Systems: Evidence from West Virginia. Technical report.

Fischel, W. A. (2007). The Congruence of American School Districts with Other Local Government Boundaries: A Google-Earth Exploration. Dartmout College Economics Working Paper, Hanover, NH.

Flood, S., King, M., Ruggles, S., and Warren, J. R. (2015). Integrated Public Use Microdata Series, Current Population Survey: Version 4.0. [Machine-readable database]. Minneapolis: University of Minnesota.

Fujiwara, D., Lawton, R. N., and Mourato, S. (2017). The Health and Wellbeing Benefits of Public Libraries. Economia della Cultura, (2):203-212.

Gautier, P., Muller, P., van der Klaauw, B., Rosholm, M., and Svarer, M. (2018). Estimating equilibrium effects of job search assistance. Journal of Labor Economics, 36(4):1073-1125.

Getz, M. (1980). Public Libraries: An Economic View. The Johns Hopkins University Pres.

Goddard, H. C. (1970). A Study in the Theory and Measurement of Benefits and Costs in the Public Library. PhD thesis, Indiana University. 
Goulding, A., editor (2006). Public Libraries in the 21st Century: Defining Services and Debating the Future. Ashgate Publishing Company.

Green, G. P., Galetto, V., and Haines, A. (2003). Collaborative Job Training in Rural Areas. Journal of Research in Rural Education, 18(2):78-85.

Greenberg, D. H., Michalopoulos, C., and Robins, P. K. (2003). A Meta-Analysis of Government-Sponsored Training Programs. Industrial and Labor Relations Review, $57(1): 31-53$.

Gruber, J. and Hungerman, D. M. (2007). Faith-based Charity and Crowd-out During the Great Depression. Journal of Public Economics, 91:1043--1069.

Haaga, J. (2004). Demographic and Socioeconomic Change in Appalachia. Technical report, Population Reference Bureau.

Hall, J. C. (2007). Local School Finance and Productive Efficiency: Evidence from Ohio. Atlantic Economic Journal, 35:289-301.

Halleck Vega, S. and Elhorst, J. (2016). A Regional Unemployment Model Simultaneously Accounting for Serial Dynamics, Spatial Dependence and Common Factors. Regional Science and Urban Economics, 60(C):85-95.

Hammond, C. (2009). The Effect of Organisational Change on UK Public Library Efficiency. International Journal of Production Economics, 121(1):286-295.

Hammond, C. J. (1999). The Technology of Library Service Provision: A Cost Function Analysis of Public Library Systems in the United Kingdom. Information Economics and Policy, 11:271--295.

Hammond, C. J. (2002). Efficiency in the Provision of Public Services: A Data Envelopment Analysis of UK Public Library Systems. Applied Economics, 34:649-657.

Hampton, K. N. (2018). Device Divides, Mobile vs Wired Broadband: The Social Implications for Urban and Rural Communities. vailable at SSRN: https://ssrn.com/abstract $=3139753$. 
Hardina, D. (1990). The Effect of Funding Sources on Client Access to Services. Administration in Social Work.

Hashimoto, M. and Raisian, J. (1985). Employment Tenure and Earnings Profiles in Japan and the United States. The American Economic Review, 75(4):721-735.

Heckman, J. J., Lalonde, R. J., and Smith, J. A. (1999). The Economics and Econometrics of Active Labor Market Programs. volume 3 of Handbook of Labor Economics, pages 1865-2097. Elsevier.

Hemmeter, J. A. (2006). Estimating Public Library Efficiency Using Stochastic Frontiers. Public Finance Review, 34(3):328-348.

Hipple, S. F. (2016). Labor Force Participation: What has Happened Since the Peak? Monthly Labor Review.

Hodge, M. M. and Piccolo, R. F. (2005). Funding source, board involvement techniques, and financial vulnerability in nonprofit organizations: A test of resource dependence. Nonprofit Management and Leadership.

Horrigan, J. (2015). Libraries at the Crossroads. Pew Research Center.

Howard Fleeter \& Associates (2017). Analysis of Property Tax Levies for Library Purposes . Technical report.

Hoxby, C. M. (1999). The Productivity of Schools and Other Local Public Goods Producers. Journal of Public Economics, 74(1):1-30.

Hrin, E. (2018). Library Levy Up for a Vote. Times West Virginian.

Hunt, K., editor (2017). Library Programs and Services for New Adults. Libraries Unlimited.

Ichimura, H. and Taber, C. (2001). Propensity-Score Matching with Instrumental Variables. American Economic Review, 91(2):119-124.

Isserman, A. M. and Rephann, T. J. (1993). Geographical and Gender Differences in Labor Force Participation: Is there and Appalachian Effect? Growth and Change, 24:539-578. 
Jackson, R. (1974). Evidence on Erosion of a Resource Due to Population Growth: Case of the Public Library. Land Economics, 50(1):70-75.

James, R. N. (2008). Health, Wealth, and Charitable Estate Planning: A Longitudinal Examination of Testamentary Charitable Giving Plans. Nonprofit and Voluntary Sector Quarterly, 38(6):1026-1043.

Jerrard, J. (2009). Crisis In Employment : A Librarian's Guide to Helping Job Seekers. American Library Association.

Kahn, M. (2009). Cities, Economic Development, and the Role of Place-Based Polices: Lessons for Appalachia. University of Kentucky Center for Poverty Research Discussion Paper Series, DP2009-12.

Katz, S. N. (2006). Philantropy, volume 1 of Handbook of the Economics of Art and Culture, chapter 37, pages 1299-1321. Elsevier. DOI: 10.1016/S1574-0676(06)01037-4.

Kelley, A. (2015). State Budget Impasse Forces Library Cuts. WNEP.com, December 8.

Khanna, J., Posnett, J., and Sandier, T. (1995). Charity Donations in the UK: New Evidence Based on Panel Data. Journal of Public Economics, 56:257-272.

Kluve, J. (2010). The Effectiveness of European Active Labor Market Programs. Labour Economics, 17:904-918.

Knight, D. M. and Nourse, E. S., editors (1969). Libraries at Large: Tradition, Innovation and The National Interest. R.R. Bowker Company.

Koenker, R. W. and Bassett, G. W. (1978). Regression Quantiles. Econometrica, 46:33-50.

LaLonde, R. J. (2003). Employment and Training Programs. In Moffitt, R. A., editor, MeansTested Transfer Programs in the United States, pages 517-585. University of Chicago Press.

LeSage, J. P. and Pace, R. K. (2014a). The Biggest Myth in Spatial Econometrics. Econometrics, 2:217-249. 
LeSage, J. P. and Pace, R. K. (2014b). What Regional Scientists Need to Know About Spatial Econometrics. The Review of Regional Studies, 44:13-32.

Liu, L. G. (2004). The Contribution of Public Libraries to Countries' Economic Productivity: A Path Analysis. Library Review, 53(9):435-441.

Locher, L. (2005). Public Library Fees in Germany. Journal of Cultural Economics, 29:313324.

Maddison, D. (2004). Causality and Museum Subsidies. Journal of Cultural Economics, 28(2):89-108.

McCallum, I. and Quinn, S. (2004). Valuing Libraries. The Australian Library Journal, 53(1):55-69.

Millo, G. and Piras, G. (2012). splm: Spatial Panel Data Models in R. Journal of Statistical Software, 047(1):1-38.

Mourdoukoutas, P. (2018). Twitter Moment. Retrieved from: https://twitter.com/PMourdoukoutas/status/1020654721655242754.

Noble, K. B. (1988). Library as Day Care: New Curbs and Concerns. The New York Times.

Okten, C. and Weisbrod, B. A. (2000). Determinants of Donations in Private Nonprofit Markets. Journal of Public Economics, 75:255-272.

Ostrom, V., Tiebout, C. M., and Warren, R. (1961). The Organization of Government in Metropolitan Areas: A Theoretical Inquiry. American Political Science Review, 55(4):831842 .

Paqué, K.-H. (1982). Do Public Transfers "Crowd Out" Private Charitable Giving? Some Econometric Evidence for the Federal Republic of Germany. Kiel Working Papers, No. 152.

Parrish, T. N. (2013). Libraries Double as Unofficial Day Cares. Trib Total Media. 
Partridge, M. (2001). Exploring the Canadian-U.S. Unemployment and Nonemployment Rate Gaps: Are There Lessons for Both Countries? Journal of Regional Science, $41(4): 701-734$.

Partridge, M. D. and Rickman, D. S. (1997). The Dispersion of US State Unemployment Rates: The Role of Market and Non-market Equilibrium Factors. Regional Studies, $31(6): 593-606$.

Patacchini, E. and Zenou, Y. (2007). Spatial Dependence in Local Unemployment Rates. Journal of Economic Geography, 7(2):169-191.

Payne, A. A. (1998). Does the Government Crowd-out Private Donations? New Evidence from a Sample of Non-profit Firms. Journal of Public Economics, 69:323-345.

Peloza, J. and Steel, P. (2005). The Price Elasticities of Charitable Contributions: A MetaAnalysis. Journal of Public Policy \& Marketing, 24(2):260-272.

Pesaran, M. (2006). Estimation and Inference in Large Heterogeneous Panels with a Multifactor Error Structure. Econometrica, 74(4):967-1012.

Pew Research Center (2013a). How Americans Value Public Libraries in Their Communities. Technical report.

Pew Research Center (2013b). Library Services in the Digital Age. Technical report.

Pew Research Center (2013c). Parents, Children, Libraries, and Reading. Technical report.

Pew Research Center (2014). From Distant Admirers to Library Lovers: A Typology of Public Library Engagement in America. Technical report.

Pfister, R. L. and Milliman, J. W. (1970). Economic Aspects of Library Service in Indiana. Technical report, Indiana University, Bloomington. Graduate Library School. Indiana Library Studies Report 7.

Pollard, K. and Jacobsen, L. A. (2017). The Appalachian Region: A Data Overview from the 2011-2015 American Community Survey. Technical report, Population Reference Bureau. 
Rainie, L. (2016). Libraries and Learning. Pew Research Center.

Real, B. and Rose, R. N. (2017). Rural Libraries in the United States: Recent Strides, Future Possibilities, and Meeting Community Needs. American Library Association.

Reece, W. S. (1979). Charitable Contributions: New Evidence on Household Behavior. The American Economic Review, 69(1):142-151.

Reichmann, G. and Sommersguter-Reichmann, M. (2006). University Library Benchmarking: An International Comparison Using DEA. International Journal Production Economics, 100:131-147.

Reichmann, G. and Sommersguter-Reichmann, M. (2010). Efficiency Measures and Productivity Indexes in the Context of University Library Benchmarking. Applied Economics, 42:311-323.

Rosa, K. (2014). Research and Statistics on Libraries and Librarianship in 2013. Library Research and Statistics.

Sayago-Gomez, J.-T., Piras, G., Jackson, R., and Lacombe, D. (2018). Impact Evaluation of Investments in the Appalachian Region: A Reappraisal. International Regional Science Review, 41(6):601-629.

Sharma, K. R., Leung, P., and Zane, L. (1999). Performance Measurement of Hawaii State Public Libraries: An Application of Data Envelopment Analysis. Agricultural and Resource Economics Review, 28(2).

Sheppard, S., Oehler, K., and Benjamin, B. (2006). Buying Into Bohemia: the Impact of Cultural Amenities on Property Values. Center for Creative Community Development.

Simmons, W. O. and Emanuele, R. (2004). Does Governemnt Spending Crowd Out Donations of Time and Money? Public Finance Review, 32(5):498-511.

Smith, L. and Rivera, E. (2004). Turning Librarians Into Babysitters. The Washington Post. 
Smith, P. C. and Street, A. (2005). Measuring the Efficiency of Public Services: The Limits of Analysis. Journal of the Royal Statistical Society Series A, 168(2):401-417.

Smith, R. (2015). Cedar Rapids Library Board Hears First Suggestion on Budget Cuts. The Gazette, November 6.

Smith, T. M. (2003). Raising the Barre: The Geographic, Financial, and Economic Trends of Nonprofit Dance Companies. Technical report, National Endowment for the Arts. Research Division Report N.44.

Spokane Public Library (2017). Measure No. 1 Library Operations Levy. Technical report.

Steinberg, R. (1991). Does Governemnt Spending Crowd Out Donations? Interpreting the Evidence. Annals of Public and Cooperative Economics, 62(4):591-612.

Stenberg, P., Morehart, M., Vogel, S., Cromartie, J., Breneman, V., and Brown, D. (2009). Broadband Internet's Value for Rural America. Technical Report Economic Research Report Number 78.

Stephens, H. and Partridge, M. (2011). Do Entrepreneurs Enhance Economic Growth in Lagging Regions? Growth and Change, 42(4):431-465.

Stephens, H. M. and Deskins, J. (2018). Economic Distress and Labor Market Participation. American Journal of Agricultural Economics. DOI: 10.1093/ajae/aay065.

Stepleton, I. (2015). Library Will Keep Staff, Hours Intact Despite Cuts. Ribbon Commonwealth Press.

Stine, W. F. (2008). An Empirical Analysis of the Effect of Volunteer Labor on Public Library Employment. Managerial Decision Economics, 29:525-538.

Stock, J. H. and Yogo, M. (2005). Testing for Weak Instruments in Linear IV Regressions. In Andrews, D. W. and Stock, J. H., editors, Identification and Inference for Econometric Models, pages 80--108. Cambridge University Press. 
Stratton, P. J. (1976). Public Libraries: Their Structure, Use and Cost of Service Provision. An Analysis with Special Emphasis on Public Libraries in Illinois. PhD thesis, Northern Illinois University.

Swan, D., Grimes, J., and Owens, T. (2013). The State of Small and Rural Libraries in the United States. Technical Report Research Brief series, no. 5 (IMLS-2013-RB-05), Washington, DC.

The Institute of Museum and Libraries Services (2014a). Public Libraries in the United States Fiscal Year 2012: Fast Facts.

The Institute of Museum and Libraries Services (2014b). Public Libraries in the United States Survey: FY 2012. Washington, DC.

The Institute of Museum and Libraries Services (2015). FY 2013 PLS: Supplementary Tables-Tables 21-31A. Washington, DC.

The Institute of Museum and Libraries Services (2016). Public Libraries in the United States Fiscal Year 2014. Washington, DC.

The Institute of Museum and Library Services (2018). Public Libraries Survey. Accessed on July 18, 2018.

Tiebout, C. M. and Willis, R. J. (1965). The Public Nature of Libraries. In Conant, R. W., editor, The Public Library and the City, pages 94-101. M.I.T.. Press.

Vitaliano, D. F. (1997). X-Inefficiency in the Public Sector: The Case of Libraries. Public Finance Review, 25(6):629-643.

Vitaliano, D. F. (1998). Assessing Public Library Efficiency Using Data Envelopment Analysis. Annals of Public and Cooperative Economics, 69(1):107-122.

Walker, A. (2017). Twitter Moment. Retrieved from: https://twitter.com/andrejpwalker/status/922628584619085824. 
Warburton, B. (2013). Libraries Around the Country Under Budget Pressure. Library Journal.

West Virginia Library Commission (2013). Public Library Funding Review. West Virginia Library Commission, Charleston.

Whitener, L. A. (1991). The JOBS Program and Rural Areas. Rural Development Perspectives, $7(2): 21-26$.

Wiegand, W. A. (2015). Part of Our Lives - A People's History of the American Public Library. Oxford University Press.

Willes, S. (2016). Monongalia County Voters Favor 4 of 6 Proposed Levies. WAJR.com, May 11.

Witte, K. D. and Geys, B. (2011). Evaluating Efficient Public Good Provision: Theory and Evidence from a Generalised Conditional Efficiency Model for Public Libraries. Journal of Urban Economics, 69(3):319-327.

Woods, D. (2015). Bridgeton Proposes to Close Cumberland County Library. New Jersey.

Wooldridge, J. M. (2016). Should Instrumental Variables be Used as Matching Variables? Research in Economics, 70(2):232 - 237.

Worthington, A. (1999). Performance Indicators and Efficiency Measurement in Public Libraries. Australian Economic Review, 32(1):31-42.

WV Gazette (2016). County election results from around West Virginia. WV Gazette, May 10.

Yermack, D. (2017). Donor Governance and Financial Management in Prominent US Art Museums. Journal of Cultural Economics, 41(3):215-235.

Young, R. (1973). An Exploratory Analysis of Demand for the Public Library Lending Services. Applied Economics, 5:119-132. 
Zhu, M. and Peyrache, A. (2017). The Quality and Efficiency of Public Service Delivery in the UK and China. Regional Studies, 2(51):285-296. 